\title{
20. PETROLOGY AND GEOCHEMISTRY OF VOLCANIC ROCKS, DSDP LEG 55, EMPEROR SEAMOUNT CHAIN
}

\author{
R. James Kirkpatrick, Department of Geology, University of Illinois, Urbana, Illinois \\ David A. Clague, Department of Geology, Middlebury College, Middlebury, Vermont \\ and \\ Walter Freisen, U. S. Geological Survey, Menlo Park, California
}

\section{INTRODUCTION}

The volcanic rocks recovered on Deep Sea drilling Project Leg 55 from the central Emperor Seamount chain in the northwest Pacific were all erupted subaerially, and include tholeiitic basalts, tholeiitic picrites alkali basalts, and hawaiites similar to those found in the southern Emperor chain and the Hawaiian chain. These rocks were recovered from three sites $(430,432$, and 433) on three different seamounts along the Emperor chain (Figure 1). The purposes of this paper are to present our post-cruise petrographic and geochemical data, to classify the rock types, to discuss the chemical stratigraphy of the volcanics, to discuss the petrogenetic relationships at each site, to discuss the variation in basalt composition along the chain, and to discuss the origin of linear island chain basalts. The shipboard petrographic and chemical data, coring and recovery information, and the flow by flow stratigraphy are presented in the appropriate site chapters (Leg 55 Scientific Party, this volume) and in the Introduction and Synthesis (Jackson et al., this volume). These chapters also present the rationale and operational history of Leg 55.

The modal petrographic data to be presented here were obtained using normal point-counting techniques. The chemical analyses were done in the USGS analytical laboratory in Menlo Park, California. Most were done using XRF techniques. A comparison of XRF and wet chemical analyses of four samples is presented in Table 1. The two kinds of analyses give similar results, except for $\mathrm{MgO}$, for which the XRF analyses are higher by about 0.2 weight per cent. Although no samples were analyzed both at Menlo Park and on board, the more numerous analyses done on board the Challenger also appear to be comparable to the USGS analyses, and all available analyses will be used here. Whole-rock electron microprobe analyses of fused glasses made from some of the same samples reported here are given by Bence et al. (this volume). Electron microprobe analyses of phenocryst and groundmass olivine, pyroxene, plagioclase, iron-titanium oxides, and chrome spinels are given by Clague et al. (this volume). Electron microprobe analyses of clay minerals in the samples dated by $\mathrm{K} / \mathrm{Ar}$ techniques are presented by Dalrymple et al. (this volume).

\section{SITE 430}

Site 430 was drilled into a lagoonal sediment pond near the center of Ōjin Seamount at $37^{\circ} 59.24^{\prime} \mathrm{N}, 170^{\circ}$

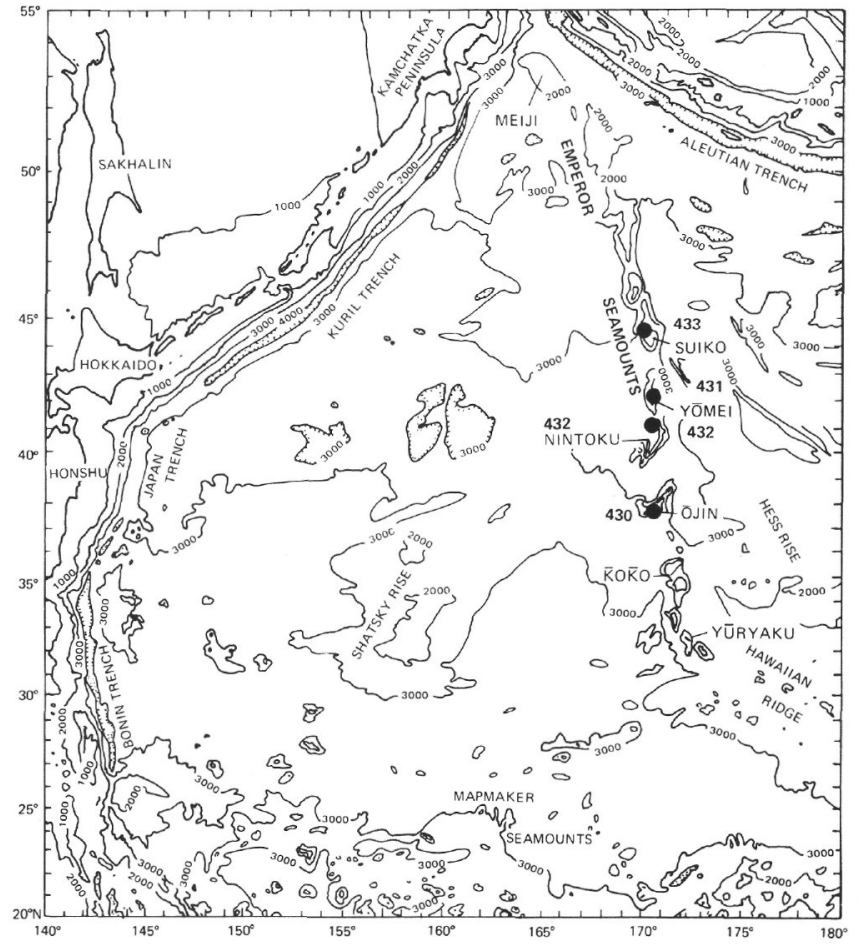

Figure 1. Locations of Leg 55 Sites.

TABLE 1

Comparison of Wet-Chemical and X-ray Fluorescence Analyses on Four Samples of Lava Flows Recovered on DSDP Leg 55.a

\begin{tabular}{|c|c|c|c|c|c|c|c|c|}
\hline \multirow{3}{*}{$\begin{array}{l}\text { Hole } \\
\text { Core-Section, } \\
\text { Interval (cm) } \\
\text { Type }\end{array}$} & \multicolumn{2}{|c|}{$430 \mathrm{~A}$} & \multicolumn{2}{|c|}{$433 \mathrm{~A}$} & \multicolumn{2}{|c|}{$433 \mathrm{C}$} & \multicolumn{2}{|c|}{$433 C$} \\
\hline & \multicolumn{2}{|c|}{$4-2,110-113$} & \multicolumn{2}{|c|}{$21-4,129-138$} & \multicolumn{2}{|c|}{$15-6,16-31$} & \multicolumn{2}{|c|}{$17-1,78-82$} \\
\hline & Wet & X-ray & Wet & $X$-ray & Wet & X-ray & Wet & X-ray \\
\hline $\mathrm{SiO}_{2}$ & 49.35 & 49.49 & 48.08 & 47.79 & 49.03 & 48.78 & 49.75 & 49.45 \\
\hline $\mathrm{Al}_{2} \mathrm{O}_{3}$ & 17.55 & 17.58 & 15.11 & 15.05 & 14.29 & 14.54 & 14.02 & 14.14 \\
\hline $\mathrm{FeO}$ & 12.62 & 12.51 & 13.95 & 14.01 & 12.97 & 13.00 & 13.05 & 13.10 \\
\hline $\mathrm{MgO}$ & 2.90 & 3.07 & 5.13 & 5.40 & 6.74 & 6.83 & 6.29 & 6.52 \\
\hline $\mathrm{CaO}$ & 6.17 & 6.10 & 9.36 & 9.48 & 10.64 & 10.59 & 10.70 & 10.67 \\
\hline $\mathrm{Na}_{2} \mathrm{O}$ & 4.63 & 4.48 & 3.61 & 3.60 & 2.95 & 2.96 & 2.83 & 2.88 \\
\hline $\mathrm{K}_{2} \mathrm{O}$ & 2.06 & 2.05 & 0.95 & 0.91 & 0.28 & 0.25 & 0.34 & 0.29 \\
\hline $\mathrm{TiO}_{2}$ & 3.31 & 3.32 & 3.19 & 3.23 & 2.64 & 2.61 & 2.55 & 2.51 \\
\hline $\mathrm{P}_{2} \mathrm{O}_{5}$ & 1.35 & 1.33 & 0.43 & 0.35 & 0.30 & 0.28 & 0.29 & 0.25 \\
\hline $\mathrm{MnO}$ & 0.06 & 0.07 & 0.19 & 0.18 & 0.17 & 0.16 & 0.19 & 0.19 \\
\hline Totals & 100.00 & 100.00 & 100.00 & 100.00 & 100.00 & 100.00 & 100.00 & 100.00 \\
\hline
\end{tabular}

${ }^{\mathrm{a}}$ The analyses have been dry reduced and normalized to 100 per cent for direct comparison.

$35.86^{\prime} \mathrm{E}$. Hole $430 \mathrm{~A}$ is the only hole to reach the volcanic sequence. Five lava flows were penetrated in the 28 meters of basement drilled. The top four flows are aphyric to very sparsely olivine and plagioclase phyric hawaiites. The fifth (bottom) flow is a plagio- 
clase and olivine phyric tholeiitic basalt of which only two pieces were recovered.

\section{Chemistry}

Chemically, the volcanic rocks recovered at Site 430 are similar to Hawaiian-type hawaiites and tholeiitic basalts (Macdonald, 1968). Table 2 presents the postcruise major-element analyses, both as received and dryreduced, along with CIPW norms assuming $\mathrm{Fe}^{+3} / \mathrm{Fe}^{+3}$ $+\mathrm{Fe}^{+2}=0.15$. Table 3 presents the post-cruise traceelement analyses. Figure 2 presents a diagram of total alkalis versus silica for all Leg 55 volcanic rocks. Figure
3 presents $\mathrm{MgO}$ variation diagrams for the Site 430 analyses, including both the shipboard and post-cruise data. Figure 4 presents the stratigraphic variation for each of the analyzed elements.

It is clear from the plot of total alkalis versus silica and the $\mathrm{MgO}$ variation diagrams that the hawaiites and the tholeiitic basalt are distinctly different rocks and cannot be related to each other, at least by low-pressure processes. The hawaiite flows, on the other hand, are very similar to each other. For most elements, the variation within Flow 1 is as large as or larger than variation between the flows. The hawaiites all have very similar

TABLE 2

Chemical Analyses and Norms of Volcanic Rocks from Hole 430A, $\overline{0}$ jin Seamount

\begin{tabular}{|c|c|c|c|c|c|c|c|}
\hline $\begin{array}{l}\text { Core-Sec., } \\
\text { Interval (cm) } \\
\text { Flow Unit }\end{array}$ & $\begin{array}{c}4-2,110-118 \\
1\end{array}$ & $\begin{array}{c}5-1,21-27 \\
1\end{array}$ & $\begin{array}{c}5-2,102-115 \\
1\end{array}$ & $6-1,17-25$ & $\begin{array}{c}6-3,52-63 \\
3\end{array}$ & $\begin{array}{c}6-4,7-15 \\
4\end{array}$ & $\begin{array}{c}6-4,140-150 \\
5\end{array}$ \\
\hline \multicolumn{8}{|c|}{ As Received } \\
\hline $\mathrm{SiO}_{2}$ & 47.06 & 47.60 & 48.11 & 48.33 & 47.80 & 48.03 & 47.66 \\
\hline $\mathrm{Al}_{2} \mathrm{O}_{3}$ & 16.72 & 15.88 & 15.53 & 15.80 & 16.18 & 15.42 & 15.29 \\
\hline $\mathrm{Fe}_{2} \mathrm{O}_{3}$ & 10.76 & 10.08 & 5.14 & 7.61 & 8.02 & 6.71 & 4.54 \\
\hline $\mathrm{FeO}$ & 2.21 & 2.84 & 6.62 & 3.98 & 4.03 & 4.85 & 7.91 \\
\hline $\mathrm{MgO}$ & 2.92 & 3.24 & 4.58 & 3.82 & 3.87 & 4.45 & 5.63 \\
\hline $\mathrm{CaO}$ & 5.80 & 6.61 & 6.84 & 7.14 & 6.58 & 6.69 & 10.98 \\
\hline $\mathrm{Na}_{2} \mathrm{O}$ & 4.26 & 4.29 & 4.08 & 4.34 & 4.30 & 4.26 & 3.00 \\
\hline $\mathrm{K}_{2} \mathrm{O}$ & 1.95 & 1.68 & 1.53 & 1.60 & 1.68 & 1.60 & 0.36 \\
\hline $\mathrm{H}_{2} \mathrm{O}^{+}$ & 1.23 & 1.02 & 1.53 & 0.94 & 1.17 & 1.53 & 0.39 \\
\hline $\mathrm{H}_{2} \mathrm{O}^{-}$ & 2.54 & 2.17 & 1.65 & 2.16 & 2.20 & 2.06 & 1.01 \\
\hline $\mathrm{TiO}_{2}$ & 3.16 & 3.06 & 2.92 & 2.92 & 2.88 & 2.73 & 2.76 \\
\hline $\mathrm{P}_{2} \mathrm{O}_{5}$ & 1.26 & 1.18 & 1.13 & 1.22 & 1.24 & 1.26 & 0.30 \\
\hline $\mathrm{MnO}$ & 0.07 & 0.07 & 0.13 & 0.09 & 0.11 & 0.13 & 0.18 \\
\hline $\mathrm{CO}_{2}$ & 0.11 & 0.10 & 0.03 & 0.03 & 0.05 & 0.04 & 0.04 \\
\hline Total (\%) & 100.05 & 99.82 & 99.82 & 99.98 & 100.11 & 99.76 & 100.05 \\
\hline \multicolumn{8}{|c|}{ Dry Reduced Normalized } \\
\hline $\mathrm{SiO}_{2}$ & 49.49 & 49.83 & 50.06 & 50.30 & 49.85 & 50.31 & 48.56 \\
\hline $\mathrm{Al}_{2} \mathrm{O}_{3}$ & 17.58 & 16.62 & 16.16 & 16.44 & 16.87 & 16.15 & 15.58 \\
\hline $\mathrm{FeO}$ & 12.51 & 12.47 & 11.70 & 11.27 & 11.73 & 11.41 & 12.22 \\
\hline $\mathrm{MgO}$ & 3.07 & 3.39 & 4.77 & 3.98 & 4.04 & 4.66 & 5.74 \\
\hline $\mathrm{CaO}$ & 6.10 & 6.92 & 7.12 & 7.43 & 6.86 & 7.01 & 11.19 \\
\hline $\mathrm{Na}_{2} \mathrm{O}$ & 4.48 & 4.49 & 4.25 & 4.52 & 4.48 & 4.46 & 3.06 \\
\hline $\mathrm{K}_{2} \mathrm{O}$ & 2.05 & 1.76 & 1.59 & 1.67 & 1.75 & 1.68 & 0.37 \\
\hline $\mathrm{TiO}_{2}$ & 3.32 & 3.20 & 3.04 & 3.04 & 3.00 & 2.86 & 2.81 \\
\hline $\mathrm{P}_{2} \mathrm{O}_{5}$ & 1.33 & 1.24 & 1.18 & 1.27 & 1.29 & 1.32 & 0.31 \\
\hline $\mathrm{MnO}$ & 0.07 & 0.07 & 0.14 & 0.09 & 0.11 & 0.14 & 0.18 \\
\hline \multicolumn{8}{|c|}{ Norms $\left(\mathrm{Fe}^{+3} /\left[\mathrm{Fe}^{+3}+\mathrm{Fe}^{+2}\right]\right)=0.15$} \\
\hline $\mathrm{C}$ & 0.08 & - & - & - & - & - & - \\
\hline OR & 12.09 & 10.38 & 9.38 & 9.85 & 10.32 & 9.91 & 2.18 \\
\hline $\mathrm{AB}$ & 37.83 & 37.92 & 35.89 & 38.17 & 37.84 & 37.67 & 25.83 \\
\hline AN & 21.53 & 19.96 & 20.28 & 19.60 & 20.72 & 19.05 & 27.62 \\
\hline DI & - & 5.22 & 6.02 & 7.40 & 4.03 & 5.84 & 21.24 \\
\hline DIWO & - & 2.60 & 3.04 & 3.72 & 2.02 & 2.94 & 10.75 \\
\hline DIEN & - & 1.05 & 1.49 & 1.73 & 0.92 & 1.44 & 5.48 \\
\hline DIFS & - & 1.57 & 1.49 & 1.95 & 1.09 & 1.46 & 5.01 \\
\hline $\mathrm{HY}$ & 4.49 & 3.61 & 7.01 & 2.79 & 3.18 & 4.74 & 6.66 \\
\hline HYEN & 1.71 & 1.45 & 3.50 & 1.31 & 1.45 & 2.35 & 3.48 \\
\hline HYFS & 2.78 & 2.16 & 3.51 & 1.48 & 1.72 & 2.39 & 3.18 \\
\hline FO & 4.15 & 4.15 & 4.81 & 4.80 & 5.38 & 5.46 & 3.72 \\
\hline FA & 7.44 & 6.82 & 5.31 & 5.97 & 7.03 & 6.11 & 3.75 \\
\hline MT & 3.02 & 3.01 & 2.82 & 2.72 & 2.84 & 2.75 & 2.95 \\
\hline IL & 6.29 & 6.06 & 5.76 & 5.76 & 5.69 & 5.42 & 5.32 \\
\hline $\mathrm{AP}$ & 3.14 & 2.93 & 2.79 & 3.00 & 3.05 & 3.12 & 0.73 \\
\hline Total (\%) & 100.07 & 100.06 & 100.06 & 100.07 & 100.07 & 100.07 & 100.02 \\
\hline
\end{tabular}

Note: $\mathrm{Cl}$ analysis on Sample 4-2, 110-118 cm gave $<0.05$ percent. 
TABLE 3

Trace-Element Analyses of Lava Flows from Ōjin Seamount, DSDP Hole 430A. Concentrations in ppm

\begin{tabular}{lccrrrrrr}
\hline & & \multicolumn{7}{c}{ Concentrations (ppm) } \\
$\begin{array}{l}\text { Core-Section, } \\
\text { Interval (cm) }\end{array}$ & $\begin{array}{r}\text { Flow } \\
\text { Unit }\end{array}$ & $\mathrm{Ba}$ & $\mathrm{Cr}$ & $\mathrm{Ni}$ & $\mathrm{Sr}$ & $\mathrm{Zn}$ & $\mathrm{Zr}$ & $\mathrm{Y}$ \\
\hline $4-2,110-118$ & 1 & 410 & $<100$ & $<2$ & 660 & 148 & 420 & 57 \\
$5-1,21-27$ & 1 & 415 & $<100$ & 17 & 670 & 187 & 400 & 57 \\
$5-2,102-115$ & 1 & 395 & $<100$ & 18 & 510 & 141 & 370 & 40 \\
$6-1,17-25$ & 2 & 410 & $<100$ & 12 & 690 & 650 & 430 & 55 \\
$6-3,52-63$ & 3 & 420 & $<100$ & 13 & 660 & 178 & 415 & 52 \\
$6-4,7-15$ & 4 & 410 & $<100$ & 12 & 650 & 186 & 435 & 58 \\
$6-4,140-150$ & 5 & 138 & 108 & 59 & 355 & 101 & 170 & 16
\end{tabular}

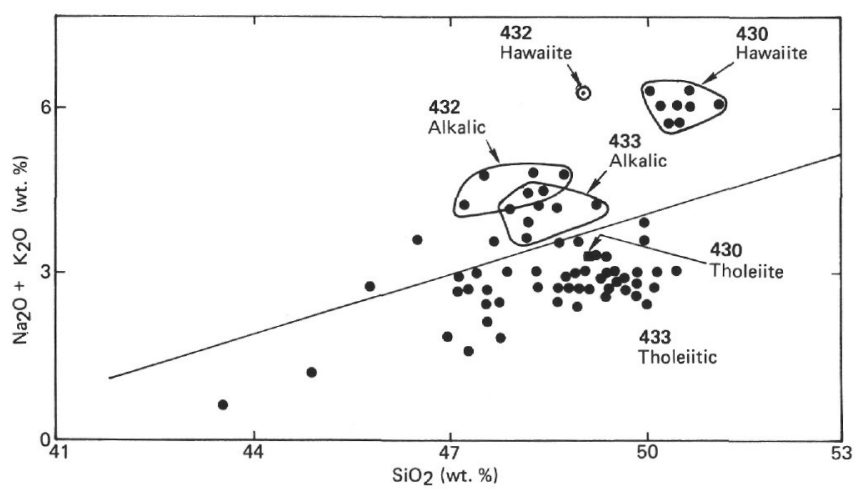

Figure 2. Total alkalis versus silica for all Leg $55 \mathrm{vol}$ canic rocks (shipboard analyses only).

magnetic inclinations (see 430 Site Chapter), and are probably from the same eruptive event.

\section{Petrography}

Table 4 presents the modal mineralogy, the modal percentages of alteration product, the $d$-spacings of the clays, the olivine replacement, the nature and amount of vesicle filling (usually clay or zeolite), and the presence or absence of carbonate in each thin section examined. Because the modes for these samples were done using standard $30-\mu \mathrm{m}$-thick thin sections, the percentage of clays is probably slightly high. Figure 5 presents the modal phenocryst mineralogy versus depth in the hole.

The phenocrysts in the hawaiites, when present, are olivine and plagioclase. The groundmass minerals are olivine, clinopyroxene, plagioclase, titanomagnetite, apatite, and clay after glass. Most of the olivine is altered to saponitic clay or iddingsite, but some grains are still fresh. The textures in the hawaiites are subtrachytic, and vary from intergranular near flow margins to subophitic near flow centers. Figure 6 illustrates typical textures. Avdeiko et al. (this volume) discuss the textural variations within flows in more detail.

The phenocryst minerals in the tholeiitic basalt are olivine, augitic clinopyroxene, and plagioclase. The groundmass phases are olivine, clinopyroxene, plagioclase, titanomagnetite, ilmenite, and clays after glass. The texture is intergranular. Figure 6 illustrates the texture.

\section{Alteration}

The plagioclase, clinopyroxene, and iron-titanium oxides in both the hawaiites and the tholeiite are uniformly fresh. The interstitial glass and much of the olivine (both phenocryst and groundmass) are altered to saponitic clay. Some olivine is fresh and some altered to iddingsite.

\section{Stratigraphy}

Macdonald and Katsura (1964) and Macdonald (1968) have described a sequence of eruptive phases which commonly recur in Hawaiian volcanoes. Not each of these phases occurs at all volcanoes, but the sequence seems common enough to be considered a reference for comparison with the drilled sequences. This sequence of eruptive phases is typical of the Hawaiian chain and very rare in other oceanic islands. Macdonald (1968) identified four stages in the development of a Hawaiian volcano. They are, from earliest to latest:

1. Shield-building stage: tholeiitic basalts

2. Caldera-filling stage: tholeiitic or alkalic basalts or both. Stages 1 and 2 together make up 99 per cent of the volcano.

3. Post-caldera stage: alkalic basalts and associated differentiated lavas, about 1 per cent of the volcano.

4. Post-erosional stage: alkalic basalts, nepheline basalts, and nepheline melilite basalts, less than 1 per cent of the volcano.

In a hole drilled into a complete sequence like this it would be possible to distinguish three stages: tholeiitic basalts at the bottom, alkalic basalts and hawaiities above them, and on top a thin veneer of strongly alkalic post-erosional flows.

The drilled sequence of volcanic rocks at Site 430 is meager (about $28 \mathrm{~m}$ ), and only one tholeiitic flow was encountered, so it is difficult to determine whether the sequence is the same as on the Hawaiian volcanoes. The Hole 430A sequence with four hawaiite flows overlying a tholeiitic flow is, however, consistent with the Hawaiian sequences. On the basis of pyroxene and feldspar chemistry (Clague et al., this volume), the hawaiites appear to belong to the caldera-filling or post-caldera stage rather than the post-erosional stage.

\section{SITE 432}

Site 432 was drilled into perched terrace deposits on the north side of Nintoku seamount at $41^{\circ} 20.03^{\prime} \mathrm{N}$, $170^{\circ} 22.74^{\prime} \mathrm{E}$. Hole $432 \mathrm{~A}$ is the only hole to penetrate the volcanic sequence. Three flow units of olivine \pm plagioclase \pm clinopyroxene phyric alkali basalt occur in the $\mathbf{3 2}$ meters of basement drilled. In addition, there are cobbles of volcanic rock in a conglomerate which overlies the basalt. The one analyzed cobble is an aphanitic hawaiite.

\section{Chemistry}

Chemically the Site 432 volcanics are similar to Hawaiian-type alkalic basalts and hawaiites (Macdon- 

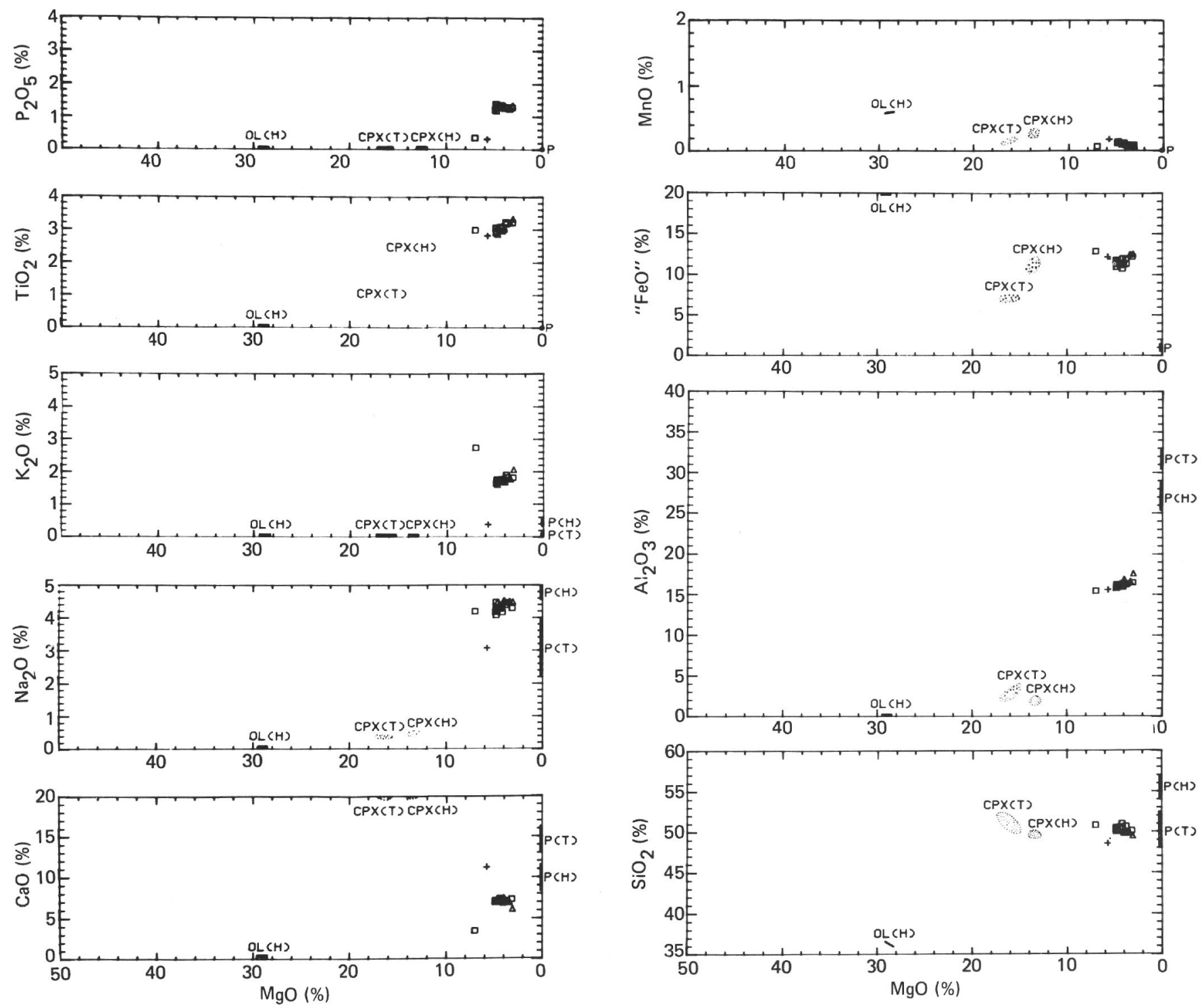

Figure 3. $\mathrm{MgO}$ variation diagrams for Site 430 volcanic rocks, including phenocryst compositions (Clague et al., this volume). Point at $\mathrm{MgO}=7.0 \%$ is sand. 

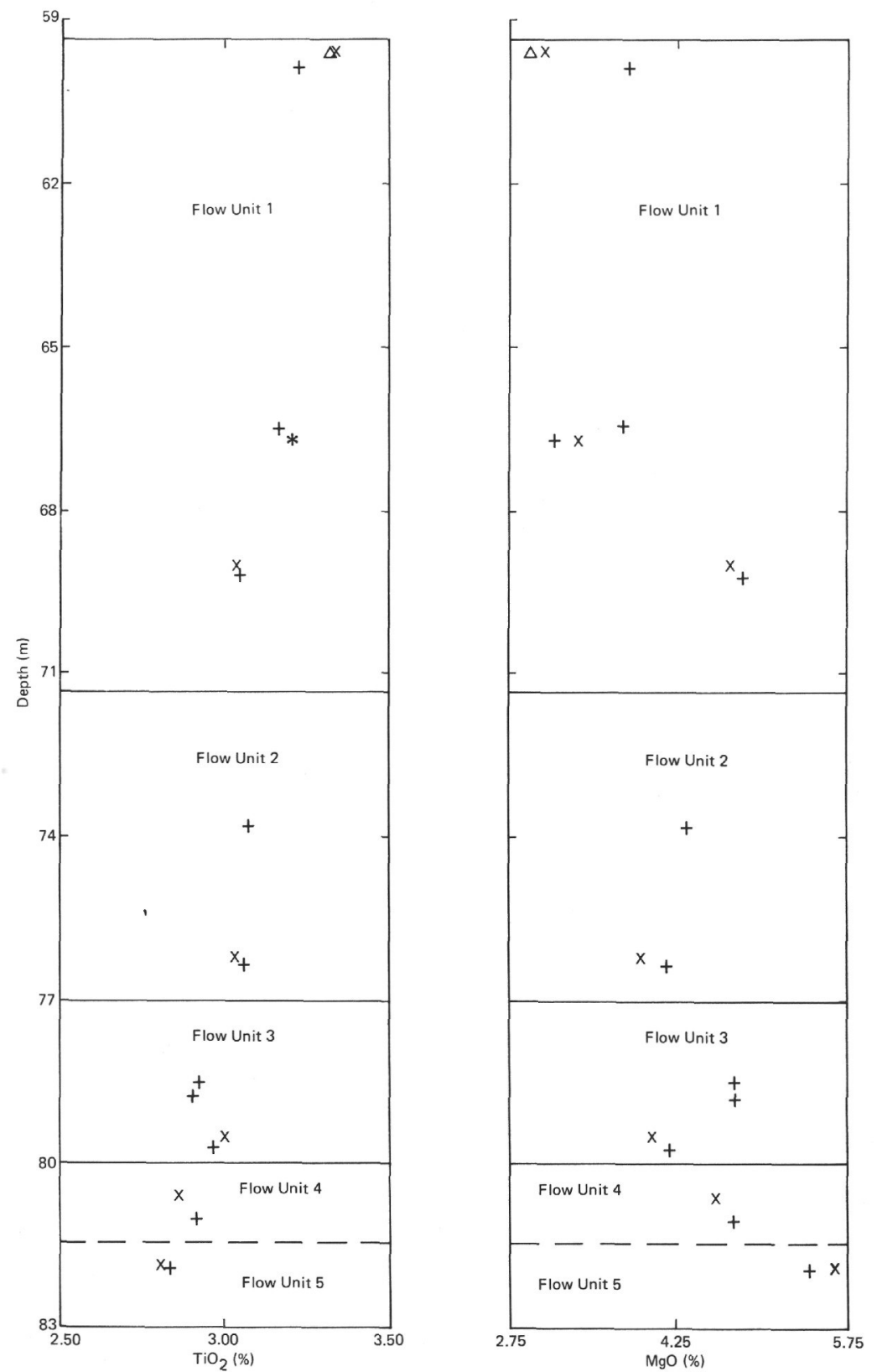

Figure 4. Downhole variation in $\mathrm{MgO}$ and $\mathrm{TiO}_{2}$ for Hole $430 \mathrm{~A}$ volcanic rocks. $+=$ shipboard analysis and $\times=$ shorebased anal yses.
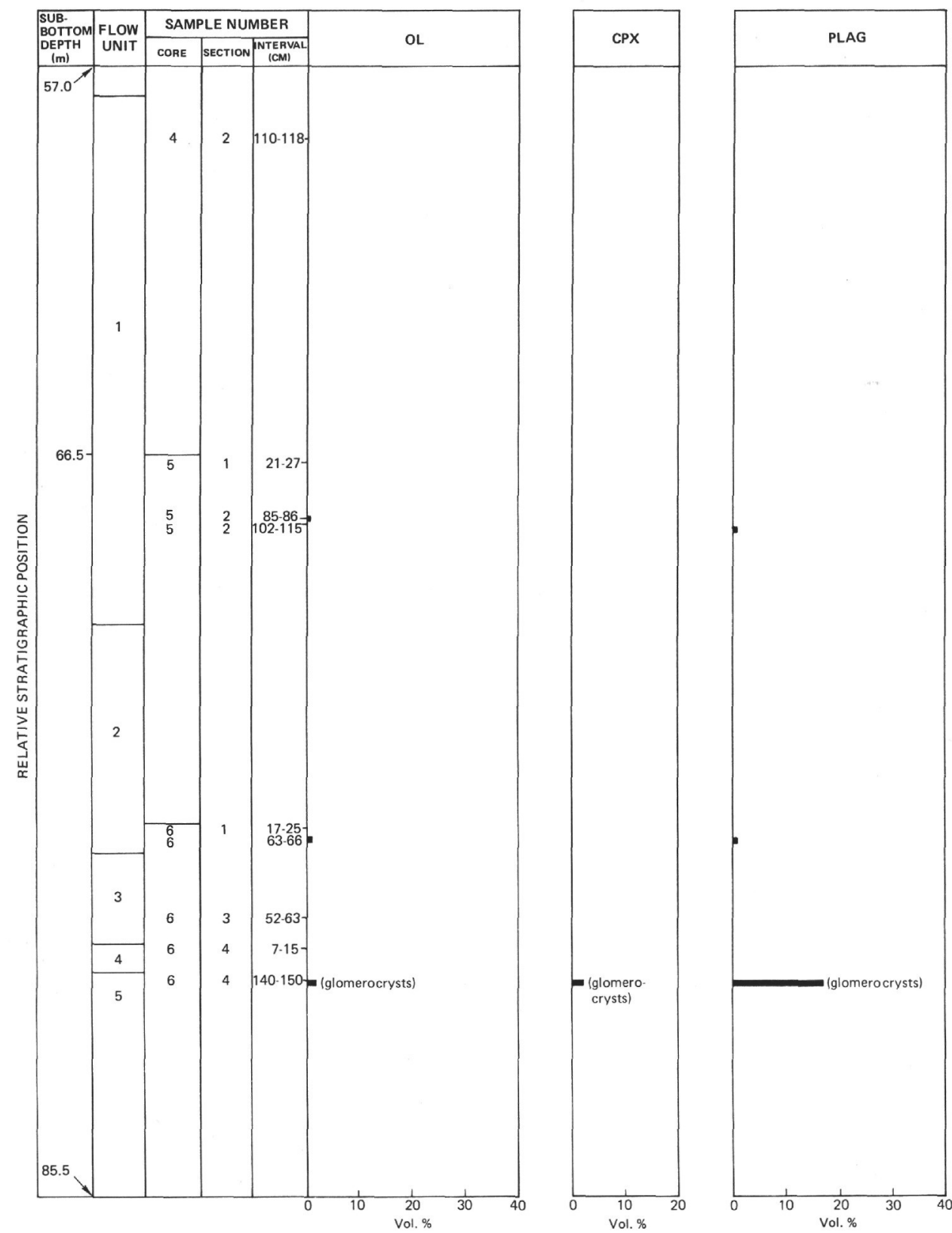

Figure 5. Downhole variation in phenocryst mineralogy for Hole $430 \mathrm{~A}$ volcanic rocks. 

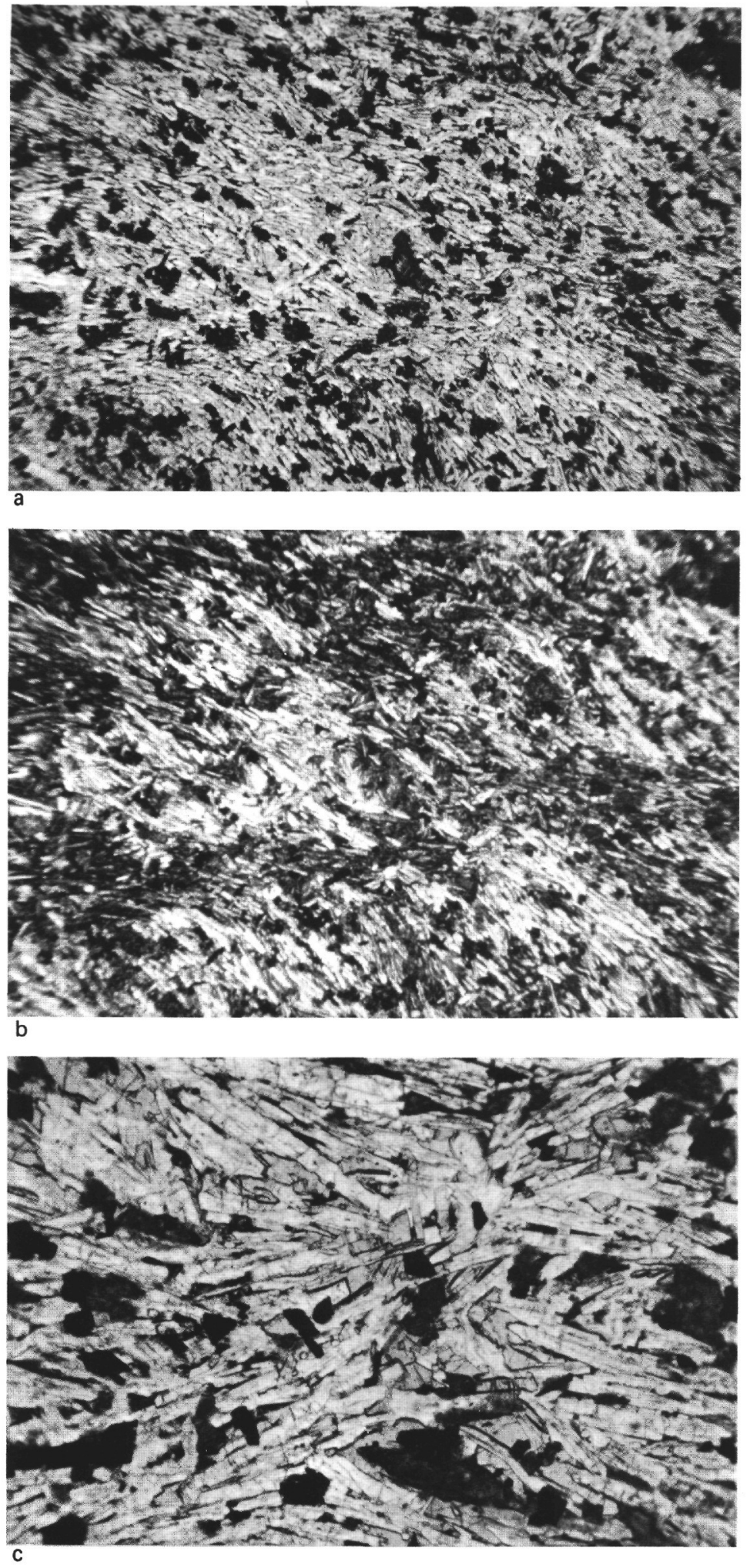

Figure 6. Photomicrographs of Site 430 volcanic rock. A) Trachytic texture in hawaiite, Sample 430A-5-2, 120-123 cm. Plane light. Length of field is $4.9 \mathrm{~mm}$. B) Same as A, but crossed nicols. Notice areas of subparallel plagioclase laths which are all in the extinction positions. C) Intergranular texture of hawaiite, Sample 430A-5-2, 120-123 cm. Notice clinopyroxene between plagioclase laths with trachytic texture. Plane light; length of field is $1.3 \mathrm{~mm}$. 
TABLE 4

Petrographic Summary for Hole 430A Volcanic Rocks

\begin{tabular}{|c|c|c|c|c|c|c|c|c|c|c|c|c|c|}
\hline \multirow[b]{2}{*}{$\begin{array}{l}\text { Core-Section, } \\
\text { Interval (cm) }\end{array}$} & \multirow[b]{2}{*}{$\begin{array}{l}\text { Flow } \\
\text { Unit }\end{array}$} & \multirow[b]{2}{*}{ Rock Type } & \multicolumn{3}{|c|}{ Phenocrysts \& Microphenocrysts } & \multirow[b]{2}{*}{ Per cent } & \multicolumn{4}{|c|}{ Groundmass } & \multirow[b]{2}{*}{ Opaque Minerals } & \multirow[b]{2}{*}{ Alteration and Remarks $b$} & \multirow[b]{2}{*}{ Other Work } \\
\hline & & & Mineral & Per cent & $\begin{array}{l}\text { Average } \\
\text { Size } \\
(\mathrm{mm})\end{array}$ & & $\begin{array}{c}\text { Dominant } \\
\text { Texture }\end{array}$ & $\begin{array}{l}\text { Size Range } \\
(\mathrm{mm})\end{array}$ & Mineralsa & Per cent & & & \\
\hline $4-2,110-118$ & 1 & Hawaiite & & & & 100 & subtrachytic & $\begin{array}{l}0.01-0.95 \\
0.005-0.28 \\
0.01-0.40 \\
0.005-0.40 \\
0.01-0.50 \\
0.01-0.28\end{array}$ & $\begin{array}{l}\mathrm{pl} \\
\mathrm{cpx} \\
\text { ol } \\
\mathrm{mt} \\
\text { il } \\
\text { ap }\end{array}$ & $\begin{array}{r}57 \\
19 \\
13 \\
5 \\
4 \\
2\end{array}$ & $\begin{array}{l}\text { Exsolved equant timag. } \\
\text { and elongate ilmenite. } \\
\text { Pyrite common and } \\
\text { chalcopyrite present in } \\
\text { pools of clays. }\end{array}$ & $\begin{array}{l}22 \% \text { altered, ol completely } \\
\text { replaced by iddingsite and } \\
\text { smectite. Smectite has } \\
\text { basal } d=12.62 \AA \text { which splits } \\
\text { to a } 14.72 \AA \text { and a } 16.92 \AA \\
\text { peak after glycol. Mainly } \\
\text { smectite } \mathrm{A} \text { but trace of } \mathrm{B} \\
\text { also. Mt partly replaced by } \\
\text { hematite. }\end{array}$ & $\begin{array}{l}\mathrm{W}, \mathrm{X}, \mathrm{T}, \mathrm{M} \\
\mathrm{S}, \mathrm{K}\end{array}$ \\
\hline $5-1,21-27$ & 1 & Hawaiite & & & & $99^{+}$ & $\begin{array}{l}\text { subtrachy tic, } \\
\text { intersertal }\end{array}$ & $\begin{array}{l}0.01-1.55 \\
0.005-0.50 \\
0.01-0.50 \\
0.005-0.48 \\
0.01-0.65 \\
0.01-0.50\end{array}$ & $\begin{array}{l}\mathrm{pl} \\
\mathrm{cpx} \\
\text { ol } \\
\mathrm{mt} \\
\text { il } \\
\text { ap }\end{array}$ & $\begin{array}{r}62 \\
16 \\
7 \\
7 \\
4 \\
3\end{array}$ & $\begin{array}{l}\text { Exsolved equant timag. } \\
\text { and rare elongate } \\
\text { ilmenite. Most timag. } \\
\text { have undergone long- } \\
\text { term oxidation and are } \\
\text { flat gray to white in } \\
\text { reflecting light. }\end{array}$ & $\begin{array}{l}\sim 12 \% \text { altered, ol completely } \\
\text { replaced by smectite and } \\
\text { rare calcite. Smectite has } \\
\text { basal } d=12.44 \AA \text { which ex- } \\
\text { pands to } 17.31 \AA \text { after } \\
\text { glycol. Smectite A only. }\end{array}$ & $\underset{\mathrm{K}}{\mathrm{X}, \mathrm{T}, \mathrm{M}, \mathrm{S},}$ \\
\hline $5-2,85-86$ & I & Hawaiite & ol & $<1$ & 0.53 & 100 & $\begin{array}{l}\text { subtrachytic } \\
\text { intersertal }\end{array}$ & $\begin{array}{l}0.02-0.55 \\
0.005-0.50 \\
0.02-0.50 \\
0.02-0.50 \\
\text { up to } 0.50 \\
0.005-0.008\end{array}$ & $\begin{array}{l}\mathrm{pl} \\
\mathrm{cpx} \\
\text { ol } \\
\text { il } \\
\text { ap } \\
\mathrm{mt}\end{array}$ & $\begin{array}{r}63 \\
16 \\
11 \\
5 \\
3 \\
2\end{array}$ & & $\begin{array}{l}25 \% \text { altered, nearly all ol re- } \\
\text { placed by smectite. Smec- } \\
\text { tite has basal } d=14.24 \AA \\
\text { which expands to } 16.98 \AA \\
\text { after glycol. Mainly smec- } \\
\text { tite A but trace of B also. }\end{array}$ & \\
\hline $5-2,102-115$ & 1 & Hawaiite & $\mathrm{pl}$ & $<1$ & 1.35 & $99^{+}$ & $\begin{array}{l}\text { subtrachytic, } \\
\text { intersertal }\end{array}$ & $\begin{array}{ll}0.05 & -0.60 \\
0.04 & -0.50 \\
0.05 & -0.48 \\
0.02 & -0.40 \\
0.04 & -0.49 \\
0.05 & -0.07\end{array}$ & $\begin{array}{l}\mathrm{pl} \\
\mathrm{cpx} \\
\text { ol } \\
\mathrm{mt} \\
\text { il } \\
\text { ap }\end{array}$ & $\begin{array}{r}60 \\
20 \\
10 \\
6 \\
2 \\
1\end{array}$ & $\begin{array}{l}\text { Timag. and ilmenite. } \\
\text { Timag. has ilmenite } \\
\text { exsolution lamellae. }\end{array}$ & $\begin{array}{l}21 \% \text { altered, nearly all ol } \\
\text { replaced by iddingsite } \\
\text { and smectite. Smectite } \\
\text { has basal } d=14.24 \AA \text { which } \\
\text { expands to } 16.66 \AA \text { after } \\
\text { glycol. Mainly smectite } A \\
\text { but trace of B also. }\end{array}$ & $\begin{array}{l}\mathrm{X}, \mathrm{P}, \mathrm{T}, \mathrm{R} 2 \\
\mathrm{M}\end{array}$ \\
\hline $6-1,17-25$ & 2 & Hawaiite & & & & 100 & subtrachytic & $\begin{array}{ll}0.10 & -0.70 \\
0.05 & -0.30 \\
0.04 & -0.49 \\
0.05 & -0.30 \\
\text { up to } 0.10 \\
0.02-0.33\end{array}$ & $\begin{array}{l}\mathrm{pl} \\
\mathrm{cpx} \\
\text { ol } \\
\mathrm{mt} \\
\text { ap } \\
\text { il }\end{array}$ & $\begin{array}{r}61 \\
23 \\
10 \\
5 \\
<1 \\
1\end{array}$ & $\begin{array}{l}\text { Equant exsolved } \\
\text { timag. and elongate } \\
\text { ilmenite. }\end{array}$ & $\begin{array}{l}\sim 19 \% \text { altered, nearly all } \\
\text { ol replaced by iddingsite } \\
\text { and smectite and calcite. } \\
\text { Smectite has basal } d= \\
13.80 \AA \text { which expands to } \\
17.31 \AA \text { after glycol. } \\
\text { Mainly smectite } \mathrm{A} \text { but } \\
\text { trace of } \mathrm{B} \text { also. }\end{array}$ & $\begin{array}{l}\mathrm{X}, \mathrm{P}, \mathrm{T}, \mathrm{R} 2, \\
\mathrm{M}\end{array}$ \\
\hline $6-1,63-66$ & 2 & Hawaiite & $\begin{array}{l}\mathrm{pl} \\
\mathrm{ol}\end{array}$ & $\begin{array}{l}<1 \\
<1\end{array}$ & $\begin{array}{l}0.83 \\
0.55\end{array}$ & 100 & $\begin{array}{l}\text { subtrachytic, } \\
\text { intersertal }\end{array}$ & $\begin{array}{l}0.005-0.50 \\
0.006-0.50 \\
0.008-0.50 \\
0.001-0.20 \\
0.006-0.30 \\
0.005-0.41\end{array}$ & $\begin{array}{l}\mathrm{pl} \\
\mathrm{cpx} \\
\mathrm{ol} \\
\mathrm{mt} \\
\mathrm{ap} \\
\text { il }\end{array}$ & $\begin{array}{r}54 \\
18 \\
12 \\
8 \\
5 \\
3\end{array}$ & & $\begin{array}{l}25 \% \text { altered, ol completely } \\
\text { replaced by iddingsite and } \\
\text { smectite. Smectite has } \\
\text { basal } d=14.02 . \AA \text { which ex- } \\
\text { pands to } 17.31 \AA \text { after } \\
\text { glycol. Mainly smectite A } \\
\text { but trace of B also. Rims } \\
\text { of mt altered to hematite. }\end{array}$ & \\
\hline $6-3,52-63$ & 3 & Hawaiite & & & & $99^{+}$ & subtrachytic & $\begin{array}{l}0.007-0.75 \\
0.008-0.10 \\
0.01-0.09 \\
0.03-0.50 \\
0.18-0.40 \\
0.007-0.01\end{array}$ & $\begin{array}{l}\mathrm{pl} \\
\mathrm{cpx} \\
\mathrm{mt} \\
\text { ol } \\
\text { il } \\
\text { ap }\end{array}$ & $\begin{array}{r}64 \\
22 \\
5 \\
4 \\
3 \\
1\end{array}$ & $\begin{array}{l}\text { Equant exsolved } \\
\text { timag. and elongate } \\
\text { ilmenite. }\end{array}$ & $\begin{array}{l}\sim 15 \% \text { altered, ol com- } \\
\text { pletely replaced by smec- } \\
\text { tite. Smectite has basal } \\
d=14.02 \AA \text { which expands } \\
\text { to } 16.98 \AA \text { after glycol. } \\
\text { Mainly smeetite A but } \\
\text { trace of B also. }\end{array}$ & $\begin{array}{l}\mathrm{X}, \mathrm{P}, \mathrm{T}, \mathrm{R} 2, \\
\mathrm{M}, \mathrm{S}, \mathrm{K}\end{array}$ \\
\hline $6-4,7-15$ & 4 & Hawaiite & & & & 100 & subtrachytic & $\begin{array}{l}0.01-0.90 \\
0.006-0.20 \\
0.01-0.64 \\
0.004-0.20 \\
0.005-0.30 \\
\text { up to } 0.08\end{array}$ & $\begin{array}{l}\mathrm{pl} \\
\mathrm{cpx} \\
\text { ol } \\
\mathrm{mt} \\
\text { il } \\
\text { ap }\end{array}$ & $\begin{array}{r}63 \\
17 \\
12 \\
4 \\
4 \\
<1\end{array}$ & Timag and ilmenite. & $\begin{array}{l}28 \% \text { altered, } 85 \% \text { of ol re- } \\
\text { placed by iddingsite and } \\
\text { smectite. Smectite has } \\
\text { basal } d=13.80 \AA \text { which ex- } \\
\text { pands to } 17.31 \AA \text { after } \\
\text { gly col. Both smeetite } \mathrm{A} \\
\text { and B are abundant. Mt } \\
\text { partly replaced. }\end{array}$ & $\begin{array}{l}X, T, M, S \\
K\end{array}$ \\
\hline $6-4,140-150$ & 5 & $\begin{array}{l}\text { Plagioclase } \\
\text { Tholeiite }\end{array}$ & $\begin{array}{l}\mathrm{pl} \\
\mathrm{cpx} \\
\mathrm{ol}\end{array}$ & $\begin{array}{r}17 \\
2 \\
1\end{array}$ & $\begin{array}{l}1.47 \\
1.33 \\
1.22\end{array}$ & 87 & $\begin{array}{l}\text { Glomerophyric } \\
\text { intergranular }\end{array}$ & $\begin{array}{l}0.25-0.50 \\
0.006-0.40 \\
0.005-0.08 \\
0.008-0.10 \\
0.01-0.50\end{array}$ & $\begin{array}{l}\mathrm{pl} \\
\mathrm{cpx} \\
\mathrm{mt} \\
\text { il } \\
\text { ol }\end{array}$ & $\begin{array}{r}42 \\
32 \\
2 \\
2 \\
2\end{array}$ & $\begin{array}{l}\text { Timag. and ilmenite. } \\
\text { Pyrite is rare. }\end{array}$ & $\begin{array}{l}5 \% \text { al tered, ol completely } \\
\text { replaced by iddingsite and } \\
\text { smectite. Smectite has } \\
\text { basal } d=15.49 \AA \text { that ex- } \\
\text { pands to } 17.31 \AA \text { after } \\
\text { glycol. Only smectite } A \\
\text { is present. Pl phenocrysts } \\
\text { are strongly zoned and con- } \\
\text { tain glass inclusions. }\end{array}$ & $\begin{array}{l}\mathrm{X}, \mathrm{P}, \mathrm{T}, \mathrm{R} 2, \\
\mathrm{M}, \mathrm{S}, \mathrm{K}\end{array}$ \\
\hline
\end{tabular}

Note: $\mathrm{pl}=$ plagioclase; $\mathrm{ol}=$ olivine; $\mathrm{cpx}=$ clinopyroxene; il = ilmenite; $\mathrm{mt}=$ magnetite; ap = apatite $\mathrm{kf}=$ potash feldspar.

a By modal analysis of ordinary thin sections. Magnetite distinguished from ilmenite by shape. All percentages corrected for low-temperature alteration.

Other Work: $\mathrm{W}=$ wet chemical analysis.

$\mathrm{X}=\mathrm{X}$-ray fluorescence for majors

$P=$ microprobe for majors (Bence et al.)

R1 = INAA for rare earths and trace elements (Clague and Frey)

$R 2=E S$ for rare earths and trace elements (Bence et al.)

$\mathrm{S}=\mathrm{Sr}$ isotopic analy sis (Lanphere et al.

$\mathrm{K}=\mathrm{K}-\mathrm{Ar}$ ages (Dalrymple et al. $)$

$\mathrm{M}=$ microprobe mineral analyses (Clague et al.) 
ald, 1968). Table 5 presents the post-cruise major-element data both as received and dry-reduced, along with CIPW norms assuming $\mathrm{Fe}^{+3} / \mathrm{Fe}^{+3}+\mathrm{Fe}^{+2}=0.15$. Table 6 presents the post-cruise trace-element data. Figure 2 plots total alkalis versus silica. Figure 7 presents $\mathrm{MgO}$ variation diagrams and Figure 8 shows composition versus depth, using both the shore-based and shipboard analyses.

TABLE 5

Chemical Analyses and Norms of Volcanic Rocks from Hole 432A, Nintoku Seamount

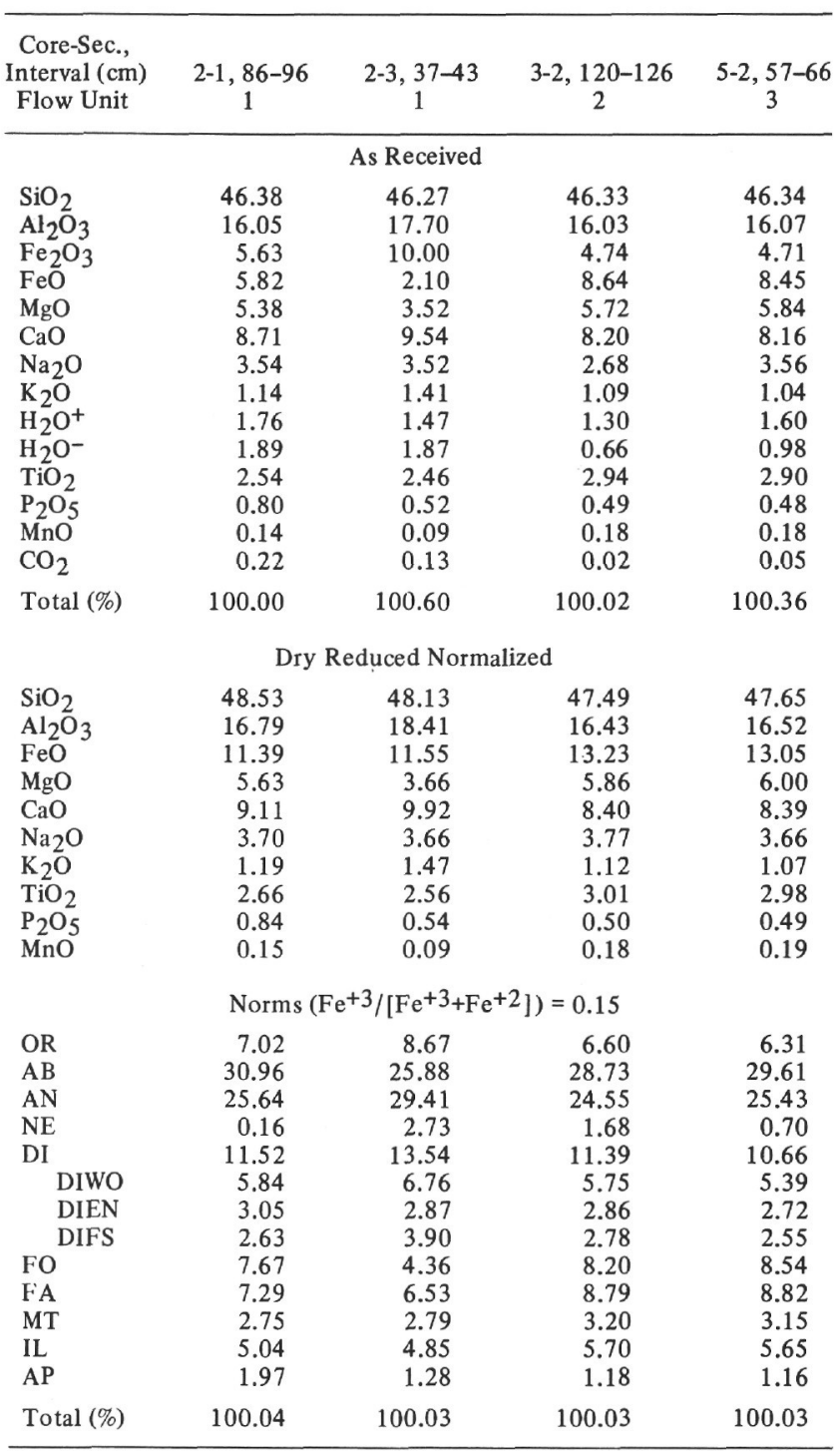

TABLE 6

Trace-Element Analyses of Lava Flows from Nintoku Seamount, DSDP Hole 432A

\begin{tabular}{lccrrrrrr}
\hline $\begin{array}{l}\text { Core-Section, } \\
\text { Interval }(\mathrm{cm})\end{array}$ & $\begin{array}{c}\text { Flow } \\
\text { Unit }\end{array}$ & $\mathrm{Ba}$ & $\mathrm{Cr}$ & $\mathrm{Ni}$ & $\mathrm{Sr}$ & $\mathrm{Zn}$ & $\mathrm{Zr}$ & $\mathrm{Y}$ \\
\hline $2-1,86-96$ & 1 & 365 & $<100$ & 45 & 640 & 123 & 265 & 36 \\
$2-3,37-43$ & 2 & 375 & 111 & 79 & 640 & 103 & 169 & 12 \\
$3-2,120-126$ & 3 & 365 & 113 & 49 & 420 & 99 & 184 & $<9$ \\
$5-2,57-66$ & 3 & 400 & 110 & 47 & 495 & 126 & 191 & 33 \\
\hline
\end{tabular}

The three alkali basalt flows at Site $\mathbf{4 3 2}$ are generally similar to each other. Flows 1 and 2 have similar magnetic inclinations $\left(-66^{\circ}\right.$ to $\left.-67^{\circ}\right)$; Flow Unit 3 has a much lower inclination $\left(-29^{\circ}\right)$. Although no quantitative calculations have been made, Flows 1 and 2 may be related. Because of the large difference in magnetic inclination, Flow Unit 3 is probably not directly related to the others. Flow Unit 1 appears to be somewhat more differentiated than Flow Unit 2. If they are related, it is not by olivine fractionation alone. The composition of the hawaiite cobble is considerably different from the alkali basalts. Because of the small number of analyzed flows it is not possible to usefully examine the chemical relationships between the two rock types.

\section{Petrography}

Table 7 presents the modal mineralogy, the modal percentages of alteration product, the $d$-spacings of the clay minerals, the olivine replacement, the nature and amount of vesicle filling (usually clay or zeolite), and the presence or absence of carbonate in each Site 432 thin section examined. Figure 9 presents the modal phenocryst mineralogy versus depth for the samples examined.

All three alkali basalt flows contain plagioclase, clinopyroxene, and olivine phenocrysts. Flow Units 1 and 2 are richer in plagioclase: Flow 3 is richer in clinopyroxene. The groundmass minerals are olivine, clinopyroxene, plagioclase, titanomagnetite, apatite, clay after glass, and a trace of biotite. The hawaiite cobble is essentially aphyric. Its groundmass minerals are olivine, clinopyroxene, plagioclase, titanomagnetite, apatite, and clay after glass.

The textures in the alkali basalts range from intersertal through intergranular to sub-ophitic or ophitic. The hawaiite is subtrachytic and intergranular. Figure 10 presents photomicrographs of typical textures in these rocks.

\begin{abstract}
Alteration
The plagioclase and clinopyroxene in both the alkali basalts and the hawiite are uniformly fresh. The interstitial groundmass glass and much of the olivine are altered to saponitic clay. Some of the olivine is fresh and some altered to iddingsite. Much of the titanomagnetite contains exsolved ilmenite, and some is altered to titanomaghemite.
\end{abstract}

\section{Stratigraphy}

As at Site 430, because of technical problems, the drilling at Site 432 did not continue deep enough to determine whether the sequence of flows is the same as the typical Hawaiian sequence. The presence of alkali basalts at the top, however, is consistent with this sequence. On the basis of their pyroxene and feldspar chemistry, the alkali basalt flows appear to belong to the caldera-filling stage or post-cladera stage, and not to the post-erosional stage (Clague et al., this volume). 

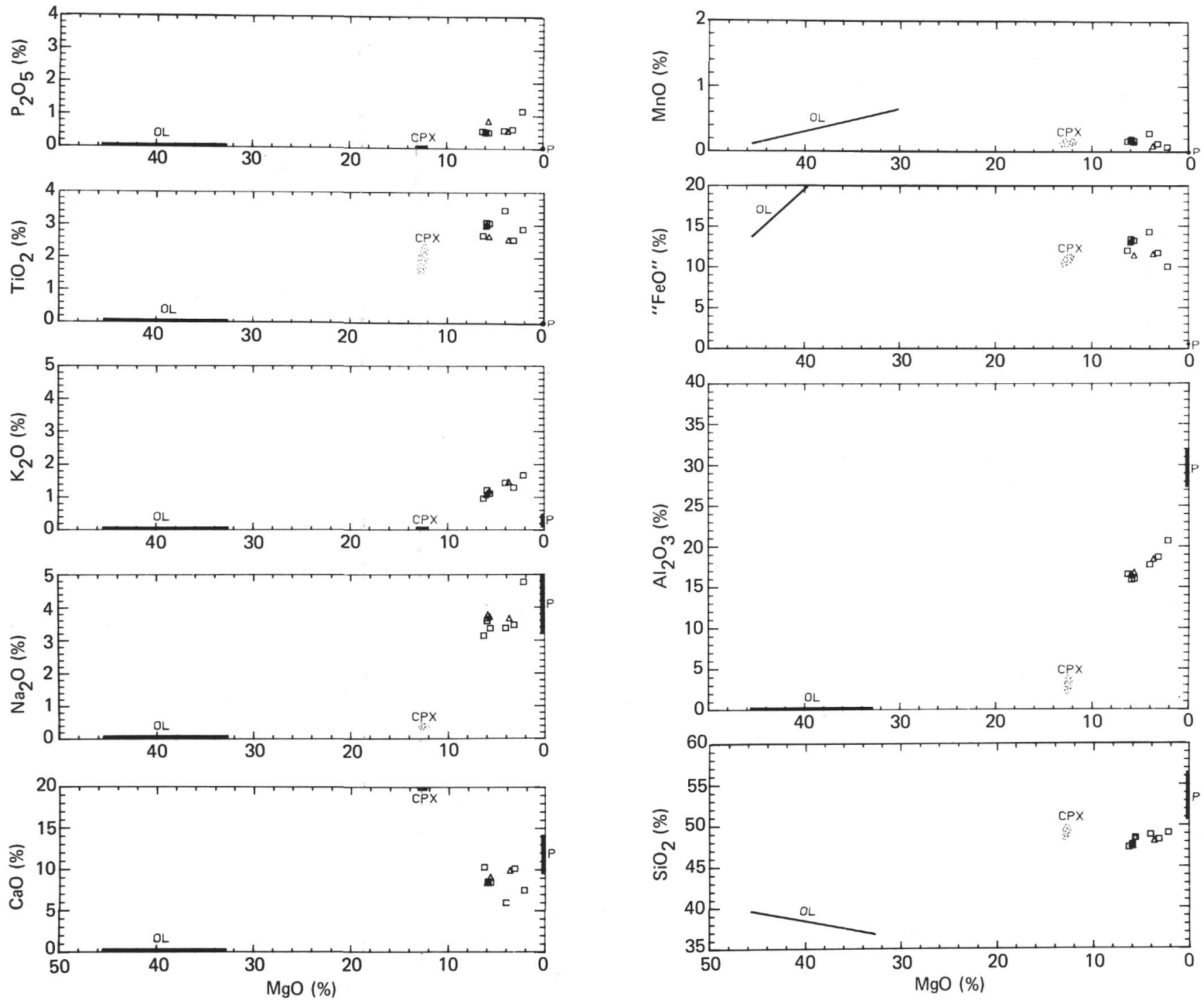

Figure 7. $\mathrm{MgO}$ variation diagrams for Site 432 volcanic rocks, including phenocryst compositions (Clague et al., this volume). 

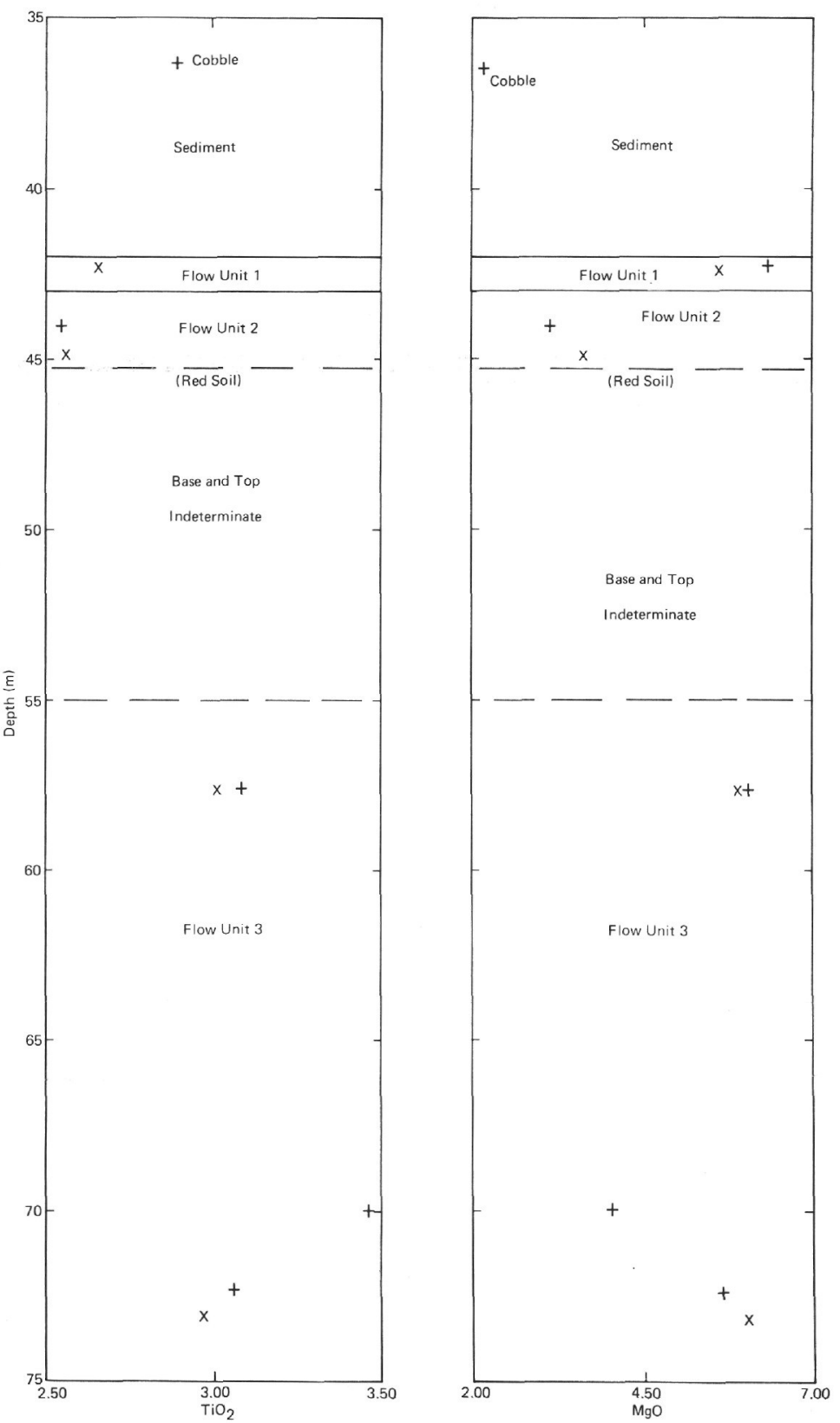

Figure 8. Downhole variation in $\mathrm{MgO}$ and $\mathrm{TiO}_{2}$ for Hole $432 \mathrm{~A}$ volcanic rocks. $+=$ shipboard analysis and $\times=$ shorebased analysis.
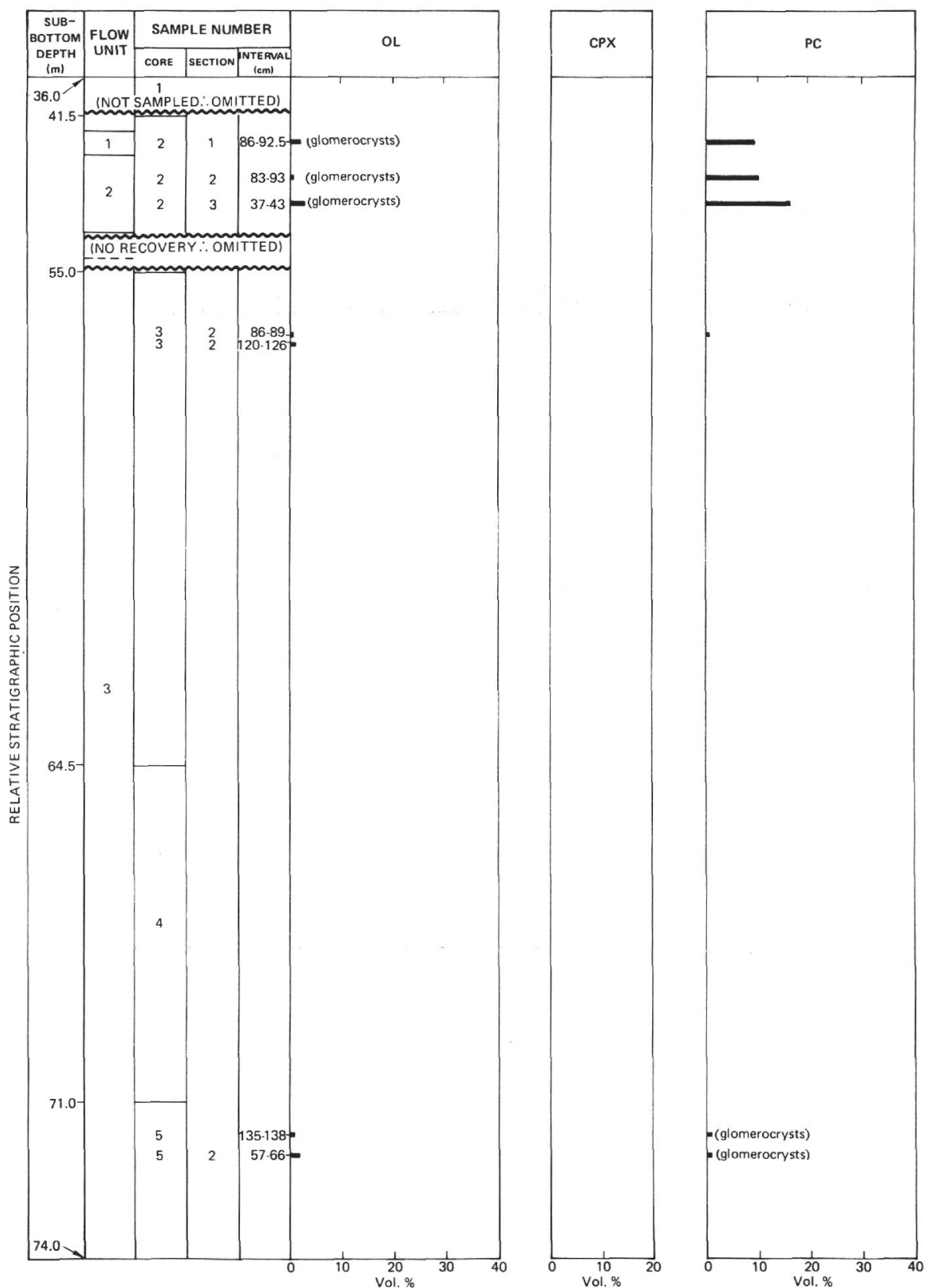

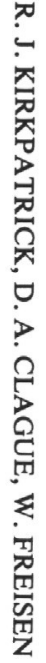

Figure 9. Downhole variation in phenocryst mineralogy for Hole $432 \mathrm{~A}$ volcanic rocks. 

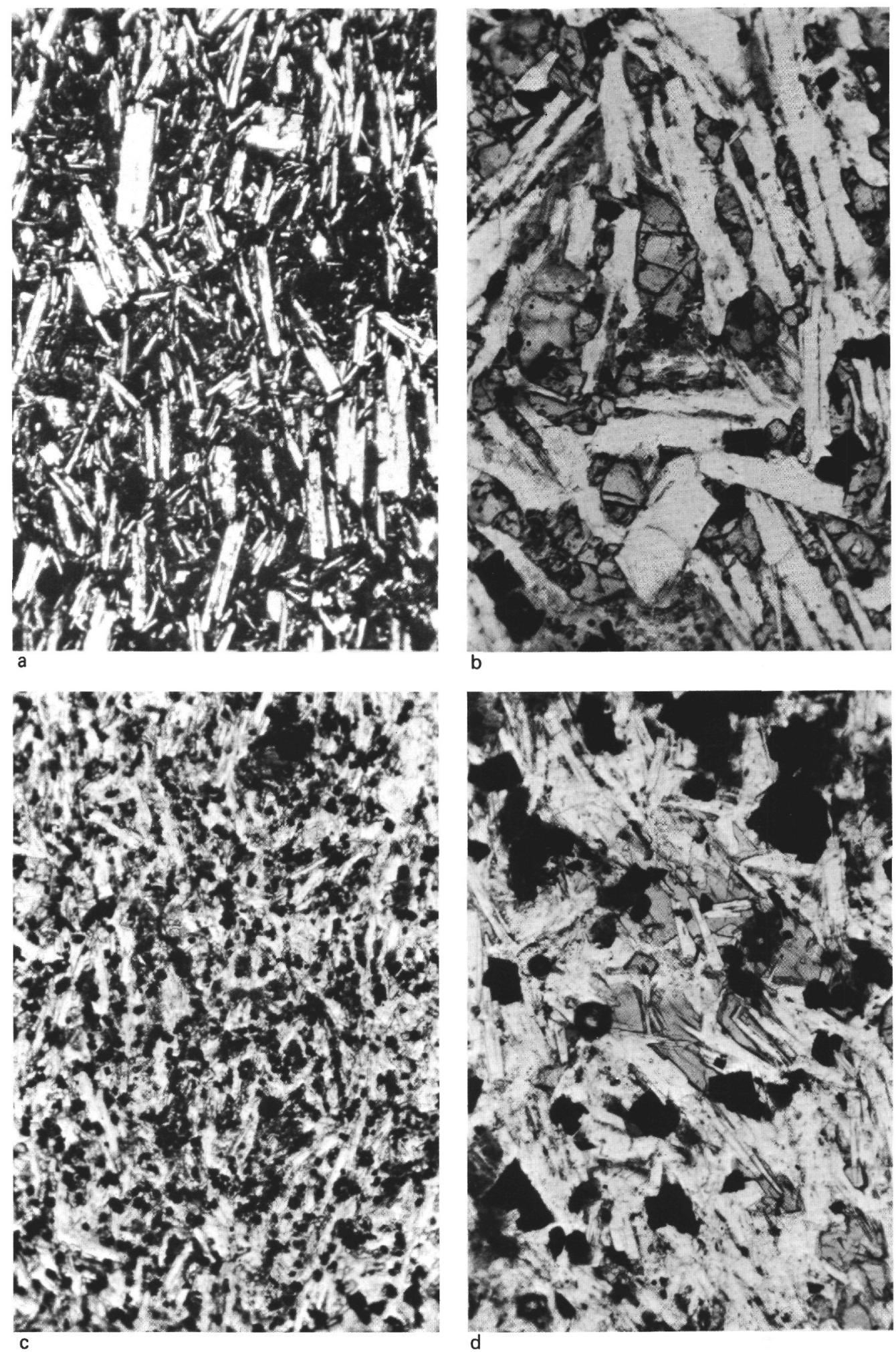

Figure 10. Photomicrographs of Site 432 volcanic rocks. A) Trachytic texture of hawaiite cobble, Sample 432A-1-1, 30-40 cm, in carbonate-cemented conglomerate overlying the volcanic sequence. Note serrate grain-size distribution. Crossed nicols. Length of field is $1.3 \mathrm{~mm}$. B) Intergranular texture in center of alkalic basalt flow, Sample 432A2-1, 83-85 $\mathrm{cm}$. Plate light. Length of field is $1.3 \mathrm{~mm}$. C) Fine-grained intergranular texture from near top of alkalic basalt flow, Sample 432A-3-2, 106-108 cm. Plane light. Length of field is $1.3 \mathrm{~mm}$. D) Ophitic texture from center of alkalic basalt flow, Sample 432A-5-2, 55-58 cm. Plane light. Length of field is $1.3 \mathrm{~mm}$. 


\section{R. J. KIRKPATRICK, D. A. CLAGUE, W. FREISEN}

TABLE 7

Petrographic Summary for Hole 432A Basalts

\begin{tabular}{|c|c|c|c|c|c|c|c|c|c|c|}
\hline \multirow[b]{2}{*}{$\begin{array}{l}\text { Core-Section, } \\
\text { Interval }(\mathrm{cm})\end{array}$} & \multirow[b]{2}{*}{$\begin{array}{l}\text { Flow } \\
\text { Unit }\end{array}$} & \multirow[b]{2}{*}{$\begin{array}{l}\text { Rock } \\
\text { Type }\end{array}$} & \multicolumn{3}{|c|}{ Phenocrysts \& Microphenocrysts } & \multicolumn{3}{|c|}{ Vesicles } & \multirow[b]{2}{*}{ Shape } & \multirow{2}{*}{$\begin{array}{c}\text { Groundmass } \\
\text { Per cent }\end{array}$} \\
\hline & & & Mineral & Per cent & $\begin{array}{l}\text { Average } \\
\text { Size } \\
(\mathrm{mm})\end{array}$ & Per cent & $\begin{array}{l}\text { Size } \\
\text { Range } \\
(\mathrm{mm})\end{array}$ & $\begin{array}{c}\text { Average } \\
\text { Size } \\
(\mathrm{mm})\end{array}$ & & \\
\hline $2-1,86-92.5$ & 1 & $\begin{array}{l}\text { Alkalic } \\
\text { Basalt }\end{array}$ & $\begin{array}{l}\mathrm{pl} \\
\text { ol }\end{array}$ & $\begin{array}{l}9 \\
2\end{array}$ & $\begin{array}{l}2.48 \\
0.54\end{array}$ & & & & & 89 \\
\hline $2-2,83-93$ & 2 & $\begin{array}{l}\text { Alkalic } \\
\text { Basalt }\end{array}$ & $\begin{array}{l}\text { pl } \\
\text { ol }\end{array}$ & $\begin{array}{l}10 \\
<1\end{array}$ & $\begin{array}{l}1.37 \\
1.00\end{array}$ & 6 & $0.10-1.11$ & 0.63 & $\begin{array}{l}\text { irregular- } \\
\text { elongated in } \\
\text { direction of } \\
\text { flow }\end{array}$ & 90 \\
\hline $2-3,37-43$ & 2 & $\begin{array}{l}\text { Alkalic } \\
\text { Basalt }\end{array}$ & $\begin{array}{l}\mathrm{pl} \\
\text { ol }\end{array}$ & $\begin{array}{r}16 \\
3\end{array}$ & $\begin{array}{l}2.63 \\
0.67\end{array}$ & 5 & $0.19-0.90$ & 0.51 & rounded & 81 \\
\hline $3-2,86-89$ & 3 & $\begin{array}{l}\text { Alkalic } \\
\text { Basalt }\end{array}$ & $\begin{array}{l}\mathrm{pl} \\
\text { ol }\end{array}$ & $\begin{array}{l}<1 \\
<1\end{array}$ & $\begin{array}{l}1.40 \\
0.50\end{array}$ & & & & & $99^{+}$ \\
\hline $3-2,120-126$ & 3 & $\begin{array}{l}\text { Alkalic } \\
\text { Basalt }\end{array}$ & ol & 1 & 1.40 & & & & & 99 \\
\hline $5-1,135-138$ & 4 & $\begin{array}{l}\text { Alkalic } \\
\text { Basalt }\end{array}$ & $\begin{array}{l}\text { ol } \\
\text { pl }\end{array}$ & $\begin{array}{l}1 \\
1\end{array}$ & $\begin{array}{l}0.84 \\
0.73\end{array}$ & & & & & $98^{+}$ \\
\hline $5-2,57-66$ & 4 & $\begin{array}{l}\text { Alkalic } \\
\text { Basalt }\end{array}$ & $\begin{array}{l}\mathrm{pl} \\
\mathrm{ol}\end{array}$ & $\begin{array}{r}<1 \\
2\end{array}$ & 0.55 & & & & & $97^{+}$ \\
\hline
\end{tabular}

Note: $\mathrm{pl}=$ plagioclase $; \mathrm{ol}=$ olivine $; \mathrm{cpx}=$ clinopyroxene $\mathrm{il}=$ ilmenite $; \mathrm{mt}=$ magnetite $; \mathrm{ap}=$ apatite $\mathrm{kf}=$ potash feldspar.

${ }^{a}$ By modal analysis of ordinary thin sections. Magnetite distinguished from ilmenite by shape. All percentages corrected for lowtemperature alteration.

${ }^{b}$ Smectite A is expandable on gly colation. Smectite B is only partially expandable on glycolation. Chlorite is not expandable.

Other Work: $W=$ wet chemical analysis

$\mathrm{X}=\mathrm{X}$-ray fluorescence for majors

$P=$ microprobe for majors (Bence et al.)

$\mathrm{T}=\mathrm{X}$-ray fluorescence for trace elements

$\mathrm{R} 1=\mathrm{INAA}$ for rare earths and trace elements (Clague and Frey)

$\mathrm{R} 2$ = ES for rare earths and trace elements (Bence et al.)

$\mathrm{S}=\mathrm{Sr}$ isotopic analysis (Lanphere et al.)

$\mathrm{K}=\mathrm{K}-\mathrm{Ar}$ ages (Dalrymple et al.)

$\mathrm{M}=$ microprobe mineral analyses (Clague et al.) 
TABLE 7 - Continued

\begin{tabular}{|c|c|c|c|c|c|c|}
\hline \multirow[b]{2}{*}{$\begin{array}{l}\text { Dominant } \\
\text { Texture }\end{array}$} & \multirow[b]{2}{*}{$\begin{array}{l}\text { Size Range } \\
\text { (mm) }\end{array}$} & \multicolumn{2}{|c|}{ Groundmass } & \multirow[b]{2}{*}{ Opaque Minerals } & \multirow[b]{2}{*}{ Alteration and Remarks ${ }^{b}$} & \multirow[b]{2}{*}{ Other Work } \\
\hline & & Minerals ${ }^{a}$ & Per cent & & & \\
\hline sub-ophitic & $\begin{array}{ll}0.10 & -2.30 \\
0.02 & -0.50 \\
0.005 & -0.10 \\
0.06 & -0.42 \\
0.05 & -0.20 \\
0.01 & -0.19\end{array}$ & $\begin{array}{l}\text { pl } \\
\text { cpx } \\
\text { mt } \\
\text { ol } \\
\text { ap } \\
\text { il }\end{array}$ & $\begin{array}{r}52 \\
25 \\
6 \\
4 \\
1 \\
1\end{array}$ & Equant timag. rare pyrite & $\begin{array}{l}25 \% \text { altered, ol completely } \\
\text { replaced by iddingsite and } \\
\text { smectite. Smectite has } \\
\text { basal } d=14.24 \AA \text { which ex- } \\
\text { pands to } 17.31 \AA \text { after } \\
\text { glycol. Both smectite A } \\
\text { and B are abundant. Mt } \\
\text { partly replaced by hematite. }\end{array}$ & $\mathrm{X}, \mathrm{P}, \mathrm{T}, \mathrm{R} 2, \mathrm{M}$ \\
\hline $\begin{array}{l}\text { subtrachytic } \\
\text { glomerophyric }\end{array}$ & $\begin{array}{ll}0.05 & -5.00 \\
0.10 & -0.67 \\
0.05 & -0.50 \\
0.01 & -0.10 \\
0.05 & -0.10 \\
0.02 & -0.21\end{array}$ & $\begin{array}{l}\text { pl } \\
\text { cpx } \\
\text { ol } \\
\text { mt } \\
\text { ap } \\
\text { il }\end{array}$ & $\begin{array}{r}52 \\
19 \\
8 \\
8 \\
1 \\
1\end{array}$ & & $\begin{array}{l}16 \% \text { altered, ol completely } \\
\text { replaced by iddingsite. } \\
\text { Smectite has basal } d= \\
13.38 \AA \text { which expands to } \\
16.98 \AA \text { after glycol. Only } \\
\text { a minor amount of smec- } \\
\text { tite A is present. Some mt } \\
\text { partly replaced by hema- } \\
\text { tite. Vesicles have botry- } \\
\text { oidal clay linings. }\end{array}$ & \\
\hline $\begin{array}{l}\text { microlitic } \\
\text { intergranular }\end{array}$ & $\begin{array}{ll}0.02 & -3.30 \\
0.03 & -0.50 \\
0.05 & -0.50 \\
0.01 & -0.10 \\
0.01 & -0.30 \\
0.03 & -0.25\end{array}$ & $\begin{array}{l}\mathrm{pl} \\
\mathrm{cpx} \\
\text { ol } \\
\mathrm{mt} \\
\mathrm{ap} \\
\text { il }\end{array}$ & $\begin{array}{r}49 \\
21 \\
4 \\
4 \\
2 \\
1\end{array}$ & Equant timag. & $\begin{array}{l}12 \% \text { altered, ol completely } \\
\text { replaced by iddingsite, } \\
\text { smectite and calcite. Smec- } \\
\text { tite has basal } d=16.98 \AA \\
\text { after glycol. Only a minor } \\
\text { amount of smectite } \mathrm{A} \text { is } \\
\text { present. Vesicles gen- } \\
\text { erally filled with yellow } \\
\text { smectite. }\end{array}$ & $\begin{array}{l}\mathrm{X}, \mathrm{P}, \mathrm{T}, \mathrm{R} 2, \mathrm{~S}, \\
\mathrm{~K}, \mathrm{M}\end{array}$ \\
\hline intergranular & $\begin{array}{c}0.05-0.41 \\
0.01-0.10 \\
(0.01)^{2} \\
0.01-0.42\end{array}$ & $\begin{array}{l}\mathrm{pl} \\
\mathrm{cpx} \\
\mathrm{mt} \\
\mathrm{ol}\end{array}$ & $\begin{array}{r}53 \\
29 \\
11 \\
6\end{array}$ & & $\begin{array}{l}5 \% \text { aitered, ol is } 80-85 \% \\
\text { replaced by olive green } \\
\text { smectite. Smectite has } \\
\text { basal } d=14.48 \AA \text { which } \\
\text { splits to form } 2 \text { peaks, } \\
d=14.48 \AA \text { (chlorite?) and } \\
d=17.31 \AA \text {. Only chlorite(?) } \\
\text { and smectite B are present. }\end{array}$ & \\
\hline $\begin{array}{l}\text { microlitic, } \\
\text { intergranular }\end{array}$ & $\begin{array}{l}0.02-0.50 \\
0.008-0.10 \\
0.002-0.20 \\
0.05-0.50 \\
0.01-0.10\end{array}$ & $\begin{array}{l}\mathrm{pl} \\
\mathrm{cpx} \\
\mathrm{mt} \\
\text { ol } \\
\text { il }\end{array}$ & $\begin{array}{r}58 \\
28 \\
10 \\
1 \\
2\end{array}$ & $\begin{array}{l}\text { Equant timag. Both } \\
\text { pyrite and chalco- } \\
\text { pyrite are present. }\end{array}$ & $\begin{array}{l}\sim 2 \% \text { al tered, ol is } 40 \% \text { re- } \\
\text { placed by olive green smec- } \\
\text { tite. Smectite has basal } \\
d=14.48 \AA \text { that expands to } \\
17.31 \AA \text { after glycol. Only } \\
\text { smectite B and chlorite (?) } \\
\text { are present. Rare phillip- } \\
\text { site in groundmass. }\end{array}$ & $\begin{array}{l}\mathrm{X}, \mathrm{P}, \mathrm{T}, \mathrm{R} 2, \mathrm{~S}, \\
\mathrm{~K}, \mathrm{M}\end{array}$ \\
\hline $\begin{array}{l}\text { subtrachytic, } \\
\text { ophitic }\end{array}$ & $\begin{array}{l}0.02-0.73 \\
0.01-0.10 \\
0.05-0.50 \\
0.005-0.40 \\
0.005-0.40 \\
0.01-0.40\end{array}$ & $\begin{array}{l}\mathrm{pl} \\
\mathrm{cpx} \\
\text { ol } \\
\mathrm{mt} \\
\text { il } \\
\text { ap }\end{array}$ & $\begin{array}{r}54 \\
23 \\
11 \\
7 \\
2 \\
2\end{array}$ & & $\begin{array}{l}24 \% \text { altered, ol is } 80-85 \% \\
\text { replaced by olive green } \\
\text { smectite. Smectite has } \\
\text { basal } d=14.48 \AA \text { that ex- } \\
\text { pands to } 17.31 \AA \text { after } \\
\text { glycol. Only smectite B } \\
\text { and chlorite(?) are present. }\end{array}$ & \\
\hline $\begin{array}{l}\text { subtrachy tic, } \\
\text { ophitic }\end{array}$ & $\begin{array}{ll}0.05 & -0.71 \\
0.01 & -0.25 \\
0.01 & -0.50 \\
0.005 & -0.25 \\
0.01 & -0.20\end{array}$ & $\begin{array}{l}\mathrm{pl} \\
\mathrm{cpx} \\
\text { ol } \\
\mathrm{mt} \\
\text { il }\end{array}$ & $\begin{array}{r}52 \\
24 \\
13 \\
4 \\
4\end{array}$ & $\begin{array}{l}\text { Timag. Ilmenite may be } \\
\text { present as very tiny } \\
\text { elongate crystals. Pyrite } \\
\text { is present and the olivine } \\
\text { phenocrysts contain } \\
\text { rare chromite. }\end{array}$ & $\begin{array}{l}13 \% \text { altered, ol is } 90 \% \text { re- } \\
\text { placed by olive green smec- } \\
\text { tite. Smectite has basal } \\
d=14.48 \AA \text { that expands to } \\
17.31 \AA \text { after glycol. Only } \\
\text { smectite B and chlorite(?) } \\
\text { are present. }\end{array}$ & $\mathrm{X}, \mathrm{T}, \mathrm{M}, \mathrm{S}, \mathrm{K}$ \\
\hline
\end{tabular}

\section{SITE 433}

Site 433 was drilled into a lagoonal sediment pond on the northwest side of Suiko seamount at $44^{\circ} 46.63^{\prime} \mathrm{N}$, $170^{\circ} 01.23^{\prime} \mathrm{E}$. It is the major site of Leg 55 , and the material available for study is far more extensive than for Site 430 and 432. Three holes - 433A, 433B, and $433 \mathrm{C}$ - reached volcanic basement and $433 \mathrm{C}$ penetrated about 387 meters of volcanic material. This is the longest section to be studied in detail in the entire Hawaiian-Emperor chain. As discussed in the Site
Chapter for Site 433 (Leg 55 Scientific Staff, this volume), there are 67 numbered volcanic units in Hole $433 \mathrm{C}$, and probably 114 individual lava flows. All are subaerial. Most of these that are reasonably fresh have been analyzed either on board the Challenger or after the cruise.

\section{Chemistry and Classification}

The rocks recovered at Site 433 are all alkalic basalts, tholeiitic basalts, or tholeiitic picrites. Table 8 presents 
the post-cruise major-element analyses both as received and dry-reduced, along with CIPW norms assuming $\mathrm{Fe}^{+3} / \mathrm{Fe}^{+3}+\mathrm{Fe}^{+2}=0.15$. Table 9 presents the postcruise trace-element data. In general, these data are for the least-altered samples available, and are usually from relatively massive flow interiors. Figure 2 presents the total alkalis versus silica data, Figure 11 gives $\mathrm{MgO}$ variation diagrams, and Figure 12 shows the chemical variation with depth in the hole for the Site 433 volcanic rocks.

The top three flow units (1 through 3 ) are alkali basalts (Figure 2) that are very similar. They also have similar magnetic inclinations, and may well be genetically related.

We have classified the rest of the flows as tholeiitic picrites (oceanites) or tholeiitic basalts. Most of these fall well within the tholeiitic field on the plot of total alkalis versus silica. Those that fall on the alkali side of the dividing line usually have very high $\mathrm{K}_{2} \mathrm{O}$ contents. The X-ray diffraction work (appendix, following this chapter) indicates that at least some of these samples contain phillipsite. Their apparent alkali nature, then, is a result of secondary alteration. Rare-earth-element patterns (Clague and Frey, this volume) and pyroxene chemistry (Clague et al., this volume) indicate that all the flows examined below Flow Unit 3 are best classified as tholeiitic.

\section{Petrography}

The appendix following this chapter presents the modal mineralogy, the modal percentage of alteration minerals, the $d$-spacings of the clays, the olivine replacement, the nature and amount of vesicle filling (usually clay and zeolite), and the presence or absence of carbonate in each Site 433 thin section examined. Figure 13 presents the modal phenocryst mineralogy versus depth for the samples examined.

The three alkalic flows contain olivine, clinopyroxene, and plagioclase phenocrysts in varying but approximately equal proportions.

The groundmass minerals in the alkalic flows are olivine, clinopyroxene, plagioclase, titanomagnetite, apatite, and clay after glass. Most of the olivine is altered to clay or iddingsite, although some is fresh. The textures in the alkalic basalts are subtrachytic, and vary from intergranular near flow margins to sub-ophitic in flow centers. Figure 14 illustrates the textural variation.

The tholeiitic basalts and picrites usually have only olivine phenocrysts or olivine, clinopyroxene, and plagioclase phenocrysts. A few are essentially aphyric or have only olivine and plagioclase, olivine and clinopyroxene, or clinopyroxene and plagioclase. The groundmass minerals invariably include olivine, clinopyroxene, plagioclase, titanomagnetite, ilmenite, sulfide blebs, and clay after glass. Only a few (Samples 433C-24-7, $133-139 \mathrm{~cm}, 37-3,79-87 \mathrm{~cm}$, and $39-5,87-94 \mathrm{~cm}$ ) contain, in addition, groundmass or microphenocryst pigeonite. The textures in the tholeiites vary from interstitial to intergranular to sub-ophitic. The flow tops and bottom must originally have been nearly all glass. Figure 14 illustrates typical textures.

\section{Alteration}

The Site 433 basalts vary from almost fresh (only interstitial glass altered to clay) to extensively altered. The alkalic basalts are less altered than the tholeiites. As at Sites 430 and 432, the plagioclase and clinopyroxene are usually unaltered. The titanomagnetite, expecially in the tholeiites, has usually undergone oxidation exsolution of ilmenite. The groundmass glass and most of the olivine is altered to saponitic clay. Some of the olivine is fresh and some has altered to iddingsite.

\section{Stratigraphy}

Hole $433 \mathrm{C}$ is the only hole drilled on Leg 55 which penetrated deep enough to compare the sequence of lava types with the standard Hawaiian sequence, and it appears that the Hole $433 \mathrm{C}$ sequence is similar to many exposed Hawaiian sequences. The top few flows are alkalic basalts and the lower bulk of the volcano is tholeiitic. Pyroxene and feldspar chemistry (Clague et al., this volume) indicates that the alkalic basalts belong to the caldera-filling stage or post-caldera stage and not the post-erosional stage. No flows in any of the Leg 55 holes have been identified as post-erosional.

Within the tholeiitic sequence the flows can be divided into 25 stratigraphically, chemically, and mineralogically coherent groups consisting of from one to six flows. Chemically these groups can best be distinguished on plots of $\mathrm{Zr}$, a magmatophile element, versus $\mathrm{Ni}$, which preferentially enters olivine (Figure 15 ). They can also be distinguished on plots of $\mathrm{TiO}_{2}$ versus $\mathrm{MgO}$ (Figures 16 and 17). Table 10 lists the groups, along with their flow units, depths and core intervals, phenocryst mineralogy, chemical type, and the magnetic units (see 433 Site Report, this volume). Figure 12 illustrates the positions of the groups on plots of $\mathrm{TiO}_{2}$ and $\mathrm{MgO}$ versus depth.

The $\mathrm{Ni}$ and $\mathrm{MgO}$ variation diagrams indicate that there are two kinds of tholeiitic basalt: those with relatively high $\mathrm{TiO}_{2} / \mathrm{MgO}$ and $\mathrm{Zr} / \mathrm{Ni}$ (high- $\mathrm{Zr}$ type) and those with relatively low $\mathrm{TiO}_{2} / \mathrm{MgO}$ and $\mathrm{Zr} / \mathrm{Ni}$ (low- $\mathrm{Zr}$ type). These two types correspond to the high-and low$\mathrm{La} / \mathrm{MgO}$ types of Clague and Frey (this volume). The two types are interbedded throughout the section, sometimes flow by flow, sometimes in longer sequences.

The low-Zr type is more abundant, and includes both olivine phyric basalts and picrites and more differentiated olivine, clinopyroxene, and plagioclase phyric basalts. Clinopyroxene and plagioclase phenocrysts first appear in any abundance at about 8 per cent $\mathrm{MgO}$.

The high-Zr type is dominated by olivine phyric basalts and picrites. Only three flows (27, 35, and 64) contain olivine, clinopyroxene, and plagioclase phenocrysts, and one (19a) contains olivine and clinopyroxene. $\mathrm{MgO}$ content in Flow Unit 35 is 10.44 per cent; in the other multiply saturated flows it is less. Phenocryst clinopyroxene and plagioclase free flows occur to $\mathrm{MgO}$ values as low as 8.8 per cent. It does appear, though, that clinopyroxene and plagioclase phenocrysts occur at 

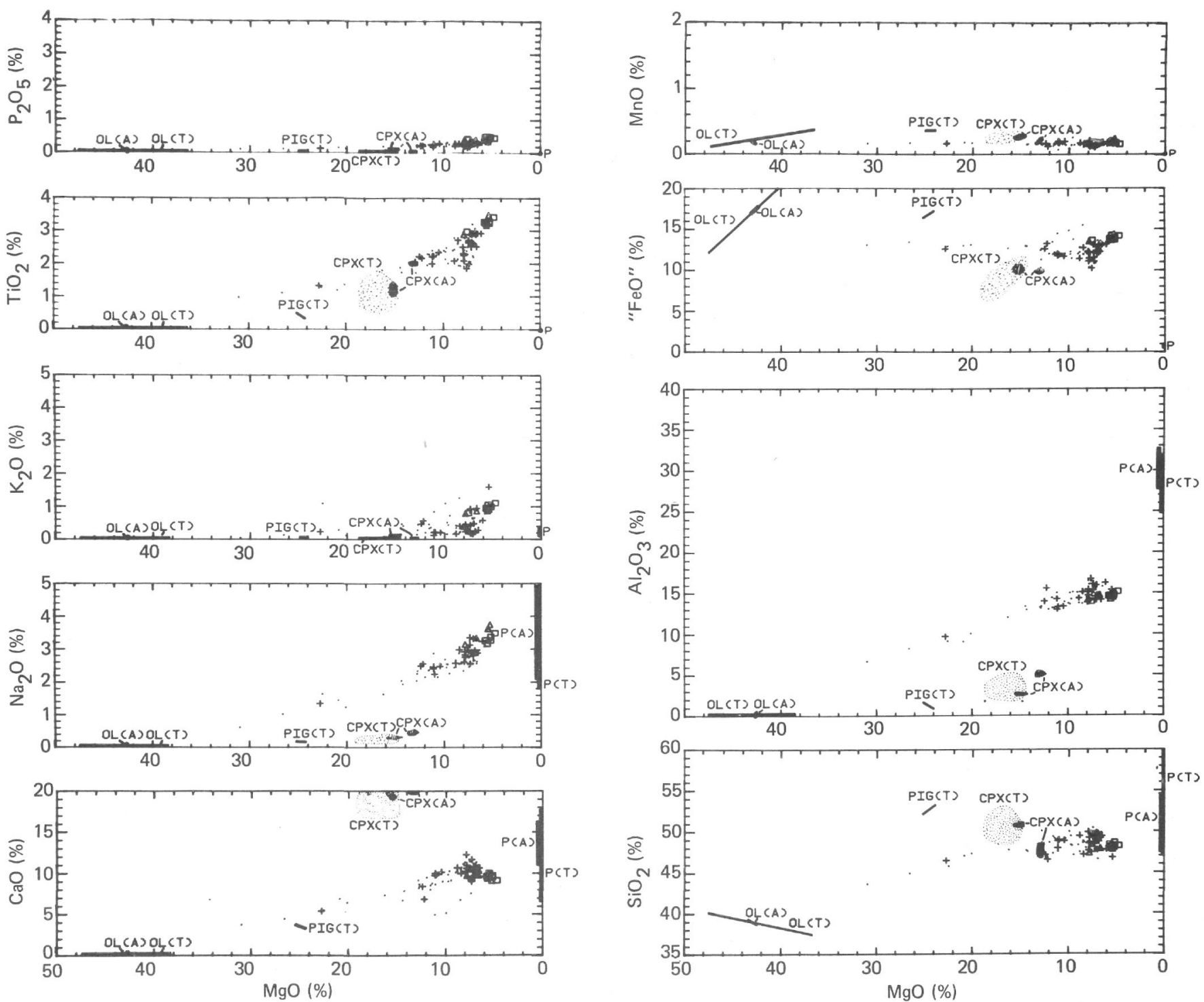

Figure 11. $\mathrm{MgO}$ variation diagrams for Site 433 volcanic rocks, including phenocryst compositions (Clague et al., this volume). 

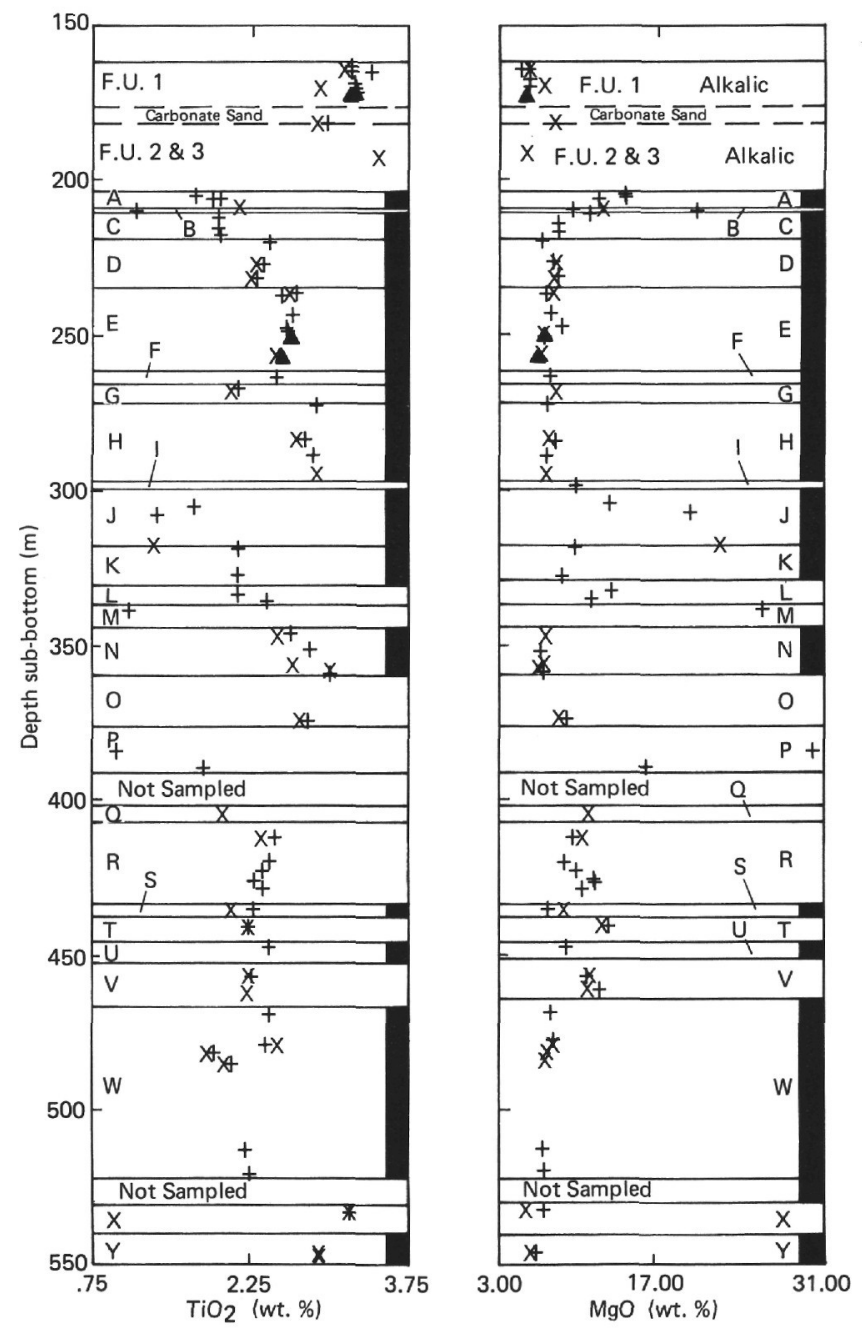

Figure 12. Stratigraphy and chemical variation of $\mathrm{TiO}_{2}$ and $\mathrm{MgO}$ within the Hole $433 \mathrm{C}$ volcanic sequence. Stratigraphic units correspond to those in Figures 15 and 16. Blackband indicates low- $\mathrm{Zr}$ tholeiite type, white band indicates high-Zr type; except for the three alkalic flows at the top. $+=$ shipboard analysis, and $\times=$ shorebased analysis. 

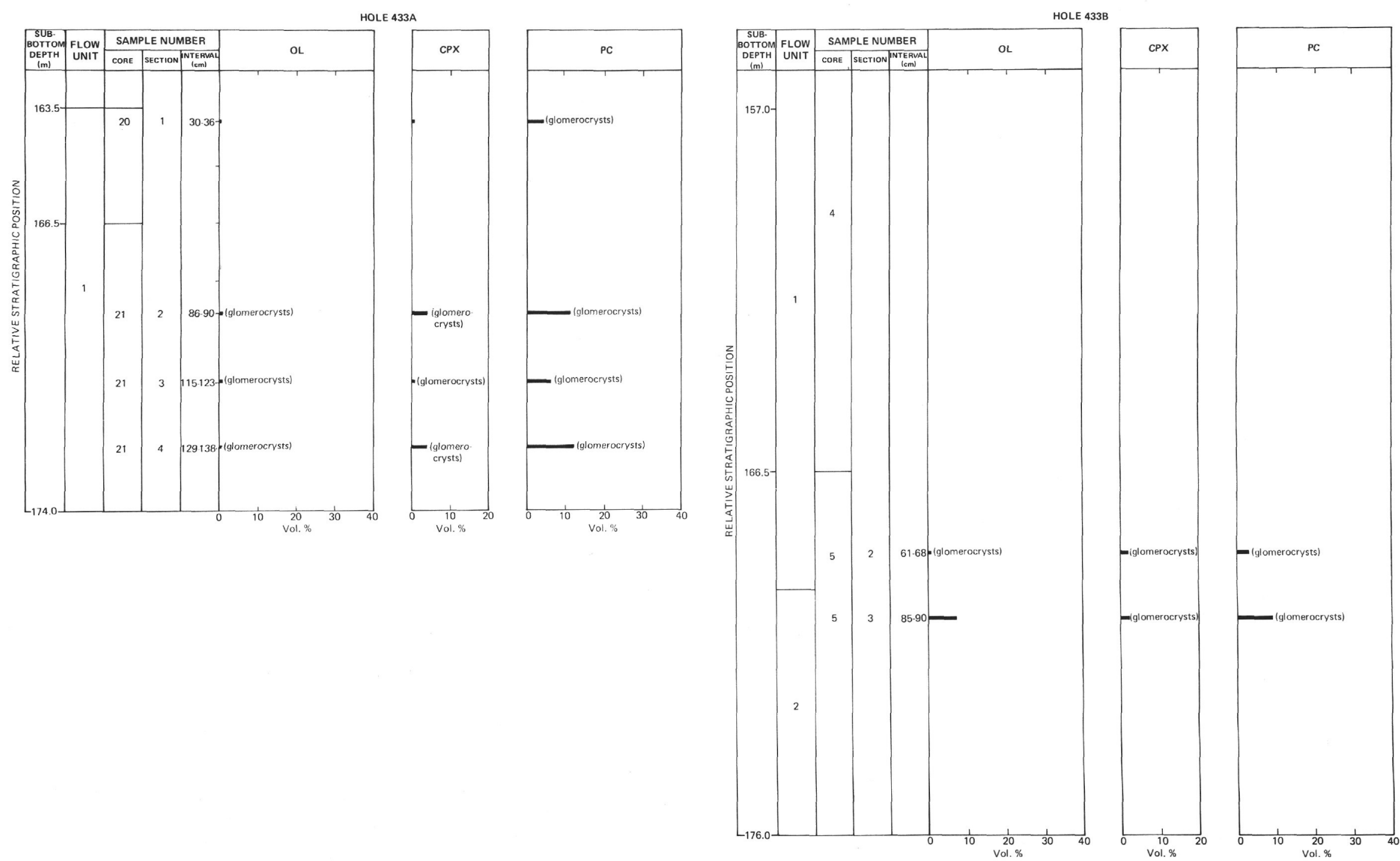

Figure 13. Downhole variation in phenocryst mineralogy for Hole $433 A$ volcanic rocks from Hole (a) $433 A$, (b) $433 B$, and (c) $433 C$. 

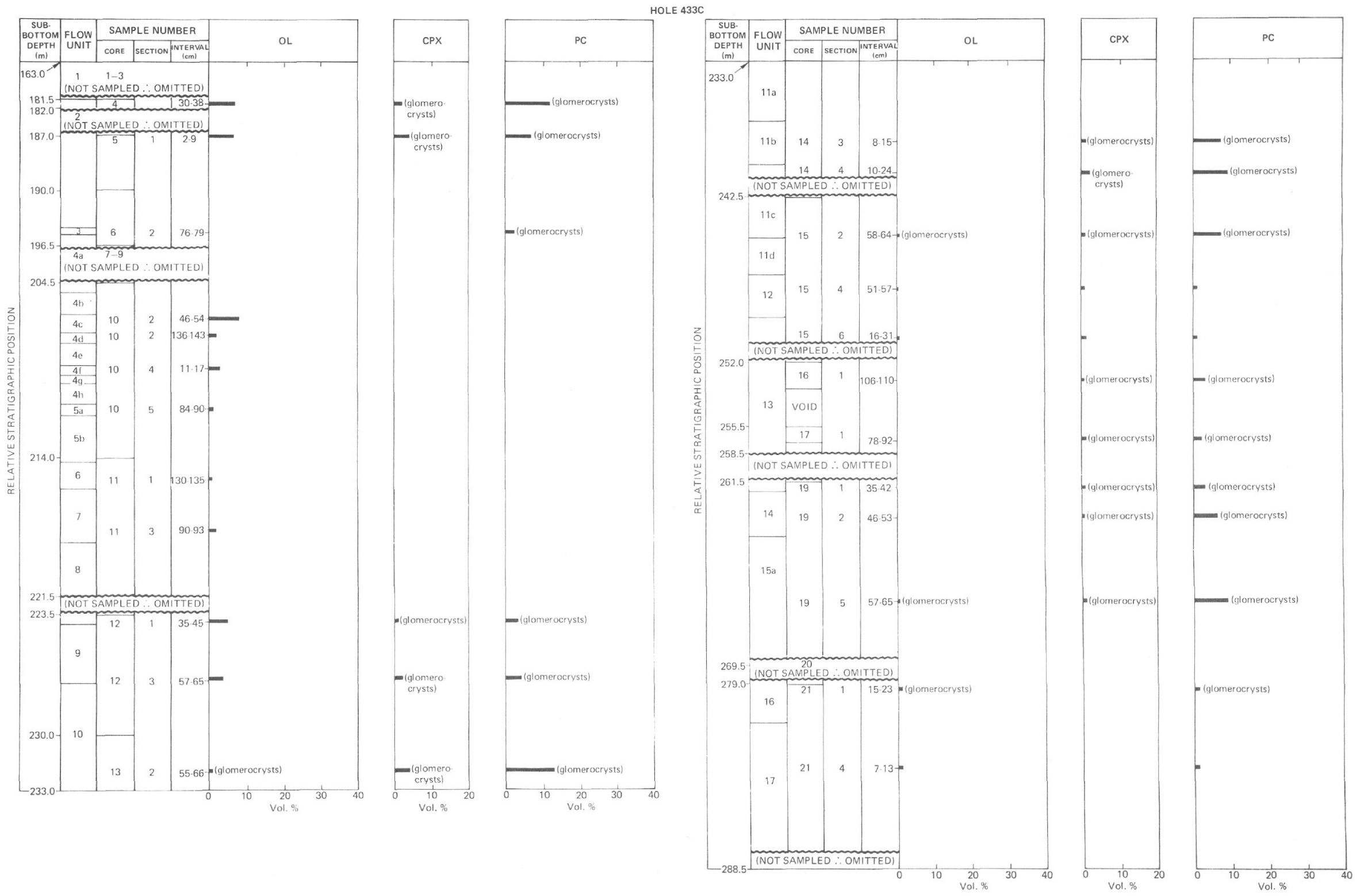

Figure 13. (Continued). 

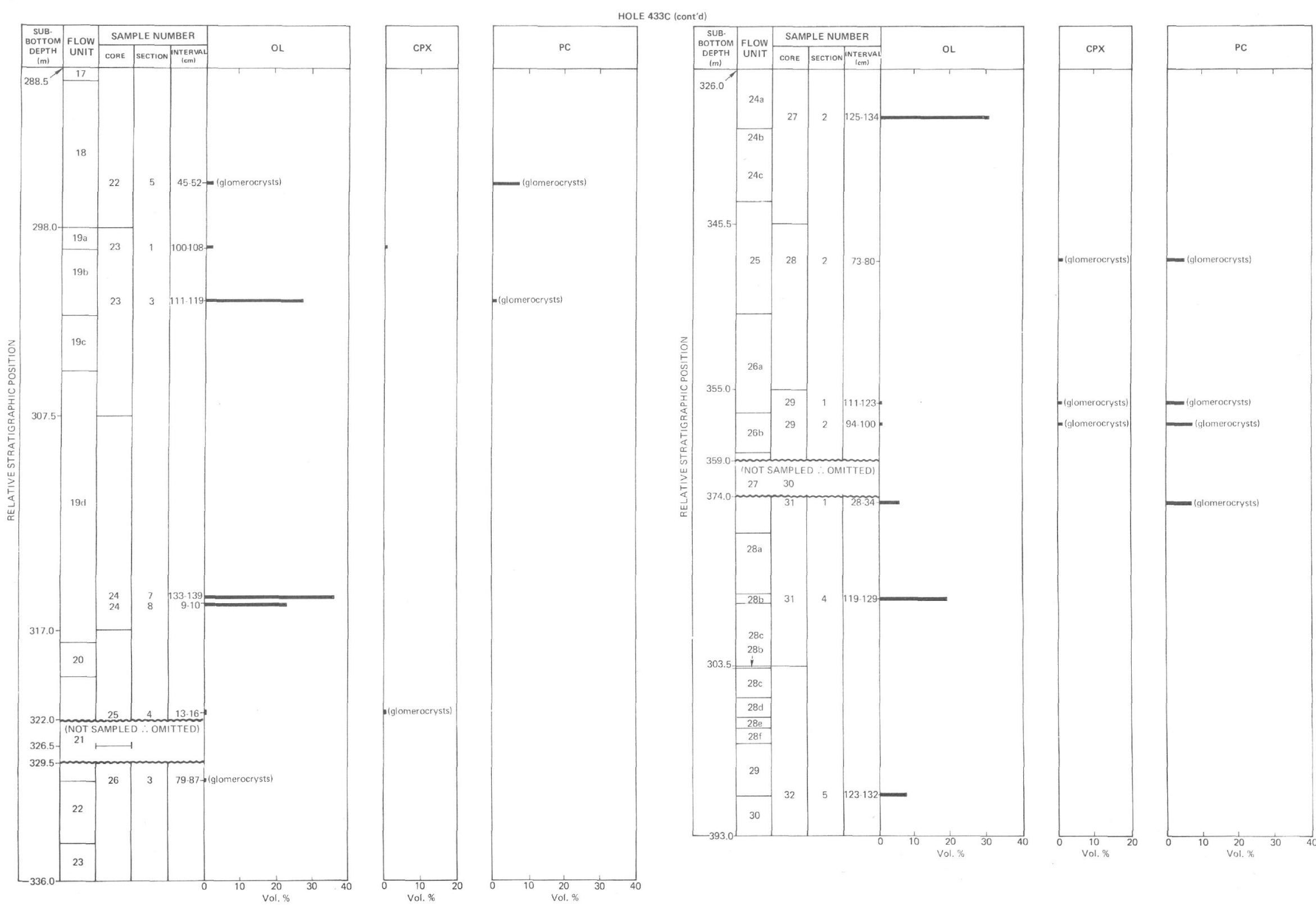

Figure 13. (Continued). 

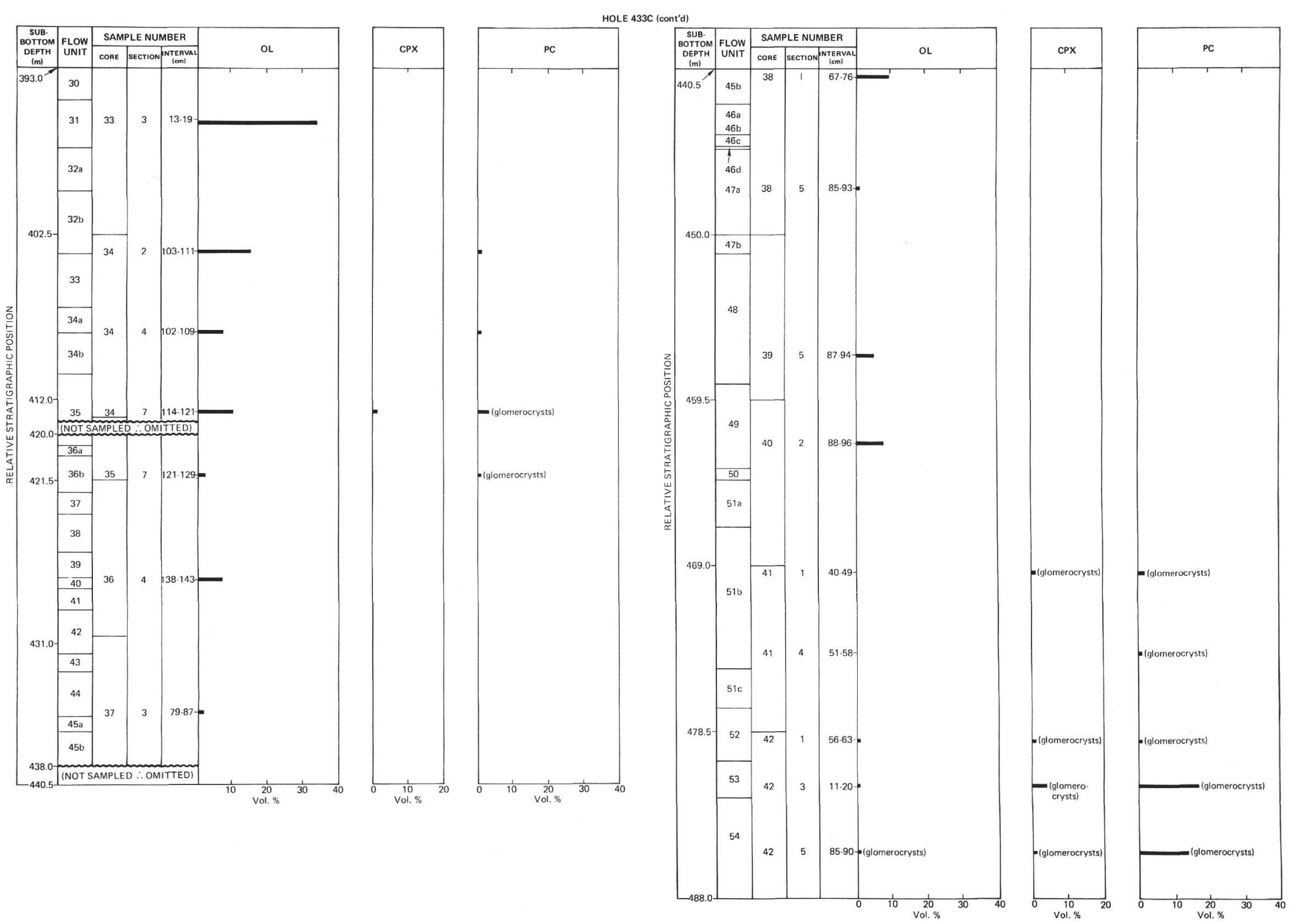

Figure 13. (Continued). 


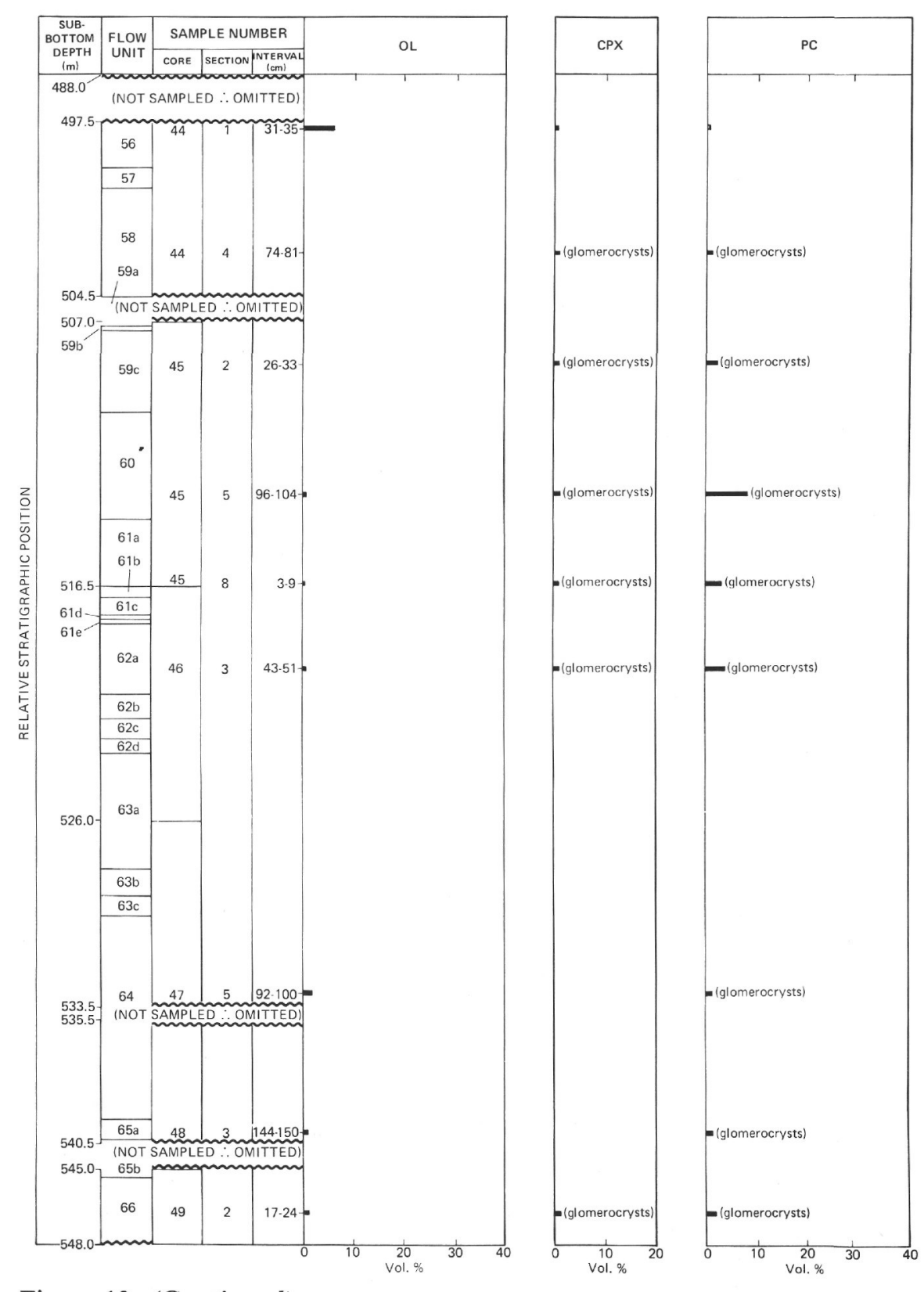

Figure 13. (Continued). 

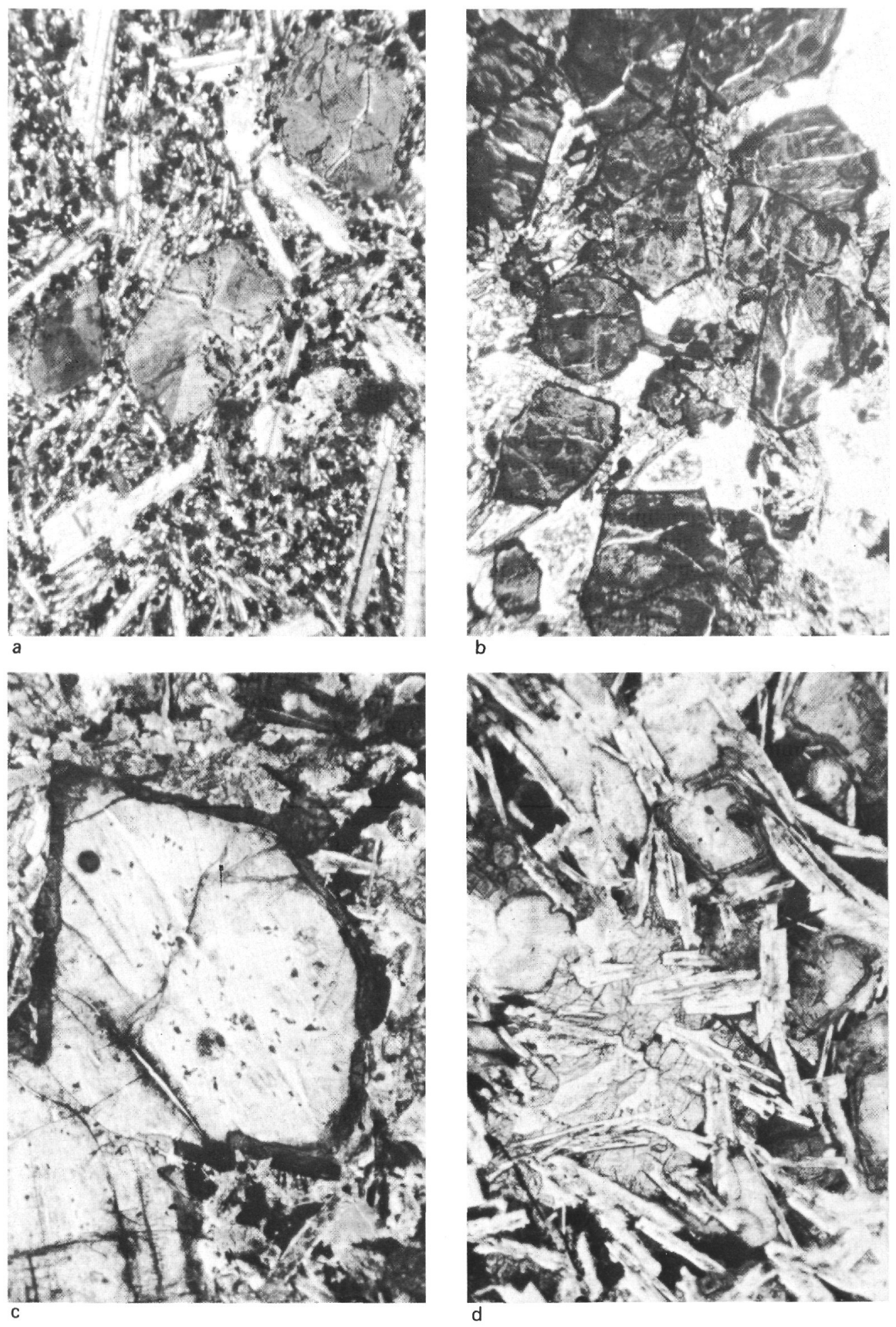

Figure 14. Photomicrographs of Site 433 basalts. A) Sector-zoned pyroxene microphenocryst in intergranular textured alkalic basalt, Sample 433A-5-2, 83-85 cm. Plane light. Length of field is $1.3 \mathrm{~mm}$. B) Cumulate olivine phenocrysts in picritic tholeiite. Rims of olivines are iddingsitized, centers are replaced by clay. Sample 433C-10-4, 118-120 $\mathrm{cm}$. Plane light. Length of field is $4.9 \mathrm{~mm}$. C) Cumulate olivine phenocryst in picritic tholeiite, showing iddingsitized rim and center altered to clay. Sample 433C-10-2, 15 $18 \mathrm{~cm}$. Plane light. Length of field is $1.3 \mathrm{~mm}$. D) Ophitic texture in groundmass of tholeiitic basalt. Note groundmass olivine grain with iddingsitized rim and clay center. Sample 433C-26-6, 109-112 cm. Plane light. Length of field is $1.3 \mathrm{~mm}$. 


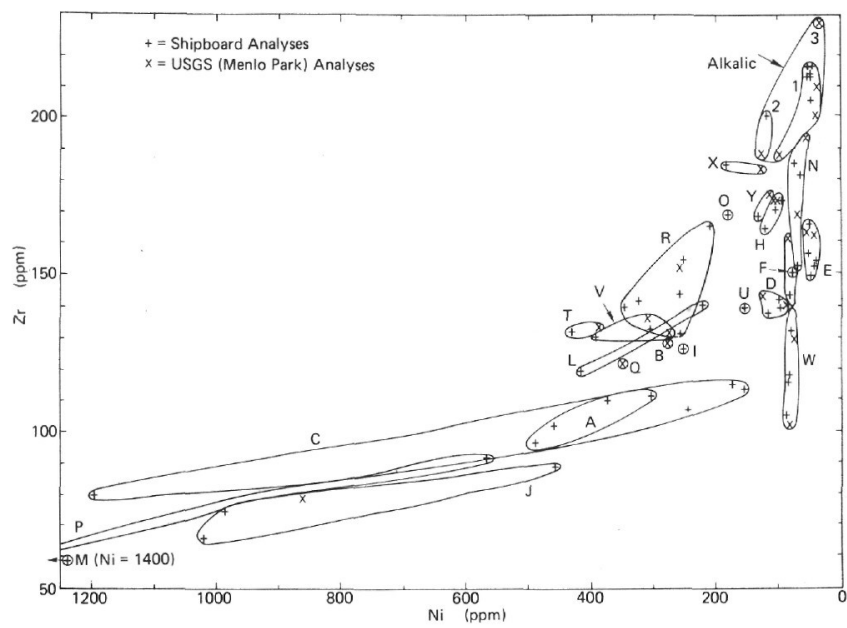

Figure 15. Zr-Ni variation diagram for Site 433 tholeiitic basalts. Each group $(A-Y)$ is chemically, mineralogically, and stratigraphically coherent.

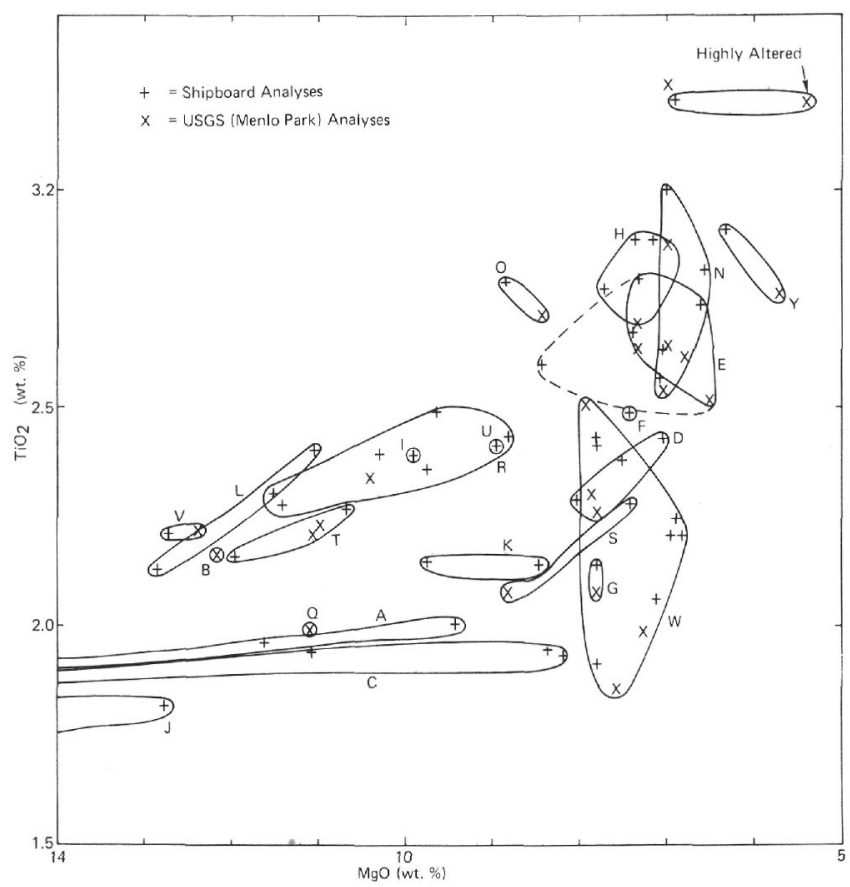

Figure 16. $\mathrm{TiO}_{2}-\mathrm{MgO}$ variation diagram for Site 433 tholeiitic basalts. The groups are the same as defined by $\mathrm{Zr}$-Ni (Figure 15). 

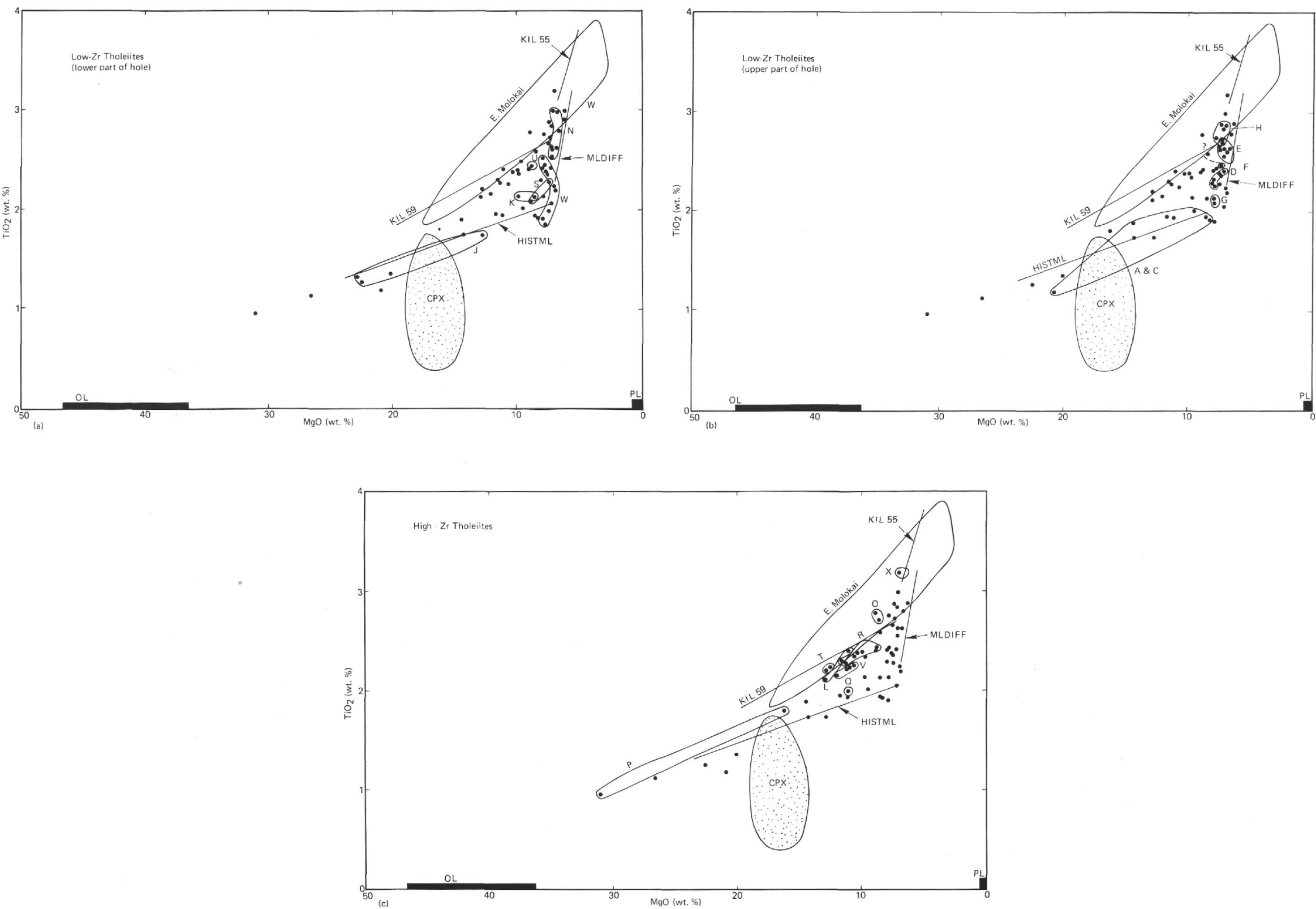

Figure 17. Comparison of $\mathrm{TiO}_{2}-\mathrm{MgO}$ compositional trends for tholeiitic basalts at Suiko Seamount (Site 433), Kilauea olivine-controlled trend (KIL59), Kilauea differentiated trend (KIL55), Mauna Loa olivine-controlled trend (HISTML), Mauna Loa differentiated trend (MLDIFF), and East Molokai trend. Suiko stratigraphic groups identified in Table 11 are indicated by lettered fields. Stippled field labeled CPX encloses clinopyroxene phenocryst compositions (Clague et al., this volume). a) and b) Suiko low-Zr types, c) Suiko high-Zr types. 
higher $\mathrm{MgO}$ values for the high-Zr type than for the low-Zr type.

It is not clear whether these two types of tholeiite are the product of one volcano alternately erupting two different types of lava or of two neighboring volcanoes contemporaneously erupting different lavas. The position of Site 433 on a neck between the main part of Suiko seamount and a northwestward projection which is quite likely a separate volcano (see 433 Site Report, this volume) suggests that we may have sampled a region of overlap between two volcanoes.

The occurrence of chemical and mineralogical groups within this sequence of flows is similar to the situation on East Molokai (Beeson, 1976), although the rock types and apparent fractionation trends there are different from those at Site 433. The East Molokai section is 305 meters thick, and is the only other well-studied section in the Hawaiian-Emperor chain with a thickness comparable to that at Hole 433C. At both Site 433 and East Molokai, the chemical variation within each group of one to a few flows is quite small with, perhaps, some indication of more fractionated compositions upward. At East Molokai, however, the overall trend for the entire section is toward more fractionated and alkali compositions upward. At Site 433 there is no overall trend. In addition, at East Molokai there appears to be a continuous trend from transitional tholeiitic compositions at the bottom to clearly alkalic compositions at the top. Beeson (1976) has proposed either high-pressure fractionation of aluminous pyroxene or varying partial fusion of mantle peridotite to account for this. At Site 433, the difference between the tholeiitic and alkalic basalts is much more distinct.

\section{Fractionation and Origin of Basalts}

Qualitatively, the overall compositional trends for the Site 433 tholeiitic basalts are similar to those observed on Kilauea and Mauna Loa volcanoes on the island of Hawaii (Wright, 1971; Wright and Fiske, 1971) and quite different from the trend for East Molokai (Beeson, 1976). As for most Hawaiian-Emperor chain suites, however, the trends are in detail different from any others. Figure 17 presents the compositional trends for the Site 433 tholeiites in terms of $\mathrm{TiO}_{2}-\mathrm{MgO}$, along with the Kilauea, Mauna Loa, and East Molokai trends. One of the Kilauea trends (KIL59) and the Mauna Loa trends (HISTML) are for olivine composition control (Wright, 1971). The other Kilauea trend (KIL55) involves olivine, clinopyroxene, and plagioclase (Wright and Fiske, 1971). The East Molokai trend apparently involves mantle processes (Beeson, 1976), although olivine, clinopyroxene, and plagioclase phenocrysts are present even in the most magnesian flows.

The compositions in the picrite and olivine phyric tholeiite groups from Site 433 - A and C (these two have similar magnetic inclinations and are probably related), J, P, R, and V - appear to be controlled by olivine alone. Although most of these flows are quite altered and their $\mathrm{MgO}$ content has probably been changed, their compositional trends extrapolate linearly back to the observed range of olivine phenocryst compositions. With two exceptions (Figure 18), these flows contain only olivine phenocrysts (up to $50 \%$ ), and the more magnesian ones probably represent olivine accumulation. (Clague and Frey, this volume). As at Kilauea (Wright, 1971), each picritic group has somewhat different $\mathrm{TiO}_{2}$ content for a given $\mathrm{MgO}$ content. This probably represents different depths of melting or a different mantle composition during the generation of each magma batch. The magnetic inclination within each picritic groups varies very little, indicating they were erupted within a short period (Kono, this volume). It seems likely that each is the result of a single magmatic event. Wright (1971) has shown that for Kilauea and Mauna Loa each of these magmatic events is the result of a new surge of magma entering the volcano from the mantle. At Kilauea in recent years, these events have occurred every few years (Wright, 1971). Given the small variation in magnetic inclination in the picrite groups, this may also have been the time scale for the duration of a magmatic event on Suiko.

As for the KIL55 trend (Wright and Fiske, 1971), the compositions of the olivine, clinopyroxene, and plagioclase phyric groups (D, E, F, G, H, I, K, N, O, U, W, $\mathrm{X}$, and $\mathrm{Y}$ ) probably reflect, in part, fractionation of these phases. It is highly unlikely, however, that the entire trend of these groups is a consequence of low-pressure fractionation of one or even a few parent magmas. As for the olivine phyric groups, the magnetic inclination in most of the multiply saturated groups varies little, indicating that the flows were erupted within a relatively few years. If the Kilauea model of Wright and Fiske (1971) is applicable, the chemical variation in each of these groups probably represents the effects of lowpressure processes (fractionation, magma mixing) superimposed on the initial composition of the magma as it came from the mantle. A few of the multiply saturated groups $(\mathrm{D}, \mathrm{E}, \mathrm{H}, \mathrm{N}, \mathrm{W})$ do contain major magnetic inclination breaks, implying major time gaps. The most likely explanations for this are that the source region produced magma of similar composition at different times or that shallow fractionation brought the magma compositon to the same point twice in succession.

There are also major breaks in magnetic inclination between many of the chemical groups. These major changes (indicated by slashes in Table 10) probably also reflect long time intervals between flows, perhaps many thousands of years (Kono, this volume). If the time scale of a few years for a magmatic event is applicable to Suiko, each stratigraphic group represents one, or possibly two (if there is a break in magnetic inclination), separate events involving injection of magma from the mantle into the volcano.

These changes in magnetic inclination do not necessarily imply that the volcano was quiet for thousands of years, however, since the drill penetrates only one spot and lava must have flowed in all directions over the volcano to build up the shield.

The exact origin of the chemical variation within each of the groups is difficult to evaluate. The rocks are so 
TABLE 8

Chemical Analyses and Norms of Volcanic Rocks from Site 433, Suiko Seamount

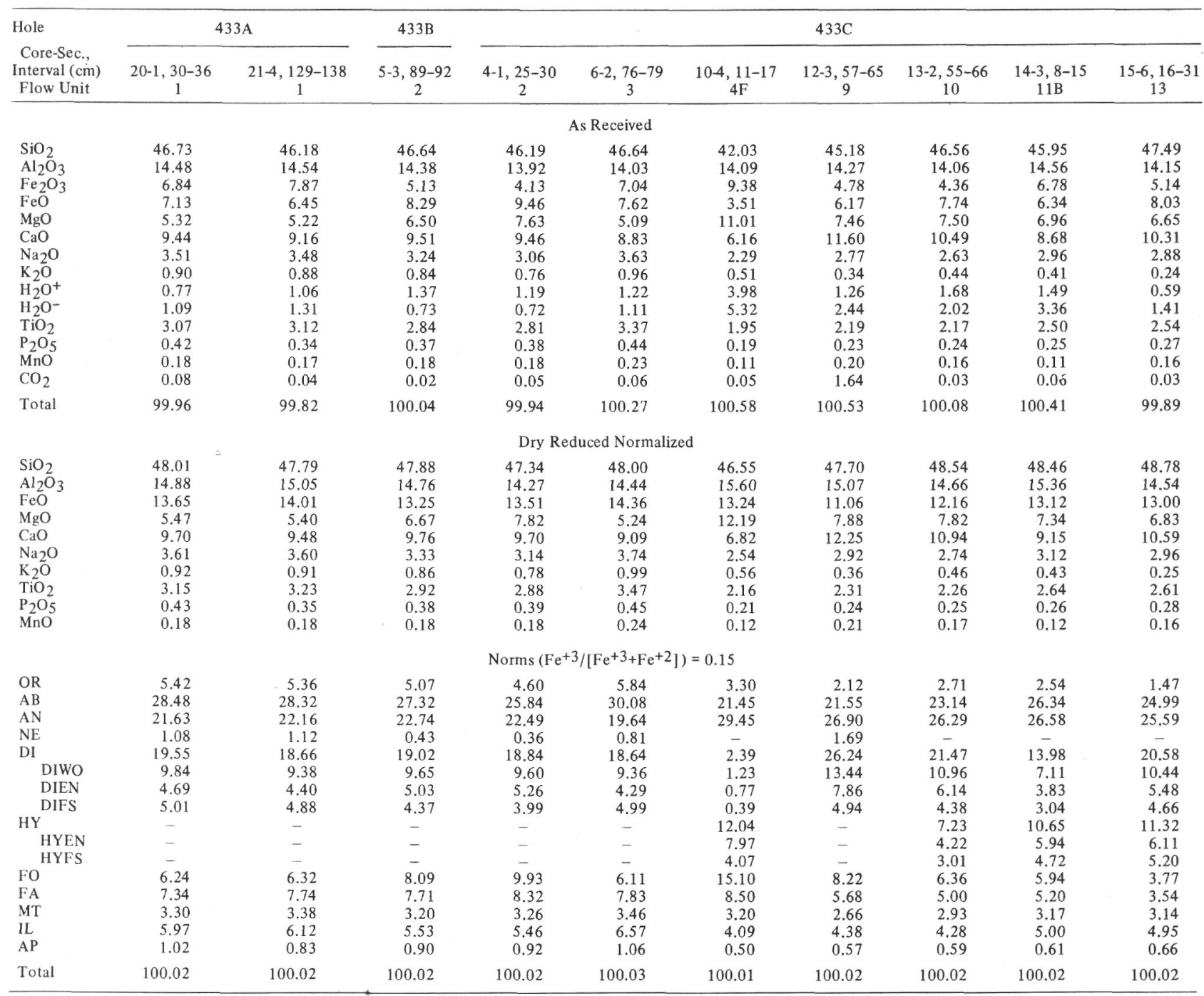

highly altered that quantitative fractionation or mixing calculations (Wright and Doherty, 1970) would not be useful. Wright and Fiske (1971), however, have shown that for the fractionated lavas of Kilauea volcano the chemical variation within lavas of a single eruptive phase (comparable, we postulate, to each of our chemical groups) results from fractionation of the observed phenocryst phases and, to some extent, mixing of magmas from different events. The compositional trends within each of the groups on Suiko is in qualitative agreement with these causes. The exact composition of each group, then, reflects a combination of the composition of the mantle-derived parent magma and the extent of low-pressure fractionation.

The differences between the low- $\mathrm{Zr}$ and high- $\mathrm{Zr}$ tholeiites appear to be more fundamental. In addition to differences in the incompatable-element concentrations at a given $\mathrm{MgO}$ or $\mathrm{Ni}$ value, the two types begin crystallizing plagioclase and pyroxene at different $\mathrm{MgO}$ values, the high- $\mathrm{Zr}$ type at higher values (Figure 18). The slope of the compositional trend for the multiple saturated samples is also less for the high-Zr type than for the low-Zr type, implying that olivine or pyroxene are more important relative to plagioclase for the high$\mathrm{Zr}$ type than they are for the low-Zr type. The origin of this difference is not clear. There appears to be no systematic difference in major-element oxides, includ$\mathrm{SiO}_{2}, \mathrm{Al}_{2} \mathrm{O}_{3}, \mathrm{FeO}$, and $\mathrm{CaO}$, which could account for this difference. The samples may, however, be so altered that subtle differences in one or more of these elements is masked by the alteration effects.

\section{COMPOSITIONAL VARIATION ALONG THE HAWAIIAN-EMPEROR CHAIN}

One of the major questions we set out to answer on Leg 55 was whether the compositions of the lavas erupted changed with position along the Hawaiian-Emperor chain. Knowledge of such change, if any, is essential to discussions of the long-term history of the Hawaiian hot spot, changes in the conditions of magma genesis, and changes in the source material from which the magma is derived. 
TABLE 8 - Continued

\begin{tabular}{|c|c|c|c|c|c|c|c|c|c|c|}
\hline & & & & $433 \mathrm{C}$ & & & $v$ & & & \\
\hline $\begin{array}{c}17-1,78-82 \\
13\end{array}$ & $\begin{array}{c}19-5,57-65 \\
15 \mathrm{~A}\end{array}$ & $\begin{array}{c}21-4,7-13 \\
17\end{array}$ & $\begin{array}{c}22-5,45-52 \\
18\end{array}$ & $\begin{array}{c}24-7,133-139 \\
19 \mathrm{D}\end{array}$ & $\begin{array}{c}28-2,73-80 \\
25\end{array}$ & $\begin{array}{c}29-1,112-123 \\
26 \mathrm{~A}\end{array}$ & $\begin{array}{c}29-2,94-100 \\
26 \mathrm{~B}\end{array}$ & $\begin{array}{c}29-1,28-34 \\
27\end{array}$ & $\begin{array}{c}34-2,103-111 \\
33\end{array}$ & $\begin{array}{c}34-7,114-121 \\
35\end{array}$ \\
\hline \multicolumn{11}{|c|}{ As Received } \\
\hline 48.83 & 47.33 & 46.67 & 46.31 & 43.30 & 48.02 & 48.02 & 47.49 & 46.32 & 45.26 & 46.66 \\
\hline 13.96 & 14.81 & 15.44 & 15.49 & 9.00 & 14.19 & 13.68 & 13.94 & 14.86 & 13.44 & 12.71 \\
\hline 3.06 & 4.15 & 6.03 & 4.95 & 3.36 & 3.69 & 3.25 & 6.38 & 3.52 & 7.60 & 5.20 \\
\hline 10.18 & 7.24 & 5.66 & 7.59 & 8.76 & 8.75 & 8.72 & 6.10 & 9.35 & 4.40 & 6.49 \\
\hline 6.44 & 7.54 & 7.04 & 6.78 & 21.21 & 6.89 & 6.79 & 6.42 & 8.29 & 10.48 & 9.97 \\
\hline 10.54 & 10.21 & 8.64 & 9.45 & 5.00 & 10.32 & 10.43 & 9.81 & 9.82 & 9.23 & 9.71 \\
\hline 2.84 & 2.72 & 3.22 & 3.22 & 1.24 & 2.80 & 2.71 & 2.78 & 2.94 & 2.25 & 2.37 \\
\hline 0.29 & 0.23 & 0.89 & 0.47 & 0.21 & 0.16 & 0.46 & 0.92 & 0.39 & 0.11 & 0.20 \\
\hline 0.44 & 1.34 & 1.30 & 1.79 & 4.59 & 0.74 & 0.47 & 0.83 & 1.32 & 2.60 & 1.64 \\
\hline 0.54 & 2.58 & 2.75 & 1.39 & 1.40 & 1.50 & 2.03 & 1.42 & 0.56 & 2.51 & 2.69 \\
\hline 2.48 & 2.00 & 2.59 & 2.79 & 1.23 & 2.46 & 2.57 & 2.89 & 2.66 & 1.88 & 2.24 \\
\hline 0.25 & 0.19 & 0.29 & 0.31 & 0.11 & 0.26 & 0.31 & 0.34 & 0.27 & 0.16 & 0.27 \\
\hline 0.19 & 0.12 & 0.11 & 0.15 & 0.16 & 0.17 & 0.17 & 0.17 & 0.17 & 0.19 & 0.19 \\
\hline 0.06 & 0.02 & 0.12 & 0.02 & 0.05 & 0.04 & 0.08 & 0.10 & 0.04 & 0.06 & 0.40 \\
\hline 100.10 & 100.48 & 100.75 & 100.71 & 99.62 & 99.99 & 99.87 & 99.59 & 100.51 & 100.26 & 100.74 \\
\hline \multicolumn{11}{|c|}{ Dry Reduced Normalized } \\
\hline 49.45 & 49.24 & 48.63 & 47.73 & 46.44 & 49.33 & 49.71 & 49.16 & 47.15 & 47.98 & 48.86 \\
\hline 14.14 & 15.41 & 16.09 & 15.97 & 9.65 & 14.58 & 14.11 & 14.43 & 15.13 & 14.25 & 13.31 \\
\hline 13.10 & 11.42 & 11.55 & 12.42 & 12.64 & 12.40 & 12.00 & 12.26 & 12.74 & 12.01 & 11.70 \\
\hline 6.52 & 7.84 & 7.34 & 6.99 & 22.75 & 7.08 & 7.00 & 6.65 & 8.44 & 11.11 & 10.44 \\
\hline 10.67 & 10.62 & 9.00 & 9.74 & 5.36 & 10.60 & 10.76 & 10.16 & 10.00 & 9.78 & 10.17 \\
\hline 2.88 & 2.83 & 3.35 & 3.32 & 1.33 & 2.88 & 2.79 & 2.88 & 2.99 & 2.39 & 2.48 \\
\hline 0.29 & 0.24 & 0.93 & 0.48 & 0.23 & 0.16 & 0.47 & 0.95 & 0.40 & 0.12 & 0.21 \\
\hline 2.51 & 2.08 & 2.70 & 2.88 & 1.32 & 2.53 & 2.65 & 2.99 & 2.71 & 1.99 & 2.35 \\
\hline 0.25 & 0.20 & 0.30 & 0.32 & 0.12 & 0.27 & 0.32 & 0.35 & 0.27 & 0.17 & 0.28 \\
\hline 0.19 & 0.12 & 0.11 & 0.15 & 0.17 & 0.17 & 0.18 & 0.18 & 0.17 & 0.20 & 0.20 \\
\hline \multicolumn{11}{|c|}{ Norms $\left(\mathrm{Fe}^{+3} /\left[\mathrm{Fe}^{+3}+\mathrm{Fe}^{+2}\right]\right)=0.15$} \\
\hline 1.71 & 1.42 & 5.48 & 2.83 & 1.36 & 0.94 & 2.78 & 5.63 & 2.36 & 0.71 & 1.24 \\
\hline 24.32 & 23.90 & 28.29 & 28.03 & 11.23 & 24.32 & 23.73 & 24.42 & 25.25 & 20.18 & 21.06 \\
\hline 24.74 & 28.58 & 26.07 & 27.20 & 19.64 & 26.33 & 24.58 & 23.69 & 26.62 & 27.74 & 24.68 \\
\hline- & - & - & - & - & - & - & - & - & - & - \\
\hline 21.82 & 18.54 & 13.50 & 15.52 & 4.88 & 20.02 & 21.92 & 20.10 & 17.24 & 15.86 & 19.46 \\
\hline 11.04 & 9.48 & 6.90 & 7.91 & 2.55 & 10.18 & 11.18 & 10.24 & 8.82 & 8.17 & 10.05 \\
\hline 5.62 & 5.43 & 3.96 & 4.33 & 1.81 & 5.52 & 6.25 & 5.66 & 5.06 & 5.08 & 6.37 \\
\hline 5.15 & 3.63 & 2.64 & 3.29 & 0.52 & 4.31 & 4.49 & 4.19 & 3.36 & 2.60 & 3.04 \\
\hline 15.24 & 12.21 & 2.55 & 1.66 & 23.64 & 15.79 & 15.98 & 10.77 & 1.38 & 13.61 & 16.95 \\
\hline 7.96 & 7.38 & 1.53 & 0.94 & 18.40 & 8.86 & 9.30 & 6.19 & 0.83 & 9.00 & 11.47 \\
\hline 7.28 & 4.89 & 1.02 & 0.78 & 5.23 & 6.93 & 6.68 & 4.58 & 0.55 & 4.61 & 5.48 \\
\hline 1.84 & 4.72 & 8.94 & 8.48 & 25.45 & 2.25 & 1.34 & 3.32 & 10.57 & 9.49 & 5.76 \\
\hline 1.85 & 3.48 & 6.57 & 7.09 & 7.98 & 1.94 & 1.06 & 2.71 & 7.75 & 5.36 & 3.03 \\
\hline 3.15 & 2.75 & 2.80 & 3.00 & 3.05 & 3.00 & 2.82 & 2.86 & 3.07 & 2.89 & 2.71 \\
\hline 4.76 & 3.94 & 5.12 & 5.46 & 2.50 & 4.80 & 5.04 & 5.69 & 5.14 & 3.77 & 4.46 \\
\hline 0.59 & 0.47 & 0.71 & 0.76 & 0.28 & 0.64 & 0.76 & 0.83 & 0.64 & 0.40 & 0.67 \\
\hline 100.02 & 100.01 & 100.02 & 100.02 & 100.01 & 100.02 & 100.02 & 100.02 & 100.02 & 100.01 & 100.02 \\
\hline
\end{tabular}

Because of their abundance and simple phenocryst mineralogy, we have chosen to use olivine + chromite phyric tholeiitic basalts to make this comparison. This is because it is possible to normalize analyses of this rock type to a constant $\mathrm{Mg} /(\mathrm{Mg}+\mathrm{Fe})$ value by olivine fractionation only. This, then, allows comparison of lavas from different volcanoes at the same stage of fractionation, assuming that olivine has been the only significant fractionating phase since the magma was formed and that olivine is always left as a residual phase after partial melting. If mineralogical descriptions are not given in the original references, we have used only analyses with $\mathrm{MgO}$ content greater than 8 per cent. These, in our experience, have almost always only olivine + chromite phenocrysts.

The normalizations were carried out by averaging the selected dry reduced analyses for each volcano and adding or subtracting olivine with the composition $\mathrm{Fo}_{86}$ to give $\mathrm{Mg} /\left(\mathrm{Mg}+0.85 \mathrm{Fe}_{\mathrm{T}}\right)=0.70$. These calculated magma compositions should be in equilibrium with mantle olivine if $K_{M g}=0.3$ (Roeder and Emslie, 1970).
$\mathrm{Fe}^{+2}=0.85 \mathrm{Fe}_{\mathrm{T}}$ gives roughly the $\mathrm{Fe}^{+2} / \mathrm{Fe}^{+3}$ ratio of the least oxidized tholeiitic basalts of Kilauea and Mauna Loa (Wright, 1971). $\mathrm{Fo}_{86}$ is a good average for the olivine phenocryst compositions in this rock type. We do not propose that the normalized average compositions represent original parental magmas, although they could be fairly close. Our objective is only to compare rocks from different volcanoes under conditions as similar as possible.

Table 11 presents the averaged and normalized dry reduced compositions for each volcano for which data are available. Table 12 presents the averaged as received analyses for the various rock types from the Leg 55 drill sites.

The principal conclusion to be drawn from Table 11 is that there appear to be no systematic changes in any of the major elements for olivine tholeiites along the chain from Kilauea to Suiko. There are large differences in many of the elements from volcano to volcano $\left(\mathrm{TiO}_{2}\right.$ for Kilauea and Mauna Loa) and even for different types at the same volcano (high- $\mathrm{TiO}_{2}$ and low- 
TABLE 8 - Continued

\begin{tabular}{|c|c|c|c|c|c|c|c|c|c|}
\hline \multirow{2}{*}{$\begin{array}{l}\text { Hole } \\
\text { Core-Sec., } \\
\text { Interval (cm) } \\
\text { Flow Unit }\end{array}$} & \multicolumn{7}{|c|}{$433 \mathrm{C}$} & \multirow[b]{2}{*}{$\begin{array}{c}47-5,92-100 \\
64\end{array}$} & \multirow[b]{2}{*}{$\begin{array}{c}49-2,17-24 \\
66\end{array}$} \\
\hline & $\begin{array}{c}37-3,79-87 \\
44\end{array}$ & $\begin{array}{c}38-1,67-76 \\
45 B\end{array}$ & $\begin{array}{c}39-5,87-94 \\
48\end{array}$ & $\begin{array}{c}40-2,88-96 \\
49\end{array}$ & $\begin{array}{c}42-1,56-63 \\
52\end{array}$ & $\begin{array}{c}42-3,11-20 \\
53\end{array}$ & $\begin{array}{c}42-5,85-92 \\
54\end{array}$ & & \\
\hline \multicolumn{10}{|c|}{ As Received } \\
\hline $\mathrm{SiO}_{2}$ & 47.57 & 44.80 & 47.28 & 47.32 & 47.75 & 47.39 & 47.91 & 44.10 & 45.34 \\
\hline $\mathrm{Al}_{2} \mathrm{O}_{3}$ & 13.81 & 13.25 & 12.82 & 12.61 & 13.25 & 15.97 & 14.76 & 14.51 & 15.41 \\
\hline $\mathrm{Fe}_{2} \mathrm{O}_{3}$ & 3.63 & 3.67 & 2.51 & 3.90 & 4.78 & 4.58 & 4.20 & 11.01 & 9.22 \\
\hline $\mathrm{FeO}$ & 7.72 & 8.69 & 9.17 & 7.90 & 7.41 & 5.62 & 6.92 & 3.37 & 4.16 \\
\hline $\mathrm{MgO}$ & 8.49 & 11.79 & 10.62 & 10.73 & 7.57 & 7.22 & 7.04 & 5.09 & 5.73 \\
\hline $\mathrm{CaO}$ & 10.28 & 7.95 & 9.50 & 9.68 & 9.77 & 10.04 & 11.24 & 9.23 & 9.14 \\
\hline $\mathrm{Na}_{2} \mathrm{O}$ & 2.48 & 2.36 & 2.15 & 2.36 & 2.50 & 2.84 & 2.46 & 3.08 & 3.08 \\
\hline $\mathrm{K}_{2} \mathrm{O}$ & 0.16 & 0.45 & 0.21 & 0.21 & 0.31 & 0.23 & 0.16 & 1.51 & 0.54 \\
\hline $\mathrm{H}_{2} \mathrm{O}^{+}$ & 1.33 & 3.30 & 1.75 & 1.73 & 0.76 & 1.35 & 0.47 & 1.78 & 1.87 \\
\hline $\mathrm{H}_{2} \mathrm{O}^{-}$ & 2.27 & 1.46 & 1.10 & 1.00 & 2.84 & 3.45 & 2.24 & 2.25 & 3.19 \\
\hline $\mathrm{TiO}_{2}$ & 2.00 & 2.11 & 2.15 & 2.14 & 2.40 & 1.77 & 1.92 & 3.02 & 2.76 \\
\hline $\mathrm{P}_{2} \mathrm{O}_{5}$ & 0.19 & 0.20 & 0.23 & 0.25 & 0.22 & 0.15 & 0.18 & 0.32 & 0.30 \\
\hline $\mathrm{MnO}$ & 0.17 & 0.16 & 0.17 & 0.17 & 0.13 & 0.12 & 0.13 & 0.16 & 0.16 \\
\hline $\mathrm{CO}_{2}$ & 0.03 & 0.04 & 0.05 & 0.07 & 0.10 & 0.04 & 0.09 & 0.51 & 0.09 \\
\hline Total & 100.14 & 100.23 & 99.71 & 100.07 & 99.79 & 100.77 & 99.72 & 99.94 & 100.99 \\
\hline \multicolumn{10}{|c|}{ Dry Reduced Normalized } \\
\hline $\mathrm{SiO}_{2}$ & 49.48 & 47.13 & 48.96 & 48.84 & 49.94 & 49.64 & 49.65 & 46.77 & 47.77 \\
\hline $\mathrm{Al}_{2} \mathrm{O}_{3}$ & 14.36 & 13.94 & 13.28 & 13.02 & 13.86 & 16.73 & 15.30 & 15.39 & 16.24 \\
\hline $\mathrm{FeO}$ & 11.43 & 12.62 & 11.85 & 11.78 & 12.26 & 10.20 & 11.09 & 14.08 & 13.13 \\
\hline $\mathrm{MgO}$ & 8.83 & 12.40 & 11.00 & 11.08 & 7.92 & 7.56 & 7.30 & 5.40 & 6.04 \\
\hline $\mathrm{CaO}$ & 10.69 & 8.36 & 9.84 & 9.99 & 10.22 & 10.52 & 11.65 & 9.79 & 9.63 \\
\hline $\mathrm{Na}_{2} \mathrm{O}$ & 2.58 & 2.48 & 2.23 & 2.44 & 2.61 & 2.97 & 2.55 & 3.27 & 3.24 \\
\hline $\mathrm{K}_{2} \mathrm{O}$ & 0.17 & 0.47 & 0.22 & 0.22 & 0.32 & 0.24 & 0.17 & 1.60 & 0.57 \\
\hline $\mathrm{TiO}_{2}$ & 2.08 & 2.22 & 2.23 & 2.21 & 2.51 & 1.85 & 1.99 & 3.20 & 2.91 \\
\hline $\mathrm{P}_{2} \mathrm{O}_{5}$ & 0.20 & 0.21 & 0.24 & 0.26 & 0.23 & 0.16 & 0.19 & 0.34 & 0.32 \\
\hline $\mathrm{MnO}$ & 0.18 & 0.17 & 0.18 & 0.18 & 0.14 & 0.13 & 0.13 & 0.17 & 0.17 \\
\hline \multicolumn{10}{|c|}{$\operatorname{Norms}\left(\mathrm{Fe}^{+3} /\left[\mathrm{Fe}^{+3}+\mathrm{Fe}^{+2}\right]\right)=0.15$} \\
\hline OR & 1.00 & 2.77 & 1.30 & 1.30 & 1.90 & 1.42 & 1.01 & 9.43 & 3.36 \\
\hline $\mathrm{AB}$ & 21.79 & 20.94 & 21.95 & 20.68 & 22.16 & 25.09 & 21.62 & 20.45 & 27.35 \\
\hline AN & 27.04 & 25.46 & 23.86 & 23.96 & 25.24 & 31.56 & 29.86 & 22.53 & 28.02 \\
\hline $\mathrm{NE}$ & - & - & - & - & - & - & - & 3.87 & - \\
\hline DI & 20.00 & 11.77 & 18.81 & 19.38 & 19.68 & 15.89 & 21.89 & 19.68 & 14.50 \\
\hline DIWO & 10.26 & 6.08 & 9.72 & 10.01 & 10.07 & 8.14 & 11.19 & 9.90 & 7.33 \\
\hline DIEN & 6.09 & 3.86 & 6.17 & 6.38 & 5.83 & 4.78 & 6.41 & 4.62 & 3.69 \\
\hline DIFS & 3.65 & 1.83 & 2.92 & 2.99 & 3.78 & 2.97 & 4.30 & 5.17 & 3.48 \\
\hline HY & 16.70 & 9.35 & 14.30 & 16.36 & 22.44 & 11.62 & 16.35 & - & 4.44 \\
\hline HYEN & 10.44 & 6.35 & 9.70 & 11.14 & 13.61 & 7.17 & 9.79 & - & 2.28 \\
\hline HYFS & 6.26 & 3.01 & 4.60 & 5.22 & 8.83 & 4.46 & 6.56 & - & 2.16 \\
\hline $\mathrm{FO}$ & 3.79 & 14.44 & 8.04 & 7.09 & 0.25 & 4.80 & 1.41 & 6.17 & 6.33 \\
\hline $\mathrm{FA}$ & 2.50 & 7.53 & 4.20 & 3.66 & 0.18 & 3.29 & 1.04 & 7.62 & 6.58 \\
\hline MT & 2.76 & 3.04 & 2.77 & 2.76 & 2.84 & 2.46 & 2.59 & 3.40 & 3.17 \\
\hline IL & 3.94 & 4.21 & 4.22 & 4.20 & 4.78 & 3.51 & 3.79 & 6.06 & 5.51 \\
\hline $\mathrm{AP}$ & 0.47 & 0.50 & 0.57 & 0.62 & 0.55 & 0.38 & 0.45 & 0.80 & 0.76 \\
\hline Total & 100.01 & 100.01 & 100.02 & 100.02 & 100.01 & 100.01 & 100.01 & 100.02 & 100.02 \\
\hline
\end{tabular}

Notes: 1 - Cl analyses on 433A-21-4, 129-138 cm; 433C-13-2, 55-66 cm; 433C-14-3, 8-15 cm; 433C-15-6, 16-31 cm; 433-17-1, 78-82 cm; 433C-28-2,

$73-80 \mathrm{~cm} ; 433 \mathrm{C}-47-5,92-100 \mathrm{~cm}$; and $433 \mathrm{C}-49-2,17-24 \mathrm{~cm}$ gave $<0.05 \%$.

$\mathrm{TiO}_{2}$ types at Suiko), but there are no uniform changes along the chain. The only possible systematic difference is that the lavas from Nihoa (7 m.y.B.P.) to Daikakuji (45 m.y.B.P.) may have lower $\mathrm{Al}_{2} \mathrm{O}_{3}$ and higher $\mathrm{TiO}_{2}$ contents than those before (Suiko) and after (Niihau to Kilauea).

This lack of variation in major-element compositions is in good agreement with the lack of systematic variation in incompatible trace element ratios found by Clague and Frey (this volume). Subtle variations like the decrease in initial strontium isotope ratios from the Hawaii-Emperor bend to Suiko found by Lanphere et al. (this volume) are probably beyond the resolution of our averaging and normalizing procedure.

\section{SPECULATION ON THE ORIGIN OF THE HAWAIIAN-EMPEROR MAGMA}

The lack of systematic variation in the major and trace elements along the chain, discussed above and by Clague and Frey (this volume), implies that the conditions of magma genesis, the composition of the parental material, and the extent of melting at the Hawaiian hot spot have not changed significantly since Suiko was formed. There have clearly been fluctuations in at least one of these, but mostly they appear to be relatively short-lived. Kilauea and Mauna Loa lavas, for instance, are significantly different, but both volcanoes are presently active. The $\mathrm{CaO}$ and $\mathrm{TiO}_{2}$ anomalies for Nihoa to Daikakuji may represent a longer term fluctuation in source composition. The major problem, however, is how to account for the overall stability.

If the Hawaiian hot spot is to be relatively fixed (and the magnetic evidence from Suiko [Kono, this volume] indicates that at least the change in latitude has not been great), the heat source for the igneous activity must be at least as deep as the asthenosphere and possibly deeper. It is very unlikely that it is in the lithosphere, since the lithosphere in the Pacific appears to be in motion away from the east Pacific rise.

The evidence for the ultimate location of the magma's source material is considerably weaker. The lines of evidence we have are that (1) the depth of melting to produce the parental tholeiitic magma must 


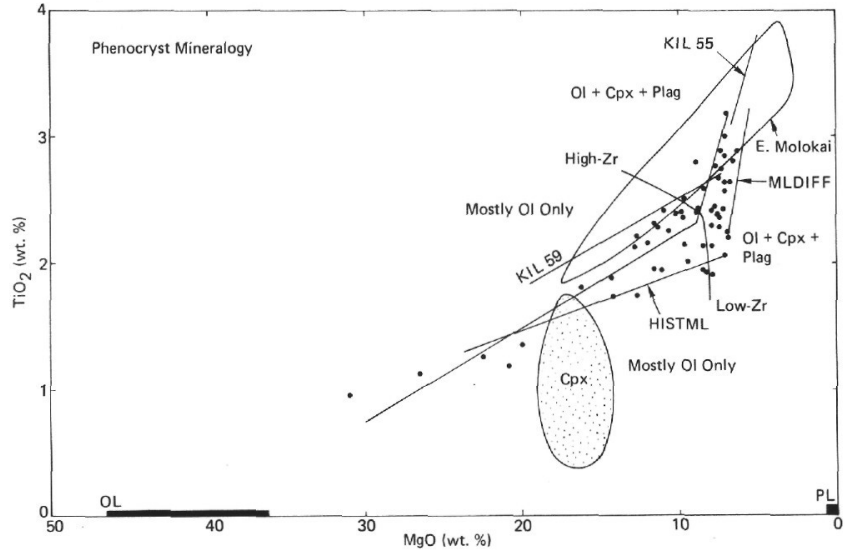

Figure 18. Phenocryst phases present in Site 433 tholeiitic basalts versus position in $\mathrm{TiO}_{2}-\mathrm{MgO}$ for both high-Zr and low-Zr types.

TABLE 9

Trace-Element Analyses of Lava Flows from Suiko Seamount, DSDP Site 433

\begin{tabular}{|c|c|c|c|c|c|c|c|c|c|}
\hline \multirow[b]{2}{*}{ Hole } & \multirow[b]{2}{*}{$\begin{array}{l}\text { Core-Section, } \\
\text { Interval }(\mathrm{cm})\end{array}$} & \multirow[b]{2}{*}{$\begin{array}{l}\text { Flow } \\
\text { Unit }\end{array}$} & \multicolumn{7}{|c|}{ Concentrations (ppm) } \\
\hline & & & $\mathrm{Ba}$ & $\mathrm{Cr}$ & $\mathrm{Ni}$ & $\mathrm{Sr}$ & $\mathrm{Zn}$ & $\mathrm{Zr}$ & $\mathrm{Y}$ \\
\hline $\begin{array}{l}433 \mathrm{~A} \\
433 \mathrm{~A}\end{array}$ & $\begin{array}{l}20-1,30-36 \\
21-4,129-138\end{array}$ & $\begin{array}{l}1 \\
1\end{array}$ & $\begin{array}{l}295 \\
270\end{array}$ & $\begin{array}{l}<100 \\
<100\end{array}$ & $\begin{array}{l}41 \\
40\end{array}$ & $\begin{array}{l}390 \\
380\end{array}$ & $\begin{array}{l}143 \\
135\end{array}$ & $\begin{array}{l}200 \\
210\end{array}$ & $\begin{array}{l}44 \\
37\end{array}$ \\
\hline $433 B$ & $5-3,89-92$ & 1 & 250 & $<100$ & 95 & 360 & 112 & 188 & 28 \\
\hline $433 \mathrm{C}$ & $4-1,25-28$ & 2 & 245 & $<100$ & 126 & 345 & 125 & 188 & 30 \\
\hline $433 \mathrm{C}$ & $6-2,76-79$ & 3 & 305 & $<100$ & 36 & 360 & 152 & 230 & 3 \\
\hline $433 \mathrm{C}$ & $10-4,11-17$ & $4 \mathrm{~F}$ & 174 & $<100$ & 275 & 200 & 121 & 129 & 27 \\
\hline $433 \mathrm{C}$ & $12-3,57-65$ & 9 & 107 & $<100$ & 127 & 305 & 128 & 143 & 27 \\
\hline $433 C$ & $13-2,55-66$ & 10 & 144 & 224 & 89 & 245 & 85 & 140 & 12 \\
\hline $433 C$ & $14-3,8-15$ & $11 \mathrm{~B}$ & 87 & 116 & 43 & 285 & 116 & 162 & 32 \\
\hline $433 \mathrm{C}$ & $15-6,16-31$ & 13 & 95 & 110 & 56 & 290 & 117 & 163 & 25 \\
\hline $433 \mathrm{C}$ & $19-5,57-65$ & $15 \mathrm{~A}$ & 178 & 250 & 101 & 275 & 101 & 127 & 27 \\
\hline $433 \mathrm{C}$ & $21-4,7-13$ & 17 & 163 & 172 & 106 & 340 & 150 & 173 & 30 \\
\hline $433 C$ & $22-5,45-52$ & 18 & 156 & 186 & 99 & 350 & 117 & 173 & 35 \\
\hline $433 \mathrm{C}$ & $24-7,133-139$ & 19D & 70 & 390 & 860 & 87 & 128 & 79 & 21 \\
\hline $433 \mathrm{C}$ & $29-1,112-123$ & $26 \mathrm{~A}$ & 101 & $<100$ & 70 & 300 & 113 & 169 & 33 \\
\hline $433 \mathrm{C}$ & $29-2,94-100$ & $26 B$ & 98 & $<100$ & 61 & 305 & 128 & 194 & 33 \\
\hline $433 \mathrm{C}$ & $34-2,103-111$ & 33 & 79 & 470 & 350 & 240 & 99 & 121 & 23 \\
\hline $433 \mathrm{C}$ & $34-7,114-121$ & 35 & 98 & 385 & 260 & 280 & 114 & 151 & 31 \\
\hline $433 C$ & $37-3,79-87$ & 44 & 66 & 310 & 142 & 96 & $<5$ & 111 & $<9$ \\
\hline $433 \mathrm{C}$ & $38-1,67-76$ & $45 \mathrm{~B}$ & 94 & 440 & 385 & 260 & 119 & 133 & 28 \\
\hline $433 C$ & $39-5,87-94$ & 48 & 99 & 410 & 270 & 150 & 114 & 131 & 24 \\
\hline $433 C$ & $40-2,88-96$ & 49 & 98 & 410 & 310 & 235 & 111 & 137 & 34 \\
\hline $433 C$ & $42-1,56-63$ & 52 & 85 & 235 & 82 & 260 & 112 & 156 & 46 \\
\hline $433 \mathrm{C}$ & $42-3,11-20$ & 53 & 63 & 255 & 81 & 265 & 87 & 101 & 31 \\
\hline $433 \mathrm{C}$ & $42-5,85-92$ & 54 & 64 & 255 & 76 & 250 & 70 & 129 & 21 \\
\hline $433 \mathrm{C}$ & $47-5,92-100$ & 64 & 118 & 270 & 127 & 270 & 113 & 183 & 41 \\
\hline $433 C$ & $49-2,17-24$ & 66 & 215 & 113 & 111 & 320 & 123 & 175 & 33 \\
\hline
\end{tabular}

be relatively constant and probably fairly shallow, or there would not be tholeiitic basalts (Green and Ringwood, 1967); (2) the source material must be fairly uniform through time and must be continually replenished, or the magma composition would change and igneous activity would eventually stop; and (3) on the basis of seismic activity progressing to volcanism, the magma apparently enters conduits at a depth of at least $60 \mathrm{~km}$ (Wright, 1971). Because this depth is in the lithosphere, the source region could be in the lower lithosphere or asthenosphere. We do not have criteria to unambiguously distinguish these possibilities.

There are at least two physical pictures which are consistent with the data and with a heat source in the asthenosphere. The first is that material from the as- thenosphere rises into the lower lithosphere where the melt separates from the residual crystals and rises to form the volcanoes. The other physical picture is that there is a more or less fixed and continuously operating heat source in the asthenosphere (diapirs or a plume, perhaps) which heats and partially melts the lower lithosphere as it passes over. The melt then separates from the residual crystals, enters a conduit system, and finally erupts to form the volcanoes.

In either of these pictures minor differences in magma compositon between volcanoes or even at one volcano can be accounted for by small variations in the source compositon, volatile content, fraction of melting, or depth of separation from the residual crystals.

Other physical pictures are also possible, and we do not mean to exclude them. Any other models must, however, be able to account for the data presented in this volume.

\section{ACKNOWLEDGMENTS}

The analyses reported here were done by N. H. Elsheimer, L. F. Espos, and S. T. Neil of the U. S. Geological Survey, Menlo Park. Their efforts are greatly appreciated. We also wish to thank Brent Dalrymple for many useful discussions and his help in preparing this paper. Most of all we wish to thank Dale Jackson, without whom this paper and this volume would not have been possible. Would that he were here.

\section{REFERENCES}

Bargar, K. E. and Jackson, E. D., 1974. Calculated volumes of individual shield volcanoes along the Hawaiian-Emperor chain, Jour. Research U. S. Geol. Survey, v. 2, pp. 545550.

Beeson, M. H., 1976. Petrology, Mineralogy, and Geochemistry of the East Molokai Volcanic Series, Hawaii, $U . S$. Geol. Surv. Prof. Paper 961, U. S. Government Printing Office, Washington, $53 \mathrm{pp}$.

Bonhommet, N., Beeson, M. H., and Dalrymple, G. B., 1977. A contribution to the Geochronology and Petrology of the Island of Lanai, Hawaii, Geol. Soc. Am. Bull., v. 88, pp. 1282-1286.

Dalrymple, G. B., Lanphere, M. A., and Jackson, E. D., 1974. Contributions to the petrography and geochronology of volcanic rocks from the Leeward Hawaiian Islands, Geol. Soc. Am. Bull., v. 85, pp. 727-738.

Green, D. H., and Ringwood, A. E., 1967. The genesis of basaltic magmas, Contr. Min. Pet., v. 15, pp. 103-190.

Macdonald, G. A., 1968. Composition and origin of Hawaiian lava, Geol. Soc. Am. Mem., v. 116, pp. 477-522.

Macdonald, G. A., and Katsura, T., 1964. Chemical composition of Hawaiian lavas, J. Petrol., v. 5, pp. 82-133.

Muir, I. D. and Tilley, C. E., 1961. Mugearites and their place in alkali igneous rock series, J. Geol., v. 69, pp. 186-203.

Roeder, P. L. and Emslie, R. F., 1970. Olivine-liquid equilibrium, Contr. Min. Pet., v. 29, pp. 275-289.

Wright, T. L., 1971. Chemistry of Kilauea and Mauna Loa lavas in time and space, U. S. Geol. Survey Prof. Paper 735, $40 \mathrm{pp}$.

Wright, T. L., and Doherty, P. C., 1970. A linear programming and least squares computer method of solving petrologic mixing problems, Geol. Soc. Am. Bull., v. 81, pp. 1995-2008.

Wright, T. L., and Fiske, R. S., 1971. Origin of the differentiated and hybrid lavas of Kilauea volcano, Hawaii, $J$. Petrol., v. 12, pp. 1-65. 
TABLE 10

Stratigraphy of Tholeiitic Basalts, Hole 433C

\begin{tabular}{|c|c|c|c|c|c|c|c|}
\hline $\begin{array}{l}\text { Strat. } \\
\text { Group }\end{array}$ & $\begin{array}{l}\text { Chemical } \\
\text { Type }\end{array}$ & Flow Units & $\begin{array}{c}\text { Range } \\
\text { (Core-Sec., } \\
\text { Interval }[\mathrm{cm}])\end{array}$ & Depth $(\mathrm{m})$ & Phenocrysts & $\begin{array}{l}\text { Magnetica } \\
\text { Unit }\end{array}$ & Comments \\
\hline A & Low $\mathrm{Zr}$ & $\begin{array}{l}4 \mathrm{a}, 4 \mathrm{~b}, 4 \mathrm{c} \\
4 \mathrm{~d}, 4 \mathrm{e}\end{array}$ & $\begin{array}{l}10 \text { (top)- } \\
10-3,150\end{array}$ & $\begin{array}{l}203- \\
208\end{array}$ & Ol & 2 & $\begin{array}{l}\text { Groups } A \text { and } C \text { may be the same unit } \\
\text { separated by a stray flow from another } \\
\text { source. }\end{array}$ \\
\hline B & $\mathrm{Hi} \mathrm{Zr}$ & $4 \mathrm{f}$ & $\begin{array}{l}10-4,0- \\
10-4,65\end{array}$ & $\begin{array}{l}208- \\
211\end{array}$ & $\mathrm{Ol}$ & 2 & \\
\hline $\mathrm{C}$ & Low Zr & $\begin{array}{l}4 \mathrm{~g}, 4 \mathrm{~h} \\
5,6,7\end{array}$ & $\begin{array}{l}10-4,65- \\
11-4,15\end{array}$ & $\begin{array}{l}211- \\
218.5\end{array}$ & $\mathrm{O} 1$ & 2 & \\
\hline $\mathrm{D}$ & Low $\mathrm{Zr}$ & $8,9,10$ & $\begin{array}{l}11-4,15- \\
13-3,60\end{array}$ & $\begin{array}{l}218.5- \\
233\end{array}$ & $\mathrm{Ol}, \mathrm{Pl}, \mathrm{Cpx}$ & $3,4 / 5$ & \\
\hline $\mathrm{E}$ & Low $\mathrm{Zr}$ & $\begin{array}{l}11 b, 11 c \\
12,13\end{array}$ & $\begin{array}{l}14-1,0- \\
19-1,55\end{array}$ & $\begin{array}{l}242.5- \\
262\end{array}$ & $\mathrm{Ol}, \mathrm{Pl}, \mathrm{Cpx}$ & $\overline{6 / 7}$ & $11 \mathrm{a}$ and $11 \mathrm{~d}$ not analyzed. \\
\hline $\mathrm{F}$ & Low $\mathrm{Zr}$ & 14 & $\begin{array}{l}19-1,55- \\
19-1,145\end{array}$ & $\begin{array}{l}262- \\
264.5\end{array}$ & $\mathrm{Ol}, \mathrm{Pl}, \mathrm{Cpx}$ & 8 & \\
\hline G & Low $\mathrm{Zr}$ & $15 \mathrm{a}$ & $\begin{array}{l}19-2,145- \\
20-1,60\end{array}$ & $\begin{array}{l}264.5- \\
272\end{array}$ & $\mathrm{Ol}, \mathrm{Pl}, \mathrm{Cpx}$ & $\overline{9}$ & $15 \mathrm{~b}$ not analyzed. \\
\hline $\mathbf{H}$ & Low $\mathrm{Zr}$ & $16,17,18$ & $\begin{array}{l}20-2,80- \\
22-6,15\end{array}$ & $\begin{array}{l}272- \\
297.5\end{array}$ & $\mathrm{Ol}, \mathrm{Pl}, \mathrm{Cpx}$ & $10 / \overline{11}$ & \\
\hline I & $\mathrm{Hi} \mathrm{Zr}$ & $19 \mathrm{a}$ & $\begin{array}{l}23-1,0- \\
23-1,120\end{array}$ & $\begin{array}{l}297.5- \\
299\end{array}$ & $\mathrm{Ol}, \mathrm{Cpx}$ & 12 & $19 \mathrm{~b}$ not analyzed. \\
\hline $\mathrm{J}$ & Low $\mathrm{Zr}$ & $19 \mathrm{c}, 19 \mathrm{~d}$ & $\begin{array}{l}23-4,40- \\
25-1,65\end{array}$ & $\begin{array}{l}303- \\
317.5\end{array}$ & $\mathrm{Ol}$ & 12 & \\
\hline $\mathrm{K}$ & Low $\mathrm{Zr}$ & 20,21 & $\begin{array}{l}25-1,65- \\
26-3,95\end{array}$ & $\begin{array}{l}317.5- \\
330.5\end{array}$ & $\mathrm{Ol}(\mathrm{Pl}$-trace $)$ & 12,13 & . \\
\hline $\mathrm{L}$ & $\mathrm{Hi} \mathrm{Zr}$ & 22,23 & $\begin{array}{l}26-3,95- \\
26-7,20\end{array}$ & $\begin{array}{l}330.5- \\
336\end{array}$ & $\mathrm{OI}$ & 14 & $\begin{array}{l}\text { Groups } L \text { and } M \text { may be same unit, } M \\
\text { more } 01 \text {-rich. }\end{array}$ \\
\hline M & $\mathrm{Hi} \mathrm{Zr}$ & $24 \mathrm{a}$ & $\begin{array}{l}26-7,20- \\
27-3,75\end{array}$ & $\begin{array}{l}336- \\
340\end{array}$ & $\mathrm{Ol}$ & 15 & $24 b$ not analyzed. \\
\hline $\mathrm{N}$ & Low $\mathrm{Zr}$ & $25,26 \mathrm{a}, 26 \mathrm{~b}$ & $\begin{array}{l}27-6,35- \\
29-3,75\end{array}$ & $\begin{array}{l}344- \\
359\end{array}$ & $\mathrm{Ol}, \mathrm{Pl}, \mathrm{Cpx}$ & $16 / 17$ & \\
\hline $\mathrm{O}$ & $\mathrm{Hi} \mathrm{Zr}$ & 27 & $\begin{array}{l}29-3,75- \\
31-2,55\end{array}$ & $\begin{array}{l}359- \\
376\end{array}$ & $\mathrm{Ol}, \mathrm{Pl}, \mathrm{Cpx}$ & $\overline{18}$ & \\
\hline $\mathrm{P}$ & $\mathrm{Hi} \mathrm{Zr}$ & $28 \mathrm{c}, 29$ & $\begin{array}{l}31-2,55- \\
32-5,130\end{array}$ & $\begin{array}{l}376- \\
391\end{array}$ & $\mathrm{Ol}$ & $19 \overline{-} 20$ & $28 \mathrm{a}, \mathrm{b}, \mathrm{d}, 30,31,32$ not analyzed. \\
\hline Q & $\mathrm{Hi} \mathrm{Zr}$ & 33 & $\begin{array}{l}34-1,110- \\
34-3,120\end{array}$ & $\begin{array}{l}403.5- \\
406.5\end{array}$ & $\mathrm{Ol}$ & 22 & 34 not analyzed. \\
\hline $\mathrm{R}$ & $\mathrm{Hi} \mathrm{Zr}$ & $\begin{array}{l}35,37 \\
38,39,41\end{array}$ & $\begin{array}{l}34-6,50- \\
36-5,145\end{array}$ & $\begin{array}{l}411.5- \\
429\end{array}$ & $\begin{array}{l}\mathrm{Ol} \\
\text { (F.U. } 35-\mathrm{Ol}, \\
\mathrm{Pl}, \mathrm{Cpx})\end{array}$ & $23,24,25$ & $36,40,42,43$ not analyzed. \\
\hline S & Low $\mathrm{Zr}$ & 44 & $\begin{array}{l}37-2,0- \\
37-4,115\end{array}$ & $\begin{array}{l}432- \\
436.5\end{array}$ & $\mathrm{Ol}$ & 26 & \\
\hline $\mathrm{T}$ & $\mathrm{Hi} \mathrm{Zr}$ & 45 & $\begin{array}{l}37-4,115- \\
38-2,50\end{array}$ & $\begin{array}{l}436.5- \\
442.5\end{array}$ & $\mathrm{Ol}$ & 27 & 46 not analyzed. \\
\hline $\mathrm{U}$ & Low $\mathrm{Zr}$ & 47 & $\begin{array}{l}38-4,10- \\
39-1,115\end{array}$ & $\begin{array}{l}445- \\
451.5\end{array}$ & aphyric & 28 & \\
\hline $\mathrm{V}$ & $\mathrm{Hi} \mathrm{Zr}$ & 48,49 & $\begin{array}{l}39-1,115- \\
40-3,90\end{array}$ & $\begin{array}{l}451.5- \\
463.5\end{array}$ & $\begin{array}{c}\mathrm{Ol} \\
(48-\text { trace } \mathrm{Pl})\end{array}$ & $\overline{29}$ & 50 not analyzed. \\
\hline W & Low $\mathrm{Zr}$ & $\begin{array}{l}51 \mathrm{~b}, 52 \\
53,54,60 \\
62 \mathrm{a}\end{array}$ & $\begin{array}{l}40-5,113- \\
46-3,140\end{array}$ & $\begin{array}{l}467- \\
521\end{array}$ & $\begin{array}{c}\text { Ol,P1,Cpx } \\
(51,52,53 \\
\text { essentially } \\
\text { aphyric) }\end{array}$ & $\begin{array}{c}30,31, \\
32 / 35 \\
36\end{array}$ & $\begin{array}{l}51 \mathrm{a}, 51 \mathrm{c}, 55,56,57,58,59,61,62 \mathrm{~b}-\mathrm{d}, \\
63 \text { not analyzed }\end{array}$ \\
\hline $\mathrm{X}$ & $\mathrm{Hi} \mathrm{Zr}_{\mathrm{r}}$ & 64 & $\begin{array}{l}47-2,45- \\
48-3,100\end{array}$ & $\begin{array}{l}530- \\
539.5\end{array}$ & $\mathrm{Ol}, \mathrm{Pl}, \mathrm{Cpx}$ & 37 & 65 not analyzed. \\
\hline $\mathrm{Y}$ & Low $\mathrm{Zr}$ & 66 & $\begin{array}{l}49-1,30- \\
50-1,50\end{array}$ & $545-?$ & aphyric & 37 & \\
\hline
\end{tabular}

$\mathrm{a} /$ or - indicate major jump in inclination $\left(10-40^{\circ}\right)$. 
TABLE 11

Average Olivine Tholeiite Composition for Volcanoes of the Hawaiian-Emperor Chain ${ }^{\text {a }}$

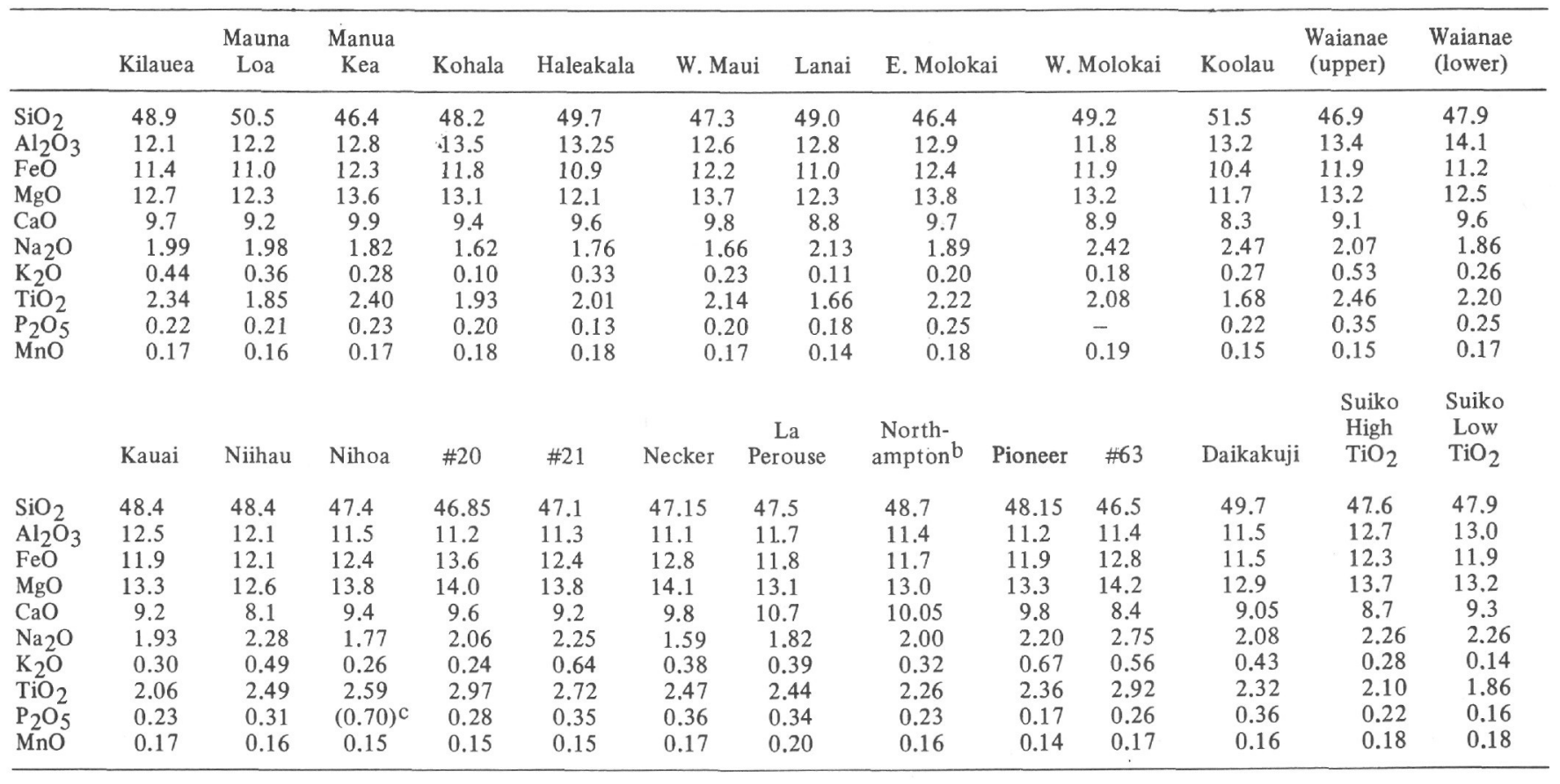

${ }^{a}$ Data are arranged as a function of distance from Kilauea. Volcano numbers of Bargar et al. (1974) are used for unnamed seamounts. Compositions are averages of dry reduced, normalized analyses of tholeiitic basalts with $\mathrm{MgO}=8 \%$. Olivine (Fo86) was added or subtracted so that $100 \mathrm{Mg} /(\mathrm{Mg}+0.85 \mathrm{Fe})=70$.

bata from M. O. Garcia, personal communication, 1978.

c Probably phosphatized.

Data for this table comes from Beeson, 1976; Bonhommet et al., 1977; Dalrymple et al., 1974; Macdonald, 1968; Macdonald and Katsura, 1964; Muir and Tilley, 1961; Wright, 1971; Wright and Fiske, 1971; and unpublished data of M. H. Beeson, D. Clague, and E. D. Jackson.

TABLE 12

Average Chemical Analyses of Lavas Recovered on Leg 55

\begin{tabular}{|c|c|c|c|c|c|c|c|c|}
\hline & \multicolumn{2}{|c|}{$\begin{array}{l}\text { Ojin Seamount } \\
\quad \text { (Site 430) }\end{array}$} & \multirow{2}{*}{$\begin{array}{l}\text { Nintoku Seamount } \\
\text { (Site 432) } \\
\text { Alkalic } \\
\text { Basalt }\end{array}$} & \multirow[b]{2}{*}{$\begin{array}{l}\text { Alkalic } \\
\text { Basalt }\end{array}$} & \multicolumn{3}{|c|}{$\begin{array}{l}\text { Suiko Seamount } \\
\text { (Site 433) }\end{array}$} & \multirow[b]{2}{*}{ Tholeiite } \\
\hline & Hawaiite & Tholeiite & & & $\begin{array}{l}\text { Picritic } \\
\text { Tholeiite }\end{array}$ & $\begin{array}{l}\text { Olivine } \\
\text { Tholeiite }\end{array}$ & $\begin{array}{l}\text { Plagioclase } \\
\text { Tholeiite }\end{array}$ & \\
\hline $\mathrm{SiO}_{2}$ & 47.8 & 47.7 & 46.3 & 46.5 & 43.3 & 45.7 & 47.2 & 46.6 \\
\hline $\mathrm{Al}_{2} \mathrm{O}_{3}$ & 15.9 & 15.3 & 16.5 & 14.3 & 9.0 & 13.4 & 14.6 & 14.3 \\
\hline $\mathrm{Fe}_{2} \mathrm{O}_{3}$ & 8.0 & 4.5 & 6.3 & 6.2 & 3.4 & 5.1 & 4.7 & 6.0 \\
\hline $\mathrm{FeO}$ & 4.1 & 7.9 & 6.2 & 7.8 & 8.8 & 7.1 & 7.2 & 6.6 \\
\hline $\mathrm{MgO}$ & 3.8 & 5.6 & 5.1 & 5.9 & 21.2 & 10.4 & 7.0 & 6.8 \\
\hline $\mathrm{CaO}$ & 6.6 & 11.0 & 8.6 & 9.3 & 5.0 & 8.9 & 10.1 & 9.9 \\
\hline $\mathrm{Na}_{2} \mathrm{O}$ & 4.3 & 3.0 & 3.6 & 3.4 & 1.2 & 2.4 & 2.8 & 2.9 \\
\hline $\mathrm{K}_{2} \mathrm{O}$ & 1.7 & 0.36 & 1.2 & 0.87 & 0.21 & 0.30 & 0.39 & 0.54 \\
\hline $\mathrm{H}_{2} \mathrm{O}^{+}$ & 1.2 & 0.39 & 1.5 & 1.1 & 4.6 & 2.3 & 1.1 & 1.2 \\
\hline $\mathrm{H}_{2} \mathrm{O}^{-}$ & 2.1 & 1.0 & 1.3 & 1.0 & 1.4 & 2.1 & 2.2 & 2.2 \\
\hline $\mathrm{TiO}_{2}$ & 2.9 & 2.8 & 2.7 & 3.0 & 1.2 & 2.2 & 2.3 & 2.5 \\
\hline $\mathrm{P}_{2} \mathrm{O}_{5}$ & 1.2 & 0.30 & 0.50 & 0.39 & 0.11 & 0.22 & 0.25 & 0.26 \\
\hline $\mathrm{MnO}$ & 0.10 & 0.18 & 0.15 & 0.19 & 0.16 & 0.17 & 0.14 & 0.16 \\
\hline $\mathrm{CO}_{2}$ & 0.06 & 0.04 & 0.10 & 0.05 & 0.05 & 0.10 & 0.05 & 0.32 \\
\hline Total & 99.8 & 100.1 & 100.0 & 100.0 & 99.6 & 100.4 & 100.0 & 100.3 \\
\hline
\end{tabular}


APPENDIX

Petrographic Summary for Site 433 Basalts

\begin{tabular}{|c|c|c|c|c|c|c|c|c|c|c|c|}
\hline \multirow[b]{2}{*}{ Hole } & \multirow[b]{2}{*}{$\begin{array}{l}\text { Core-Section, } \\
\text { Interval }(\mathrm{cm})\end{array}$} & \multirow[b]{2}{*}{$\begin{array}{l}\text { Flow } \\
\text { Unit }\end{array}$} & \multirow[b]{2}{*}{ Rock Type } & \multicolumn{3}{|c|}{ Phenocrysts \& Microphenocrysts } & \multicolumn{4}{|c|}{ Vesicles } & \multirow{2}{*}{$\begin{array}{l}\text { Groundmass } \\
\text { Per cent }\end{array}$} \\
\hline & & & & Mineral & Per cent & $\begin{array}{l}\text { A verage } \\
\text { Size } \\
(\mathrm{mm})\end{array}$ & Per cent & $\begin{array}{c}\text { Size } \\
\text { Range } \\
(\mathrm{mm})\end{array}$ & $\begin{array}{c}\text { Average } \\
\text { Size } \\
(\mathrm{mm})\end{array}$ & Shape & \\
\hline $433 \mathrm{~A}$ & $20-1,30-36$ & 1 & $\begin{array}{l}\text { Alkalic } \\
\text { Basalt }\end{array}$ & $\begin{array}{l}\text { pl } \\
\text { ol } \\
\text { cpx: }\end{array}$ & $\begin{array}{r}4 \\
<1 \\
<1\end{array}$ & $\begin{array}{l}0.62 \\
0.58 \\
0.51\end{array}$ & & & & & $95^{+}$ \\
\hline & $21-2,86-90$ & 1 & $\begin{array}{l}\text { Alkalic } \\
\text { Basalt }\end{array}$ & $\begin{array}{l}\mathrm{pl} \\
\mathrm{cpx} \\
\mathrm{ol}\end{array}$ & $\begin{array}{r}12 \\
4 \\
1\end{array}$ & $\begin{array}{l}3.13 \\
0.97 \\
0.55\end{array}$ & & & & & 83 \\
\hline & $21-3,115-123$ & 1 & $\begin{array}{l}\text { Alkalic } \\
\text { Basalt }\end{array}$ & $\begin{array}{l}\mathrm{pl} \\
\mathrm{cpx} \\
\text { ol }\end{array}$ & $\begin{array}{l}6 \\
1 \\
1\end{array}$ & $\begin{array}{r}1.25 \\
.62 \\
1.29\end{array}$ & 1 & $0.70-1.70$ & 0.81 & ovoid & 92 \\
\hline & $21-4,129-138$ & 1 & $\begin{array}{l}\text { Alkalic } \\
\text { Basalt }\end{array}$ & $\begin{array}{l}\mathrm{pl} \\
\mathrm{cpx} \\
\mathrm{ol}\end{array}$ & $\begin{array}{r}12 \\
4 \\
<1\end{array}$ & $\begin{array}{l}2.18 \\
0.54 \\
0.55\end{array}$ & 4 & $0.32-1.50$ & 0.80 & ovoid & $83^{+}$ \\
\hline \multirow[t]{2}{*}{ 433B } & $5-2,61-68$ & 1 & $\begin{array}{l}\text { Alkalic } \\
\text { Basalt }\end{array}$ & $\begin{array}{l}\mathrm{pl} \\
\mathrm{cpx} \\
\mathrm{ol}\end{array}$ & $\begin{array}{r}3 \\
2 \\
<1\end{array}$ & $\begin{array}{l}1.35 \\
0.56 \\
0.70\end{array}$ & 1 & $0.15-0.41$ & 0.32 & ovoid & 95 \\
\hline & $5-3,85-90$ & 2 & $\begin{array}{l}\text { Alkalic } \\
\text { Basalt }\end{array}$ & $\begin{array}{l}\mathrm{pl} \\
\mathrm{ol} \\
\mathrm{cpx}\end{array}$ & $\begin{array}{l}9 \\
7 \\
2\end{array}$ & $\begin{array}{l}1.00 \\
1.51 \\
0.73\end{array}$ & & & & & $81^{+}$ \\
\hline $433 \mathrm{C}$ & $4-1,30-38$ & 2 & $\begin{array}{l}\text { Alkalic } \\
\text { Basalt }\end{array}$ & $\begin{array}{l}\mathrm{pl} \\
\mathrm{ol} \\
\mathrm{cpx} \\
\mathrm{mt}\end{array}$ & $\begin{array}{r}12 \\
7 \\
2 \\
<1\end{array}$ & $\begin{array}{l}1.44 \\
2.16 \\
1.15 \\
0.46\end{array}$ & & & & & $78^{+}$ \\
\hline $433 \mathrm{C}$ & $5-1,2-9$ & 2 & $\begin{array}{l}\text { Alkalic } \\
\text { Basalt }\end{array}$ & $\begin{array}{l}\text { ol } \\
\mathrm{pl} \\
\mathrm{cpx}\end{array}$ & $\begin{array}{l}7 \\
7 \\
4\end{array}$ & $\begin{array}{l}2.40 \\
1.71 \\
1.50\end{array}$ & & & & & 82 \\
\hline
\end{tabular}




\section{APPENDIX - Continued}

\begin{tabular}{|c|c|c|c|c|c|c|}
\hline \multicolumn{5}{|c|}{ Groundmass } & \multirow[b]{2}{*}{ Alteration and Remarks $b$} & \multirow[b]{2}{*}{ Other Work } \\
\hline $\begin{array}{l}\text { Dominant } \\
\text { Texture }\end{array}$ & $\begin{array}{l}\text { Size Range } \\
(\mathrm{mm})\end{array}$ & Minerals ${ }^{\mathrm{a}}$ & Per cent & Opaque Minerals & & \\
\hline $\begin{array}{l}\text { microlitic, } \\
\text { intergranular }\end{array}$ & $\begin{array}{l}0.02-0.10 \\
0.01-0.05 \\
0.001-0.02 \\
0.01-0.08\end{array}$ & $\begin{array}{l}\mathrm{pl} \\
\mathrm{cpx} \\
\mathrm{mt} \\
\mathrm{ol}\end{array}$ & $\begin{array}{r}50-55 \\
20-25 \\
10-12 \\
8-10\end{array}$ & $\begin{array}{l}\text { Equant timag., with ilmenite } \\
\text { exsolution lamellae. }\end{array}$ & $\begin{array}{l}10-12 \% \text { altered, ol completely } \\
\text { replaced by smectite. Smec- } \\
\text { tite has basal } d=13.18 \AA \text { which } \\
\text { expands to } 16.98 \AA \text { after } \\
\text { glycol. Mainly smectite A } \\
\text { but trace of chlorite(?) and B } \\
\text { also. Sector zoned cpx. }\end{array}$ & $\mathrm{X}, \mathrm{T}, \mathrm{S}, \mathrm{K}, \mathrm{M}$ \\
\hline subtrachytic & $\begin{array}{l}0.02-1.20 \\
0.006-0.50 \\
0.005-0.15 \\
0.01-0.50 \\
0.01-0.17\end{array}$ & $\begin{array}{l}\mathrm{pl} \\
\mathrm{cpx} \\
\mathrm{mt} \\
\text { ol } \\
\text { il }\end{array}$ & $\begin{array}{r}57 \\
18 \\
4 \\
3 \\
1\end{array}$ & & $\begin{array}{l}10 \% \text { altered, ol completely } \\
\text { replaced by calcite and smec- } \\
\text { tite. Smectite has basal } d= \\
13.59 \AA \text { which expands to } \\
16.98 \AA \text { after glycol. Mainly } \\
\text { smectite } A \text { but trace of B } \\
\text { also. Sector zoned cpx. }\end{array}$ & \\
\hline subtrachytic & $\begin{array}{l}0.05-0.90 \\
0.01-0.50 \\
0.002-0.18 \\
0.02-0.50 \\
0.01-0.15\end{array}$ & $\begin{array}{l}\mathrm{pl} \\
\mathrm{cpx} \\
\mathrm{mt} \\
\text { ol } \\
\text { il }\end{array}$ & $\begin{array}{r}57 \\
23 \\
6 \\
5 \\
1\end{array}$ & & $\begin{array}{l}12 \% \text { altered, ol completely re- } \\
\text { placed by smectite. Smectite } \\
\text { has basal } d=12.80 \AA \text { which ex- } \\
\text { pands to } 17.31 \AA \text { after glycol. } \\
\text { Mainly smectite A but trace } \\
\text { of B and chlorite(?) also. } \\
\text { Sector zoned cpx. }\end{array}$ & \\
\hline intergranular & $\begin{array}{l}0.05-1.50 \\
0.01-0.50 \\
0.002-0.25 \\
0.01-0.50 \\
0.008-0.20 \\
0.01-0.15\end{array}$ & $\begin{array}{l}\mathrm{pl} \\
\mathrm{cpx} \\
\mathrm{mt} \\
\text { ol } \\
\text { il } \\
\text { ap }\end{array}$ & $\begin{array}{r}38 \\
31 \\
6 \\
4 \\
2 \\
2\end{array}$ & $\begin{array}{l}\text { Equant timag. and equant } \\
\text { ilmenite. Pyrite is present. } \\
\text { Olivine phenocrysts contain } \\
\text { chromite. }\end{array}$ & $\begin{array}{l}14 \% \text { altered, ol completely } \\
\text { replaced by smectite and } \\
\text { iddingsite. Smectite has a } \\
\text { basal } d=14.02 \AA \text { which ex- } \\
\text { pands to } 16.98 \AA \text { after glycol. } \\
\text { Vesicles filled with fibrous } \\
\text { olive-green smectite. Sector } \\
\text { zoned cpx. }\end{array}$ & $\begin{array}{l}\mathrm{W}, \mathrm{X}, \mathrm{T}, \mathrm{S} \\
\mathrm{K}, \mathrm{M}\end{array}$ \\
\hline subtrachy tic & $\begin{array}{l}0.05-0.90 \\
0.006-0.50 \\
0.001-0.10 \\
0.01-0.50\end{array}$ & $\begin{array}{l}\mathrm{pl} \\
\mathrm{cpx} \\
\mathrm{mt} \\
\mathrm{ol}\end{array}$ & $\begin{array}{r}60 \\
5 \\
8 \\
2\end{array}$ & $\begin{array}{l}\text { Equant timag. and ilmenite. } \\
\text { Some timag. have ilmenite } \\
\text { exsolution. Pyrite and } \\
\text { chalcopyrite present. }\end{array}$ & $\begin{array}{l}6 \% \text { altered, ol completely re- } \\
\text { placed by olive green smec- } \\
\text { tite. Smectite has basal } d= \\
14.48 \AA \text { which splits to form } \\
\text { two peaks, } d=14.72 \text { and } d= \\
16.98 \AA \text { after glycol. Mainly } \\
\text { smectite A but trace of B and } \\
\text { chlorite(?) also. Sector } \\
\text { zoned cpx. }\end{array}$ & $\mathrm{P}, \mathrm{R} 2, \mathrm{~S}, \mathrm{~K}, \mathrm{M}$ \\
\hline $\begin{array}{l}\text { microlitic, } \\
\text { intergranular }\end{array}$ & $\begin{array}{l}0.05-0.96 \\
0.002-0.20 \\
0.001-0.05 \\
0.01-0.20\end{array}$ & $\begin{array}{l}\mathrm{pl} \\
\mathrm{cpx} \\
\mathrm{mt} \\
\mathrm{ol}\end{array}$ & $\begin{array}{r}46 \\
16 \\
12 \\
7\end{array}$ & $\begin{array}{l}\text { Timag. in groundmass } \\
\text { Olivine phenocrysts con- } \\
\text { tain chromite. }\end{array}$ & $\begin{array}{l}6 \% \text { altered, ol almost com- } \\
\text { pletely replaced by green } \\
\text { smectite with iddingsite rims. } \\
\text { Smectite has basal } d=14.72 \AA \\
\text { which expands to } 16.66 \AA \text { after } \\
\text { glycol. Smectite B only. Sec- } \\
\text { tor zoned cpx phenocrysts. } \\
\text { Rare large ol have kink-bands. }\end{array}$ & $\mathrm{X}, \mathrm{T}, \mathrm{M}$ \\
\hline $\begin{array}{l}\text { microlitic, } \\
\text { intergranular }\end{array}$ & $\begin{array}{l}0.02-1.70 \\
0.005-0.50 \\
0.003-0.20 \\
0.01-0.50 \\
0.03-0.06\end{array}$ & $\begin{array}{l}\mathrm{pl} \\
\mathrm{cpx} \\
\mathrm{mt} \\
\text { ol } \\
\text { il }\end{array}$ & $\begin{array}{r}44 \\
22 \\
7 \\
5 \\
<1\end{array}$ & $\begin{array}{l}\text { Timag. and ilmenite. } \\
\text { Pyrite and chalcopyrite are } \\
\text { present, and olivine pheno- } \\
\text { crysts contain chromite } \\
\text { that is zoned to chrome- } \\
\text { rich timag. on rims. }\end{array}$ & $\begin{array}{l}7 \% \text { altered, ol altered to olive } \\
\text { brown smectite on rims and } \\
\text { cracks. Smectite has basal } \\
d=14.24 \AA \text { and } 15.22 \AA \text { which } \\
\text { expand to } 14.72 \text { and } 17.31 \AA \\
\text { after glycol. Only smectite B } \\
\text { and chlorite(?) are present. } \\
\text { Rare large ol have kink-bands. }\end{array}$ & $\begin{array}{l}\mathrm{S}, \mathrm{P}, \mathrm{T}, \mathrm{R} 2 \\
\mathrm{~S}, \mathrm{~K}, \mathrm{M}\end{array}$ \\
\hline intergranular & $\begin{array}{l}0.03-0.50 \\
0.005-0.50 \\
0.03-0.50 \\
0.001-0.10 \\
0.01-0.34\end{array}$ & $\begin{array}{l}\mathrm{pl} \\
\mathrm{cpx} \\
\text { ol } \\
\mathrm{mt} \\
\text { il }\end{array}$ & $\begin{array}{r}45 \\
22 \\
7 \\
7 \\
1\end{array}$ & & $\begin{array}{l}16 \% \text { altered, ol altered to } \\
\text { iddingsite and olive smectite on } \\
\text { rims and cracks. Smectice has } \\
\text { basal } d=13.38 \AA \text { and } 14.48 \AA \\
\text { which expands to } 14.72 \text { and } \\
16.66 \AA \text { after glycol. Only } \\
\text { chlorite(?) and smectite B are } \\
\text { present. Phillipsite identified } \\
\text { bv XRD. Rare large ol have } \\
\text { kink-bands. }\end{array}$ & \\
\hline
\end{tabular}


APPENDIX - Continued

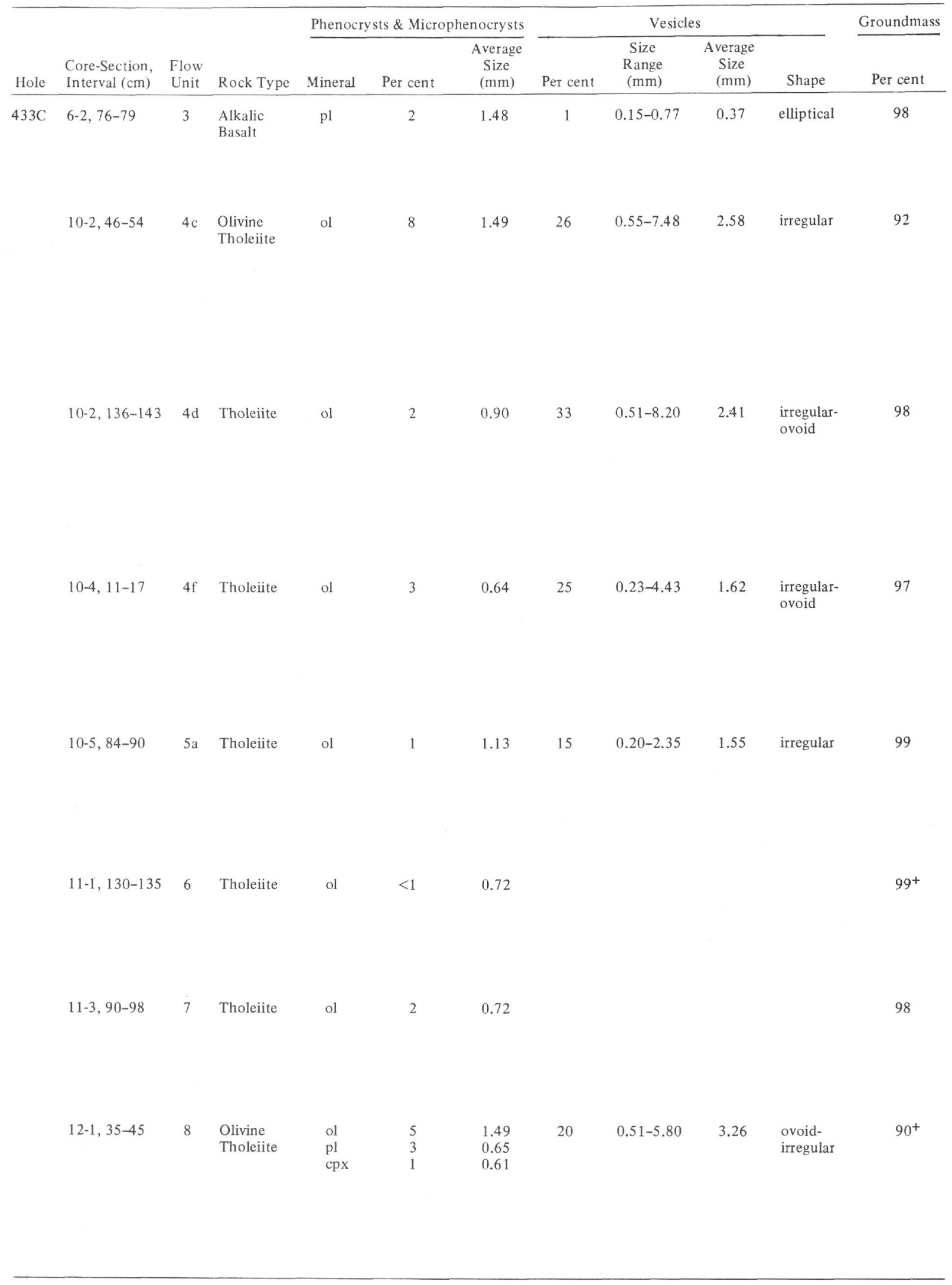


APPENDIX - Continued

\begin{tabular}{|c|c|c|c|c|c|c|}
\hline \multicolumn{5}{|c|}{ Groundmass } & \multirow[b]{2}{*}{ Alteration and Remarks b } & \multirow[b]{2}{*}{ Other Work } \\
\hline $\begin{array}{l}\text { Dominant } \\
\text { Texture }\end{array}$ & $\begin{array}{l}\text { Size Range } \\
(\mathrm{mm})\end{array}$ & Minerals $^{\mathrm{a}}$ & Per cent & Opaque Minerals & & \\
\hline pilotaxitic & $\begin{array}{l}0.005-0.75 \\
0.001-0.50 \\
0.001-0.10 \\
0.003-0.50 \\
0.005-0.01 \\
\text { up to } 0.01\end{array}$ & $\begin{array}{l}\mathrm{pl} \\
\mathrm{cpx} \\
\mathrm{mt} \\
\text { ol } \\
\text { il } \\
\text { ap }\end{array}$ & $\begin{array}{c}30-35 \\
25-30 \\
18-20 \\
12-15 \\
1-2 \\
1\end{array}$ & & $\begin{array}{l}10-15 \% \text { altered, ol completely } \\
\text { replaced by smectite and } \\
\text { iddingsite. Smectite has basal } \\
d=14.02 \AA \text { which expands to } \\
16.98 \AA \text { after glycol. Only } \\
\text { smectite B is present. }\end{array}$ & $\mathrm{X}, \mathrm{P}, \mathrm{T}, \mathrm{R} 2$ \\
\hline $\begin{array}{l}\text { ophitic- } \\
\text { sub-ophitic }\end{array}$ & $\begin{array}{ll}0.01 & -0.55 \\
0.01 & -0.55 \\
0.01 & -0.48 \\
0.001 & -0.01 \\
0.01 & -0.15\end{array}$ & $\begin{array}{l}\text { pl } \\
\text { cpx } \\
\text { ol } \\
\mathrm{mt} \\
\text { il }\end{array}$ & $\begin{array}{r}43 \\
37 \\
7 \\
4 \\
1\end{array}$ & & $\begin{array}{l}42 \% \text { altered, ol completely re- } \\
\text { placed by smectite and idding- } \\
\text { site. Pl mostly replaced by } \\
\text { smectite and kf. Vesicles lined } \\
\text { with fibrous pale green smec- } \\
\text { tite. Smectite has basal } d= \\
12.27 \text { and } 14.24 \AA \text { which ex- } \\
\text { pands to } 14.72 \text { and } 16.98 \AA \\
\text { after glycol. Smectite A, B and } \\
\text { chlorite(?) are present. Some } \\
\text { cpx is altered to amphibole(?). }\end{array}$ & \\
\hline sub-ophitic & $\begin{array}{ll}0.01 & -1.22 \\
0.01 & -0.50 \\
0.01 & -0.50 \\
0.005 & -0.10 \\
0.01 & -0.20\end{array}$ & $\begin{array}{l}\text { pl } \\
\mathrm{cpx} \\
\text { ol } \\
\mathrm{mt} \\
\text { il }\end{array}$ & $\begin{array}{r}55 \\
27 \\
10 \\
4 \\
3\end{array}$ & & $\begin{array}{l}22 \% \text { altered, ol completely re- } \\
\text { placed by smectite and idding- } \\
\text { site. Pl is about half altered to } \\
\text { smectite. Vesicles are lined } \\
\text { with pale green fibrous smec- } \\
\text { tite. Smectite has basal } d= \\
13.59 \AA \text { which expands to } \\
16.66 \AA \text { after glycol. Both } \\
\text { smectite A and B are present. } \\
\text { Some cpx altered to amphibole. }\end{array}$ & \\
\hline sub-ophitic & $\begin{array}{ll}0.01 & -0.95 \\
0.01 & -0.20 \\
0.01 & -0.50 \\
0.005 & -0.05 \\
0.01 & -0.16\end{array}$ & $\begin{array}{l}\text { pl } \\
\mathrm{cpx} \\
\text { ol } \\
\mathrm{mt} \\
\text { il }\end{array}$ & $\begin{array}{r}41 \\
32 \\
19 \\
3 \\
3\end{array}$ & $\begin{array}{l}\text { Exsolved skeletal timag. } \\
\text { Olivine phenocrysts contain } \\
\text { chromite that is zoned to } \\
\text { chrome-rich timag. on } \\
\text { rims. Single grain of } \\
\text { magnesioferrite. }\end{array}$ & $\begin{array}{l}31 \% \text { altered, ol completely re- } \\
\text { placed by smectite and idding- } \\
\text { site. Pl is about } 50 \% \text { replaced } \\
\text { by smectite. Cpx is partly re- } \\
\text { placed by amphibole(?). Smec- } \\
\text { tite has basal } d=12.80 \AA \text { which } \\
\text { expands to } 16.98 \AA \text { after glycol. } \\
\text { Mainly smectite B but trace } \\
\text { of A also. }\end{array}$ & $\mathrm{X}, \mathrm{T}, \mathrm{M}$ \\
\hline ophitic & $\begin{array}{l}0.01-0.25 \\
0.005-0.25 \\
0.01-0.50 \\
0.005-0.10\end{array}$ & $\begin{array}{l}\mathrm{pl} \\
\mathrm{cpx} \\
\mathrm{ol} \\
\mathrm{mt}\end{array}$ & $\begin{array}{r}50 \\
40 \\
5 \\
4\end{array}$ & & $\begin{array}{l}43 \% \text { altered, ol completely re- } \\
\text { placed by calcite, smectite, and } \\
\text { iddingsite. Most vesicles are } \\
\text { filled with fibrous yellow-green } \\
\text { smectite. Smectite has basal } \\
d=12.80 \AA \text { which expands to } \\
17.66 \AA \text { after glycol. Only } \\
\text { smectite A present. }\end{array}$ & \\
\hline ophitic & $\begin{array}{ll}0.01 & -0.60 \\
0.01 & -0.50 \\
0.01 & -0.50 \\
0.01 & -0.30 \\
0.005 & -0.20\end{array}$ & $\begin{array}{l}\mathrm{pl} \\
\mathrm{cpx} \\
\text { ol } \\
\text { il } \\
\mathrm{mt}\end{array}$ & $\begin{array}{r}53 \\
31 \\
13 \\
2 \\
<1\end{array}$ & & $\begin{array}{l}38 \% \text { altered, ol completely re- } \\
\text { placed by calcite, smectite, and } \\
\text { iddingsite. Smectite has basal } \\
d=12.62 \AA \text { and } 14.97 \AA \text { (chlo- } \\
\text { rite?) which expands to } 17.31 \AA \\
\text { after glycol. Mainly smectite A, } \\
\text { but trace of B also. }\end{array}$ & \\
\hline sub-ophitic & $\begin{array}{l}0.02-0.70 \\
0.001-0.30 \\
0.01-0.50 \\
0.005-0.25 \\
0.001-0.05\end{array}$ & $\begin{array}{l}\mathrm{pl} \\
\mathrm{cpx} \\
\text { ol } \\
\text { il } \\
\mathrm{mt}\end{array}$ & $\begin{array}{r}46 \\
33 \\
12 \\
4 \\
2\end{array}$ & & $\begin{array}{l}\sim 36 \% \text { altered, ol completely re- } \\
\text { placed by smectite and idding- } \\
\text { site. Smectite has basal } d= \\
14.24 \text { and } 14.97 \AA \text { (chlorite?) } \\
\text { which expands to } 16.98 \AA \text { after } \\
\text { glycol. Both smectite A and B } \\
\text { present. }\end{array}$ & \\
\hline intergranular & $\begin{array}{l}0.005-1.00 \\
0.01-0.50 \\
0.01-0.50 \\
0.01-0.25 \\
0.005-0.05\end{array}$ & $\begin{array}{l}\mathrm{pl} \\
\mathrm{cpx} \\
\text { ol } \\
\text { il } \\
\mathrm{mt}\end{array}$ & $\begin{array}{r}44 \\
35 \\
4 \\
4 \\
3\end{array}$ & & $\begin{array}{l}\sim 40 \% \text { altered, ol totally re- } \\
\text { placed by calcite, smectite, and } \\
\text { iddingsite. Some pl cores } \\
\text { altered to clays and } \mathrm{kf}(?) \text {. } \\
\text { Vesicles lined with green fibrous } \\
\text { smectite and calcite. Smectite } \\
\text { has basal } d=12.62 \AA \text { which ex- } \\
\text { pands to } 17.31 \AA \text { after glycol. } \\
\text { Only smectite A present. }\end{array}$ & \\
\hline
\end{tabular}


APPENDIX - Continued

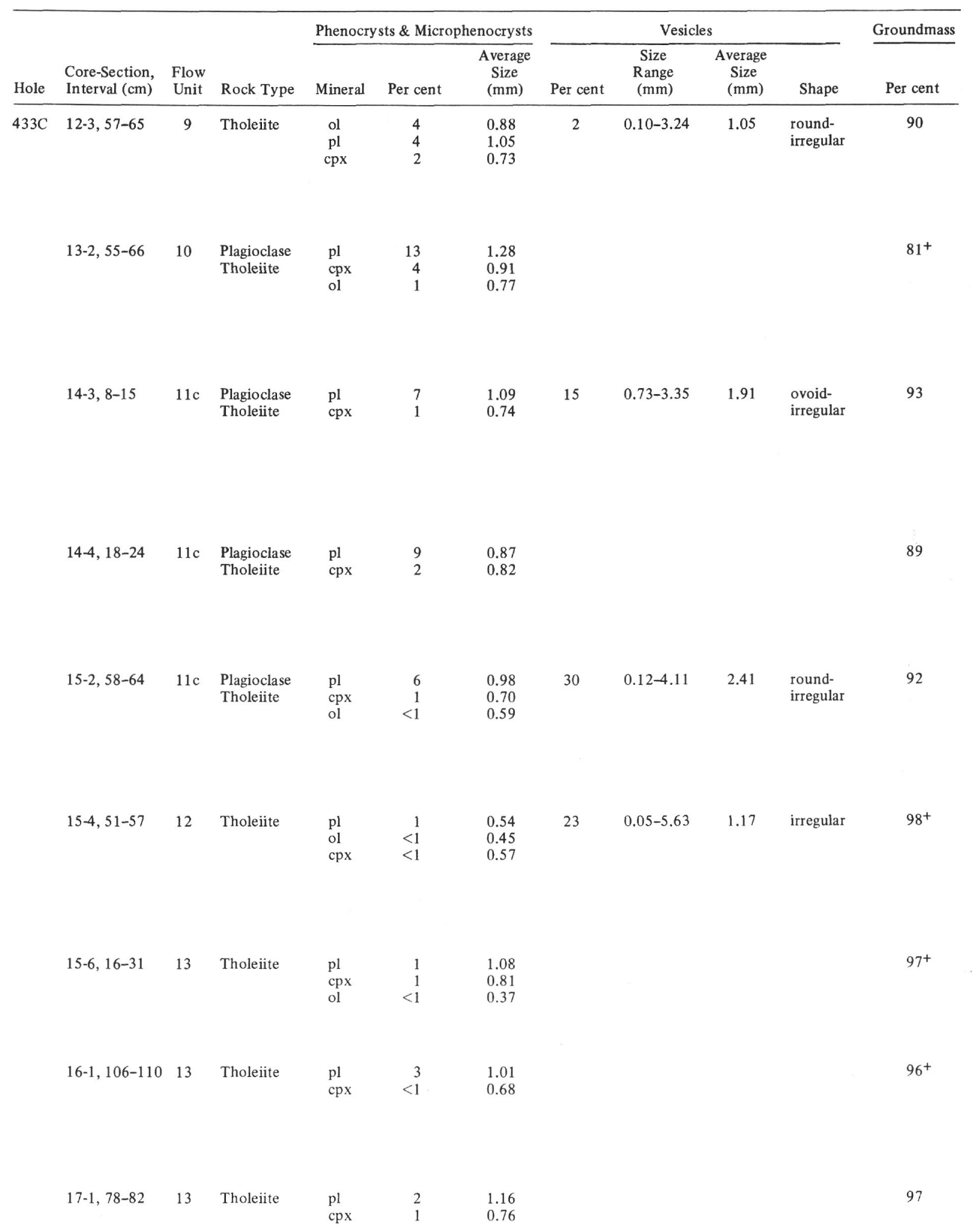


APPENDIX - Continued

\begin{tabular}{|c|c|c|c|c|c|c|}
\hline \multicolumn{5}{|c|}{ Groundmass } & \multirow[b]{2}{*}{ Alteration and Remarks ${ }^{b}$} & \multirow[b]{2}{*}{ Other Work } \\
\hline $\begin{array}{l}\text { Dominant } \\
\text { Texture }\end{array}$ & $\begin{array}{l}\text { Size Range } \\
(\mathrm{mm})\end{array}$ & Minerals $^{\mathrm{a}}$ & Per cent & Opaque Minerals & & \\
\hline $\begin{array}{l}\text { microlitic- } \\
\text { intergranular }\end{array}$ & $\begin{array}{l}0.003-0.50 \\
0.01-1.10 \\
0.01-0.50 \\
0.001-0.05 \\
0.01-0.05\end{array}$ & $\begin{array}{l}\mathrm{cpx} \\
\mathrm{p} 1 \\
\mathrm{ol} \\
\mathrm{mt} \\
\text { il }\end{array}$ & $\begin{array}{r}46 \\
33 \\
5 \\
3 \\
3\end{array}$ & $\begin{array}{l}\text { Tiny equant exsolved } \\
\text { timag. Rare elongate } \\
\text { crystals may be } \\
\text { ilmenite. }\end{array}$ & $\begin{array}{l}16 \% \text { altered, ol totally re- } \\
\text { placed by olive-green smectite } \\
\text { and iddingsite. Smectite has } \\
\text { basal } d=12.80 \AA \text { which splits to } \\
\text { a } d=14.72 \AA \text { (chlorite?) and a } \\
17.31 \AA \text { peak after glycol. Only } \\
\text { smectite A is present. }\end{array}$ & $\mathrm{X}, \mathrm{T}, \mathrm{M}$ \\
\hline intergranular & $\begin{array}{ll}0.05 & -1.20 \\
0.01 & -0.50 \\
0.05 & -0.50 \\
0.01 & -0.70 \\
0.005 & -0.26\end{array}$ & $\begin{array}{l}\mathrm{pl} \\
\mathrm{cpx} \\
\mathrm{ol} \\
\text { il } \\
\mathrm{mt}\end{array}$ & $\begin{array}{r}44 \\
26 \\
7 \\
3 \\
1\end{array}$ & $\begin{array}{l}\text { Equant exsolved timag. } \\
\text { and elongate ilmenite. } \\
\text { Pyrite is present. }\end{array}$ & $\begin{array}{l}25 \% \text { altered, ol totally replaced } \\
\text { by fibrous olive smectite. Smec- } \\
\text { tite has basal } d=13.38 \AA \text { which } \\
\text { splits to form two peaks, } d= \\
14.48 \text { and } 16.66 \AA \text { after glycol. } \\
\text { Both smectite } \mathrm{A} \text { and } \mathrm{B} \text {, and } \\
\text { chlorite(?) present. Pl pheno- } \\
\text { crysts contain glass inclusions. }\end{array}$ & $\mathrm{X}, \mathrm{T}, \mathrm{R} 1, \mathrm{M}$ \\
\hline intergranular & $\begin{array}{ll}0.01 & -0.85 \\
0.01 & -0.50 \\
0.01 & -0.50 \\
0.01 & -0.20 \\
0.001 & -0.05\end{array}$ & $\begin{array}{l}\text { pl } \\
\mathrm{cpx} \\
\text { ol } \\
\text { il } \\
\mathrm{mt}\end{array}$ & $\begin{array}{r}43 \\
36 \\
7 \\
5 \\
2\end{array}$ & $\begin{array}{l}\text { Skeletal exsolved timag. } \\
\text { and elongate ilmenite. }\end{array}$ & $\begin{array}{l}21 \% \text { altered, ol totally altered } \\
\text { to smectite and iddingsite. } \\
\text { Smectite has basal } d=12.99 \AA \\
\text { which expands to } 17.31 \AA \text { after } \\
\text { glycol. Only smectite A } \\
\text { present. Vesicles lined with } \\
\text { fibrous olive green smectite. } \\
\text { Some pl cores are replaced by } \\
\text { phillipsite(?) or kf. }\end{array}$ & $\mathrm{X}, \mathrm{T}, \mathrm{R} 1, \mathrm{M}$ \\
\hline sub-ophitic & $\begin{array}{ll}0.01 & -0.72 \\
0.01 & -0.50 \\
0.001 & -0.15 \\
0.02 & -0.20 \\
0.01 & -0.40\end{array}$ & $\begin{array}{l}\text { pl } \\
\text { cpx } \\
\text { mt } \\
\text { ol } \\
\text { il }\end{array}$ & $\begin{array}{r}48 \\
31 \\
6 \\
2 \\
2\end{array}$ & & $\begin{array}{l}23 \% \text { altered, ol totally altered } \\
\text { to smectite and iddingsite. } \\
\text { Smectite has basal } d=12.80 \AA \\
\text { which expands to } 17.31 \AA \\
\text { after glycol. Only smectite A } \\
\text { present. Some pl cores re- } \\
\text { placed by kf. }\end{array}$ & \\
\hline intersertal & $\begin{array}{ll}0.01 & -0.60 \\
0.01 & -0.25 \\
0.005 & -0.50 \\
0.001 & -0.07 \\
0.01 & -0.43\end{array}$ & $\begin{array}{l}\text { pl } \\
\text { cpx } \\
\text { ol } \\
\text { mt } \\
\text { il }\end{array}$ & $\begin{array}{r}51 \\
26 \\
7 \\
5 \\
3\end{array}$ & & $\begin{array}{l}31 \% \text { altered, ol totally altered } \\
\text { to iddingsite and smectite. } \\
\text { Smectite has basal } d=13.59 \AA \\
\text { which expands to } 17.31 \AA \text { after } \\
\text { glycol. Some vesicles filled } \\
\text { with fibrous olive green smec- } \\
\text { tite. Only smectite A is } \\
\text { present. }\end{array}$ & \\
\hline $\begin{array}{l}\text { microlitic, } \\
\text { subtrachytic }\end{array}$ & $\begin{array}{l}0.01-0.50 \\
0.001-0.50 \\
0.001-0.05 \\
0.005-0.05 \\
0.01-0.50\end{array}$ & $\begin{array}{l}\text { pl } \\
\text { cpx } \\
\mathrm{mt} \\
\text { il } \\
\text { ol }\end{array}$ & $\begin{array}{r}50 \\
37 \\
8 \\
3 \\
1\end{array}$ & & $\begin{array}{l}40 \% \text { altered, ol totally altered } \\
\text { to smectite with iddingsite } \\
\text { rims. Smectite has basal } d= \\
12.80 \AA \text { which expands to } \\
17.31 \AA \text { after glycol. Only } \\
\text { smectite A is present. Most } \\
\text { vesicles are filled with fibrous } \\
\text { olive green smectite. }\end{array}$ & \\
\hline $\begin{array}{l}\text { subtrachytic, } \\
\text { microlitic }\end{array}$ & $\begin{array}{l}0.005-0.65 \\
0.001-0.50 \\
0.001-0.10 \\
0.01-0.10 \\
0.02-0.35\end{array}$ & $\begin{array}{l}\mathrm{pl} \\
\mathrm{cpx} \\
\mathrm{mt} \\
\text { il } \\
\text { ol }\end{array}$ & $\begin{array}{r}41 \\
44 \\
7 \\
4 \\
<1\end{array}$ & $\begin{array}{l}\text { Equant timag. with minor } \\
\text { ilmenite exsolution and } \\
\text { elongate ilmenite. }\end{array}$ & $\begin{array}{l}8 \% \text { altered, ol totally altered } \\
\text { to olive green-brown smec- } \\
\text { tite and iddingsite. Smectite } \\
\text { has basal } d=12.62 \AA \text { which ex- } \\
\text { pands to } 18.02 \AA \text { after glycol. } \\
\text { Only smectite A is present. }\end{array}$ & $\begin{array}{l}\mathrm{W}, \mathrm{X}, \mathrm{T}, \mathrm{S} \\
\mathrm{K}, \mathrm{M}\end{array}$ \\
\hline $\begin{array}{l}\text { microlitic, } \\
\text { intergranular }\end{array}$ & $\begin{array}{ll}0.01-1.08 \\
0.001-0.28 \\
0.05-0.20 \\
0.001-0.10 \\
0.01-0.10\end{array}$ & $\begin{array}{l}\text { pl } \\
\text { cpx } \\
\text { ol } \\
\mathrm{mt} \\
\text { il }\end{array}$ & $\begin{array}{r}52 \\
34 \\
5 \\
3 \\
2\end{array}$ & & $\begin{array}{l}4 \% \text { altered, ol mostly altered } \\
\text { to dark green-brown smectite. } \\
\text { Smectite has basal } d=14.02 \AA \\
\text { which expands to } 16.98 \AA \text { after } \\
\text { glycol. Only smectite } A \text { is } \\
\text { present. Rock is glomero- } \\
\text { porphyritic. }\end{array}$ & \\
\hline intergranular & $\begin{array}{l}0.01-1.05 \\
0.001-0.35 \\
0.008-0.23 \\
0.005-0.17 \\
0.005-0.48\end{array}$ & $\begin{array}{l}\text { pl } \\
\text { cpx } \\
\text { il } \\
\mathrm{mt} \\
\text { ol }\end{array}$ & $\begin{array}{r}50 \\
40 \\
4 \\
2 \\
1\end{array}$ & . & $\begin{array}{l}2 \% \text { altered, ol totally altered } \\
\text { to dark green-brown smec- } \\
\text { tite. Smectite has basal } d= \\
14.72 \AA \text { which splits to form } \\
\text { two peaks, } 14.72 \AA \text { (chlorite?) } \\
\text { and } 16.98 \AA \text { after glycol. Only } \\
\text { smectite } A \text { is present. }\end{array}$ & $\begin{array}{l}\text { W,X,P,R1, } \\
\text { S,K }\end{array}$ \\
\hline
\end{tabular}


APPENDIX - Continued

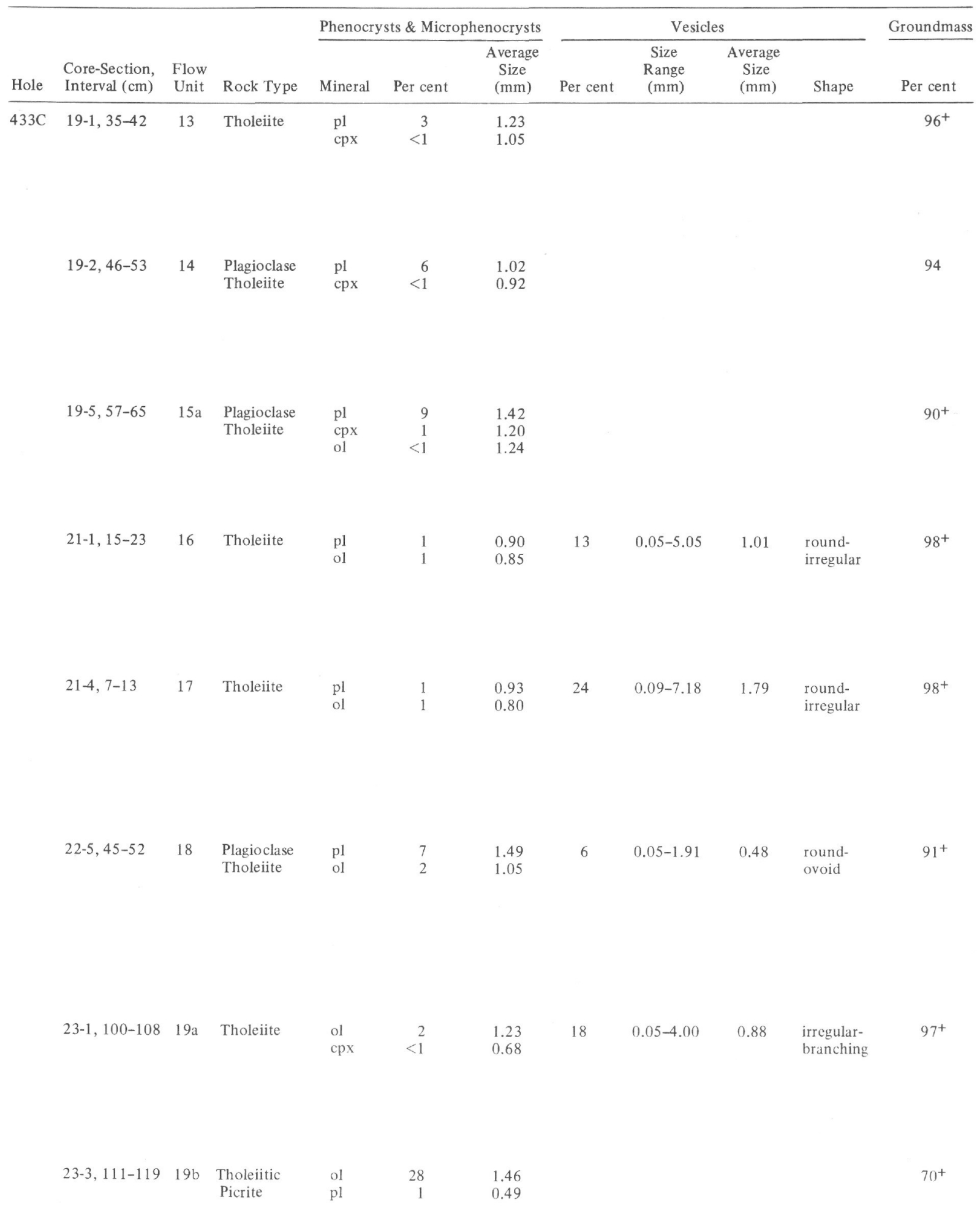


APPENDIX - Continued

\begin{tabular}{|c|c|c|c|c|c|c|}
\hline \multicolumn{5}{|c|}{ Groundmass } & \multirow[b]{2}{*}{ Alteration and Remarks $\mathrm{b}$} & \multirow[b]{2}{*}{ Other Work } \\
\hline $\begin{array}{l}\text { Dominant } \\
\text { Texture }\end{array}$ & $\begin{array}{l}\text { Size Range } \\
(\mathrm{mm})\end{array}$ & Minerals ${ }^{\mathrm{a}}$ & Per cent & Opaque Minerals & & \\
\hline sub-ophitic & $\begin{array}{l}0.005-1.00 \\
0.01-0.45 \\
0.003-0.06 \\
0.01-0.43 \\
0.005-0.07\end{array}$ & $\begin{array}{l}\mathrm{pl} \\
\mathrm{cpx} \\
\mathrm{mt} \\
\text { ol } \\
\text { il }\end{array}$ & $\begin{array}{r}50 \\
36 \\
8 \\
2 \\
1\end{array}$ & & $\begin{array}{l}27 \% \text { altered, ol totally altered } \\
\text { to dark green-brown smectite } \\
\text { and pleochroic iddingsite. } \\
\text { Smectite has basal } d=11.94 \AA \\
\text { which expands to } 18.79 \AA \text { after } \\
\text { glycol. Only smectite } \mathrm{A} \text { is } \\
\text { present. Rock is glomero- } \\
\text { porphyritic. }\end{array}$ & \\
\hline sub-ophitic & $\begin{array}{l}0.01-0.85 \\
0.005-0.50 \\
0.01-0.50 \\
0.005-0.10 \\
0.01-0.30\end{array}$ & $\begin{array}{l}\mathrm{pl} \\
\mathrm{cpx} \\
\text { ol } \\
\mathrm{mt} \\
\text { il }\end{array}$ & $\begin{array}{r}42 \\
42 \\
5 \\
3 \\
2\end{array}$ & & $\begin{array}{l}35 \% \text { altered, ol completely } \\
\text { altered to olive-green smectite } \\
\text { and iddingsite. Smectite has } \\
\text { basal } d=13.80 \AA \text { which expands } \\
\text { to } 18.02 \AA \text { after glycol. Only } \\
\text { smectite } \mathrm{A} \text { is present. Mt has } \\
\text { hematite rims. Rock is } \\
\text { glomeroporphyritic. }\end{array}$ & \\
\hline sub-ophitic & $\begin{array}{l}0.02-1.37 \\
0.005-0.50 \\
0.01-0.42 \\
0.005-0.17 \\
0.01-0.50\end{array}$ & $\begin{array}{l}\mathrm{pl} \\
\mathrm{cpx} \\
\text { il } \\
\mathrm{mt} \\
\mathrm{ol}\end{array}$ & $\begin{array}{r}47 \\
40 \\
2 \\
1 \\
<1\end{array}$ & $\begin{array}{l}\text { Equant skeletal timag. and } \\
\text { ilmenite. Pyrite is present. }\end{array}$ & $\begin{array}{l}20 \% \text { altered, ol totally altered } \\
\text { to olive-green smectite and } \\
\text { iddingsite. Smectite has } \\
\text { basal } d=12.99 \AA \text { which expands } \\
\text { to } 17.66 \AA \text { after glycol. Only } \\
\text { smectite A is present. Rock is } \\
\text { glomeroporphyritic. }\end{array}$ & $\mathrm{X}, \mathrm{T}, \mathrm{R} 1, \mathrm{M}$ \\
\hline $\begin{array}{l}\text { microlitic, } \\
\text { intergranular }\end{array}$ & $\begin{array}{r}0.005-0.98 \\
0.001-0.15 \\
<0.001-0.09 \\
0.003-0.50 \\
0.008-0.15\end{array}$ & $\begin{array}{l}\mathrm{pl} \\
\mathrm{cpx} \\
\mathrm{mt} \\
\text { ol } \\
\text { il }\end{array}$ & $\begin{array}{r}48 \\
37 \\
6 \\
4 \\
4\end{array}$ & & $\begin{array}{l}26 \% \text { altered, ol totally altered } \\
\text { to olive-green smectite and } \\
\text { pleochroic iddingsite. Smec- } \\
\text { tite has basal } d=14.97 \AA \text { which } \\
\text { expands to } 17.31 \AA \text { after glycol. } \\
\text { Only smectite A is present. } \\
\text { Vesicles are filled with olive- } \\
\text { green fibrous smectite. }\end{array}$ & \\
\hline $\begin{array}{l}\text { microlitic, } \\
\text { intergranular }\end{array}$ & $\begin{array}{r}0.003-1.30 \\
0.001-0.20 \\
<0.001-0.10 \\
0.008-0.20 \\
0.01-0.50\end{array}$ & $\begin{array}{l}\mathrm{pl} \\
\mathrm{cpx} \\
\mathrm{mt} \\
\text { il } \\
\text { ol }\end{array}$ & $\begin{array}{r}45 \\
40 \\
7 \\
5 \\
<1\end{array}$ & $\begin{array}{l}\text { Titanomagnetite and elon- } \\
\text { gate ilmenite. Timag. is flat } \\
\text { gray in reflecting light indi- } \\
\text { cating low-temp. oxidation. } \\
\text { Pyrite is present. }\end{array}$ & $\begin{array}{l}25 \% \text { altered, ol totally altered } \\
\text { to olive-green smectite and } \\
\text { iddingsite. Smectite has basal } \\
d=13.59 \AA \text { which expands to } \\
17.66 \AA \text { after glycol. Smectite } \\
\text { A and B and chlorite(?) present. } \\
\text { Most vesicles are filled with } \\
\text { fibrous olive-green smectite. } \\
\text { Pl cores replaced by kf. }\end{array}$ & $\mathrm{X}, \mathrm{T}, \mathrm{M}$ \\
\hline $\begin{array}{l}\text { microlitic, } \\
\text { intergranular }\end{array}$ & $\begin{array}{r}0.01-0.95 \\
0.001-0.10 \\
<0.001-0.10 \\
0.003-0.14 \\
0.01-0.50\end{array}$ & $\begin{array}{l}\mathrm{pl} \\
\mathrm{cpx} \\
\mathrm{mt} \\
\text { il } \\
\text { ol }\end{array}$ & $\begin{array}{r}41 \\
38 \\
5 \\
5 \\
3\end{array}$ & $\begin{array}{l}\text { Equant timag. and elon- } \\
\text { gate ilmenite. Olivine } \\
\text { phenocrysts contain } \\
\text { chromite. Pyrite is } \\
\text { present. }\end{array}$ & $\begin{array}{l}17 \% \text { altered, ol totally altered } \\
\text { to olive-green smectite with } \\
\text { iddingsite rims. Smectite has } \\
\text { basal } d=14.48 \AA \text { which splits to } \\
\text { form two peaks, } 14.72 \AA \text { (chlo- } \\
\text { rite?) and } 17.31 \AA \text {, after glycol. } \\
\text { Smectite A and B and chlorite } \\
\text { (?) present. Vesicles filled } \\
\text { with fibrous olive-green smec- } \\
\text { tite. }\end{array}$ & $\mathrm{X}, \mathrm{T}, \mathrm{R} 1, \mathrm{M}$ \\
\hline $\begin{array}{l}\text { microlitic, } \\
\text { intergranular }\end{array}$ & $\begin{array}{r}0.005-0.45 \\
0.001-0.01 \\
<0.001-0.02 \\
0.01-0.50 \\
0.01-0.06\end{array}$ & $\begin{array}{l}\mathrm{pl} \\
\mathrm{cpx} \\
\mathrm{mt} \\
\text { ol } \\
\text { il }\end{array}$ & $\begin{array}{r}45 \\
42 \\
7 \\
2 \\
2\end{array}$ & & $\begin{array}{l}\sim 20 \% \text { altered, ol totally altered } \\
\text { to olive-green fibrous smectite } \\
\text { and iddingsite. Smectite has } \\
\text { basal } d=12.62 \AA \text { which expands } \\
\text { to } 17.31 \AA \text { after glycol. Only } \\
\text { smectite } \mathrm{A} \text { is present. Vesi- } \\
\text { cles are almost all filled with } \\
\text { fibrous olive-green smectite. }\end{array}$ & \\
\hline sub-ophitic & $\begin{array}{ll}0.01 & -0.50 \\
0.02 & -0.75 \\
0.01 & -0.42 \\
0.02 & -0.50 \\
0.003-0.15\end{array}$ & $\begin{array}{l}\mathrm{cpx} \\
\mathrm{pl} \\
\text { il } \\
\text { ol } \\
\mathrm{mt}\end{array}$ & $\begin{array}{r}35 \\
32 \\
2 \\
1 \\
<1\end{array}$ & & $\begin{array}{l}46 \% \text { altered, ol about half re- } \\
\text { placed by yellow to brown } \\
\text { smectite with iddingsite rims. } \\
\text { Smectite has basal } d=14.72 \AA \\
\text { (chlorite?) and } 16.35 \AA \text { which } \\
\text { shift to } 14.72 \AA \text { and } 16.66 \AA \\
\text { after glycol. Smectite A and } \\
\text { B and chlorite(?) present. }\end{array}$ & \\
\hline
\end{tabular}


R. J. KIRKPATRICK, D, A. CLAGUE, W. FREISEN

APPENDIX - Continued

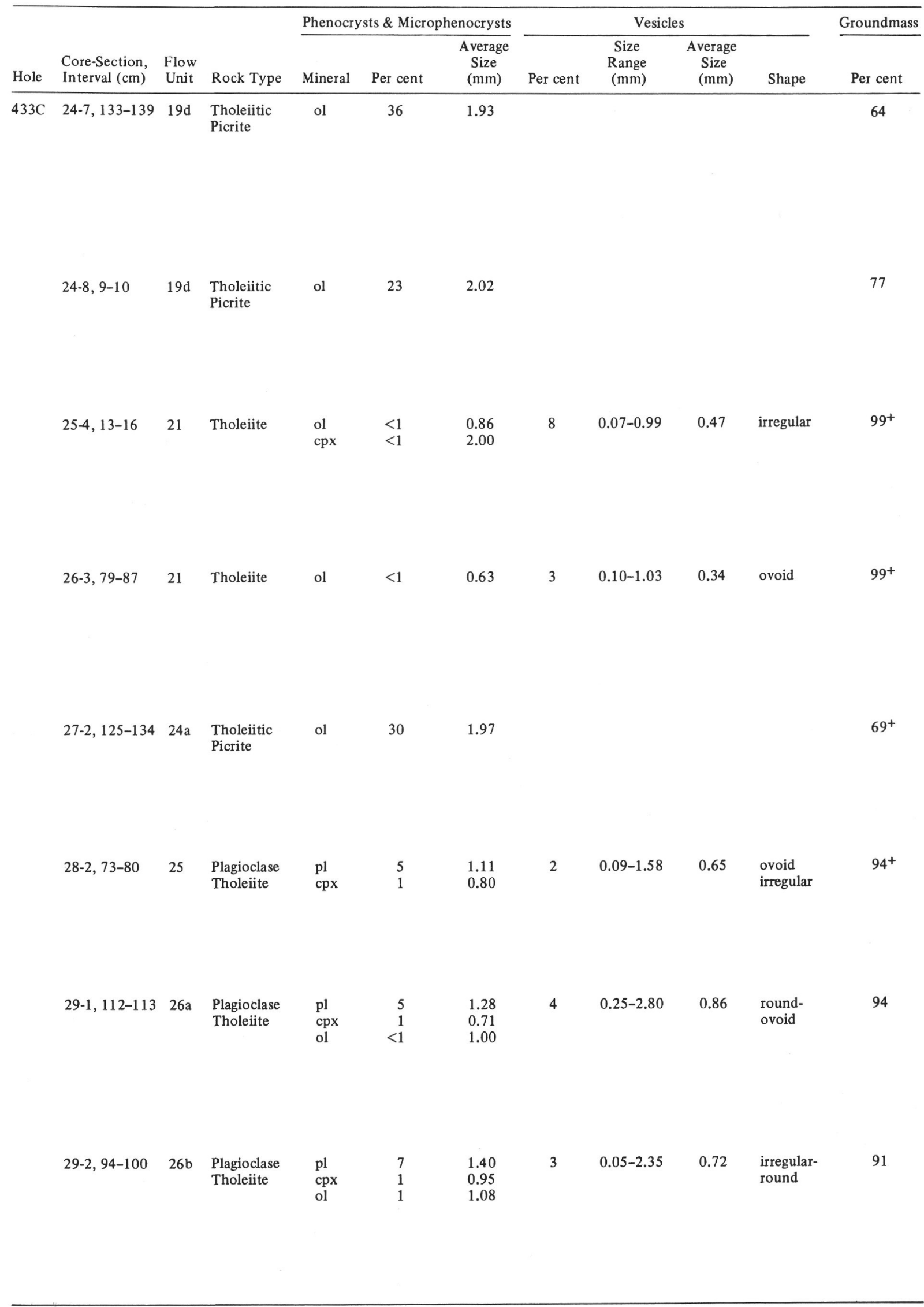


APPENDIX - Continued

\begin{tabular}{|c|c|c|c|c|c|c|}
\hline \multicolumn{5}{|c|}{ Groundmass } & \multirow[b]{2}{*}{ Alteration and Remarks b } & \multirow[b]{2}{*}{ Other Work } \\
\hline $\begin{array}{l}\text { Dominant } \\
\text { Texture }\end{array}$ & $\begin{array}{l}\text { Size Range } \\
(\mathrm{mm})\end{array}$ & Minerals ${ }^{\mathrm{a}}$ & Per cent & Opaque Minerals & & \\
\hline sub-ophitic & $\begin{array}{ll}0.02 & -1.00 \\
0.01 & -0.50 \\
0.01 & -0.40\end{array}$ & $\begin{array}{l}\mathrm{pl} \\
\mathrm{cpx} \\
\text { il }\end{array}$ & $\begin{array}{r}36 \\
25 \\
3\end{array}$ & $\begin{array}{l}\text { Equant timag. and elon- } \\
\text { gate ilmenite. Olivine } \\
\text { phenocrysts contain } \\
\text { chromite. Pyrite is present. }\end{array}$ & $\begin{array}{l}37 \% \text { altered, ol about } 20-25 \% \\
\text { replaced by yellow smectite } \\
\text { and rimmed by iddingsite. } \\
\text { Smectite has basal } d=14.72 \AA \\
\text { which splits to a } 14.72 \AA \text { and a } \\
16.35 \AA \text { peak after glycol. } \\
\text { Smectite } \mathrm{A}, \mathrm{B} \text {, and chlorite } \\
\text { are present. Mt partly replaced } \\
\text { by hematite. Zeolites(?) pres- } \\
\text { ent. Rare ol are kink-banded. }\end{array}$ & $\mathrm{X}, \mathrm{T}, \mathrm{M}$ \\
\hline intergranular & $\begin{array}{l}0.01-1.00 \\
0.01-0.40 \\
0.15-0.50 \\
0.005-0.50\end{array}$ & $\begin{array}{l}\text { pl } \\
\text { cpx } \\
\text { ol } \\
\text { il }\end{array}$ & $\begin{array}{r}39 \\
25 \\
11 \\
2\end{array}$ & & $\begin{array}{l}38 \% \text { altered, ol } 10 \% \text { replaced } \\
\text { by bright blue-green and pale } \\
\text { yellow-buff smectite. Smectite } \\
\text { has basal } d=15.49 \AA \text { which ex- } \\
\text { pands by } 17.66 \AA \text { after glycol. } \\
\text { Smectite } B, \text { chlorite and phillip- } \\
\text { site are present. Rare ol are } \\
\text { kink-banded. }\end{array}$ & \\
\hline $\begin{array}{l}\text { microlitic, } \\
\text { intergranular }\end{array}$ & $\begin{array}{r}0.01-0.66 \\
<0.001-0.15 \\
<0.001-0.15 \\
0.01-0.50 \\
0.005-0.19\end{array}$ & $\begin{array}{l}\mathrm{pl} \\
\mathrm{cpx} \\
\mathrm{mt} \\
\text { ol } \\
\text { il }\end{array}$ & $\begin{array}{r}50 \\
37 \\
7 \\
5 \\
1\end{array}$ & & $\begin{array}{l}18 \% \text { altered, ol almost totally } \\
\text { replaced by buff smectite and } \\
\text { iddingsite rims. Smectite has } \\
\text { basal } d=13.59 \AA \text { which expands } \\
\text { to } 17.66 \AA \text { after glycol. Only } \\
\text { smectite A is present. Vesicles } \\
\text { filled with yellow to yellow- } \\
\text { green fibrous smectite. Pl } \\
\text { cores partly replaced by K-spar. }\end{array}$ & \\
\hline intergranular & $\begin{array}{l}0.001-1.05 \\
0.001-0.30 \\
0.001-0.05 \\
0.01-0.50 \\
0.005-0.10\end{array}$ & $\begin{array}{l}\mathrm{pl} \\
\mathrm{cpx} \\
\mathrm{mt} \\
\text { ol } \\
\text { il }\end{array}$ & $\begin{array}{r}45 \\
42 \\
6 \\
5 \\
1\end{array}$ & & $\begin{array}{l}\sim 12 \% \text { altered, ol totally re- } \\
\text { placed by olive-green fibrous } \\
\text { smectite and rimmed by idding- } \\
\text { site. Smectite has basal } d= \\
13.59 \AA \text { which expands to } \\
18.39 \AA \text { after glycol. Smec- } \\
\text { tite A is present. Vesicles } \\
\text { filled with olive-green fibrous } \\
\text { smectite. }\end{array}$ & \\
\hline sub-ophitic & $\begin{array}{r}0.005-1.20 \\
0.01-0.50 \\
0.01-0.50 \\
<0.001-0.05\end{array}$ & $\begin{array}{l}\mathrm{pl} \\
\mathrm{cpx} \\
\mathrm{ol} \\
\mathrm{mt}\end{array}$ & $\begin{array}{r}28 \\
26 \\
12 \\
3\end{array}$ & & $\begin{array}{l}\sim 59 \% \text { altered, ol partly altered } \\
\text { to fibrous buff smectite and } \\
\text { iddingsite. Smectite has basal } \\
d=14.97 \AA \text { which splits to a } \\
14.72 \AA \text { and a } 17.66 \AA \text { peak } \\
\text { after glycol. Smectite B and } \\
\text { chlorite present. Calcite in } \\
\text { vein. }\end{array}$ & \\
\hline intergranular & $\begin{array}{l}0.005-1.00 \\
0.005-0.30 \\
0.01-0.20 \\
0.003-0.20\end{array}$ & $\begin{array}{l}\mathrm{pl} \\
\mathrm{cpx} \\
\text { il } \\
\mathrm{mt}\end{array}$ & $\begin{array}{r}47 \\
45 \\
2 \\
<1\end{array}$ & $\begin{array}{l}\text { Equant timag. and rare } \\
\text { elongate ilmenite. }\end{array}$ & $\begin{array}{l}\sim 3 \% \text { altered, smectite has } \\
\text { basal } d=13.80 \AA \text { which ex- } \\
\text { pands to } 17.66 \AA \text { after glycol. } \\
\text { Smectite } \mathrm{A} \text { is present. Rare } \\
\text { phillipsite(?) also present. } \\
\text { Vesicles are filled with brown } \\
\text { smectite with green smectite } \\
\text { at the center. }\end{array}$ & $\begin{array}{l}\mathrm{X}, \mathrm{P}, \mathrm{R} 1, \mathrm{~S} \\
\mathrm{~K}, \mathrm{M}\end{array}$ \\
\hline in tergranular & $\begin{array}{l}0.005-0.80 \\
0.001-0.50 \\
0.01-0.37 \\
0.005-0.10 \\
0.01-0.50\end{array}$ & $\begin{array}{l}\mathrm{pl} \\
\mathrm{cpx} \\
\text { il } \\
\mathrm{mt} \\
\mathrm{ol}\end{array}$ & $\begin{array}{r}45 \\
40 \\
5 \\
2 \\
2\end{array}$ & $\begin{array}{l}\text { Elongate ilmenite. Pyrite } \\
\text { is present. }\end{array}$ & $\begin{array}{l}13 \% \text { altered, ol completely } \\
\text { altered to olive-green fibrous } \\
\text { smectite and iddingsite. Smec- } \\
\text { tite has basal } d=13.80 \AA \text { which } \\
\text { expands to } 17.31 \AA \text { after glycol. } \\
\text { Smectite A is present. P1 cores } \\
\text { partly replaced by K-spar. Vesi- } \\
\text { cles have thin lining of olive- } \\
\text { green fibrous smectite. }\end{array}$ & $\mathrm{X}, \mathrm{T}, \mathrm{R} 1, \mathrm{M}$ \\
\hline intergranular & $\begin{array}{r}0.005-1.66 \\
<0.001-0.50 \\
<0.001-0.05 \\
0.01-0.05 \\
0.01-0.50\end{array}$ & $\begin{array}{l}\text { ol } \\
\text { cpx } \\
\text { mt } \\
\text { il } \\
\text { ol }\end{array}$ & $\begin{array}{r}46 \\
39 \\
3 \\
2 \\
1\end{array}$ & $\begin{array}{l}\text { Tiny exsolved timag. and } \\
\text { ilmenite. Olivine phenocrysts } \\
\text { enclose chromite. Pyrite is } \\
\text { present. }\end{array}$ & $\begin{array}{l}14 \% \text { altered, ol totally altered } \\
\text { to fibrous olive-green smectite } \\
\text { with iddingsite rims. Smectite } \\
\text { has basal } d=12.80 \AA \text { which ex- } \\
\text { pands to } 17.31 \AA \text { after glycol. } \\
\text { Celadonite }(d=10.04 \AA) \text {, smec- } \\
\text { tite A, rare alkali fel-spar and } \\
\text { zeolites are present. Vesicles } \\
\text { filled with yellow-green } \\
\text { celadonite. }\end{array}$ & $\begin{array}{l}X, T, R 1, S \\
K, M\end{array}$ \\
\hline
\end{tabular}


APPENDIX - Continued

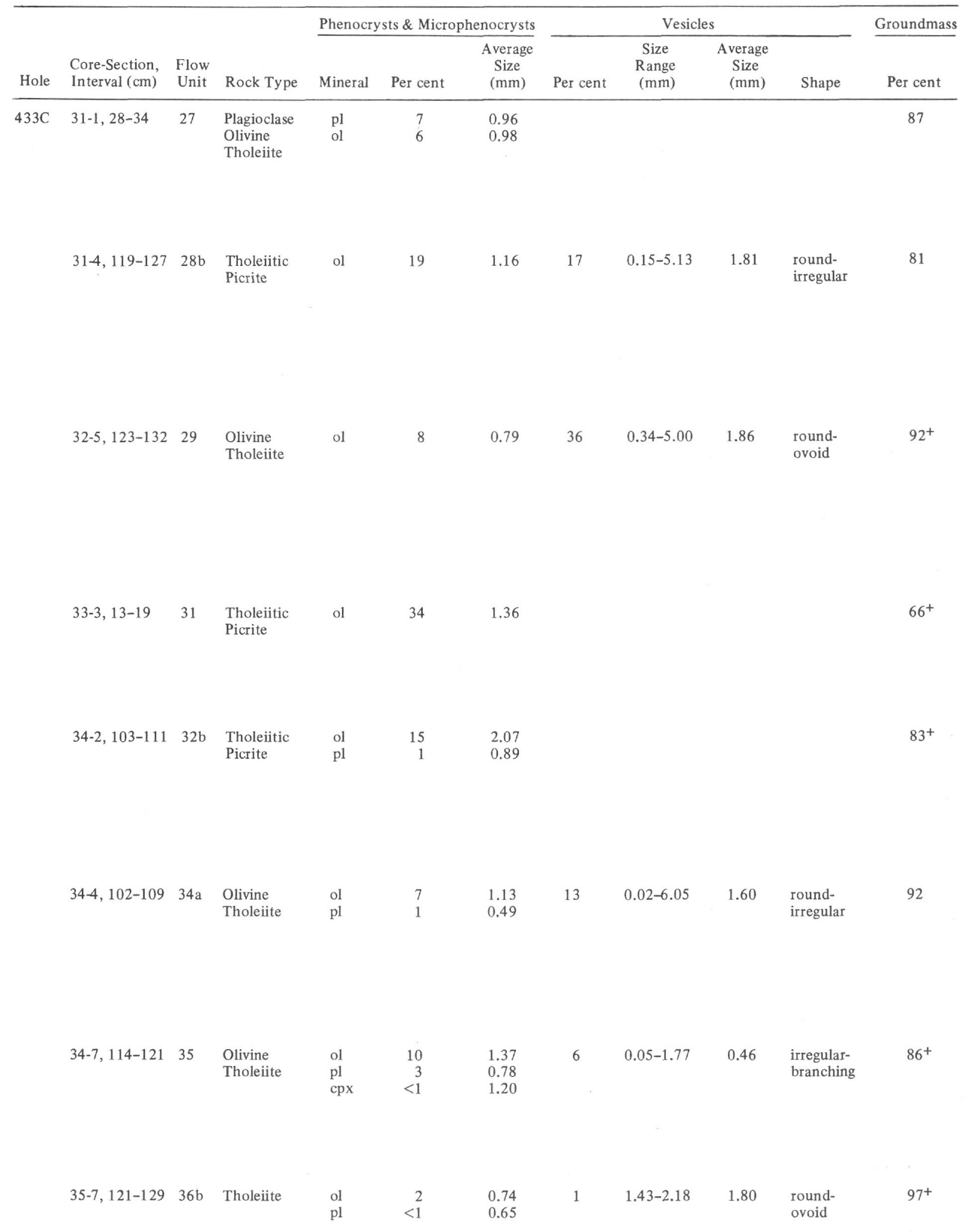


APPENDIX - Continued

\begin{tabular}{|c|c|c|c|c|c|c|}
\hline \multicolumn{5}{|c|}{ Groundmass } & \multirow[b]{2}{*}{ Alteration and Remarks b } & \multirow[b]{2}{*}{ Other Work } \\
\hline $\begin{array}{l}\text { Dominant } \\
\text { Texture }\end{array}$ & $\begin{array}{l}\text { Size Range } \\
(\mathrm{mm})\end{array}$ & Mineralsa & Per cent & Opaque Minerals & & \\
\hline intergranular & $\begin{array}{r}0.005-1.05 \\
<0.001-0.23 \\
0.005-0.19 \\
0.01-0.20 \\
0.01-0.50\end{array}$ & $\begin{array}{l}\mathrm{pl} \\
\mathrm{cpx} \\
\mathrm{mt} \\
\mathrm{il} \\
\mathrm{ol}\end{array}$ & $\begin{array}{r}40 \\
37 \\
5 \\
3 \\
2\end{array}$ & $\begin{array}{l}\text { Equant timag. and rare } \\
\text { elongate ilmenite. Chromite } \\
\text { and pyrite are present but } \\
\text { rare. }\end{array}$ & $\begin{array}{l}5 \% \text { altered, ol } 10-15 \% \text { replaced } \\
\text { by buff smectite. Smectite has } \\
\text { basal } d=14.72 \AA \text { and } 14.97 \AA \\
\text { which shift to } 14.72 \AA \text { and } \\
17.31 \AA \text { after glycol. Chlorite(?) } \\
\text { and smectite B are present. } \\
\text { Some ol poikilitically encloses } \\
\text { pl. }\end{array}$ & $\begin{array}{l}\mathrm{X}, \mathrm{P}, \mathrm{R} 1, \mathrm{~S}, \\
\mathrm{~K}, \mathrm{M}\end{array}$ \\
\hline sub-ophitic & $\begin{array}{l}0.005-1.55 \\
0.001-0.30 \\
0.01-0.50 \\
0.005-0.10 \\
0.01-0.19\end{array}$ & $\begin{array}{l}\mathrm{pl} \\
\mathrm{cpx} \\
\text { ol } \\
\mathrm{mt} \\
\text { il }\end{array}$ & $\begin{array}{r}41 \\
22 \\
10 \\
6 \\
2\end{array}$ & & $\begin{array}{l}\sim 78 \% \text { altered, ol totally re- } \\
\text { placed by fibrous yellow smec- } \\
\text { tite and iddingsite. Pl about } \\
80 \% \text { replaced by pale olive- } \\
\text { green smectite. Smectite has } \\
\text { basal } d=14.72 \AA \text { which expands } \\
\text { to } 16.98 \AA \text { after glycol. Cal- } \\
\text { cite, chlorite(?), and smectite } \\
\text { B present. Vesicles filled with } \\
\text { calcite and fibrous smectite. }\end{array}$ & \\
\hline sub-ophitic & $\begin{array}{l}0.01-0.75 \\
0.001-0.25 \\
0.005-0.50 \\
0.005-0.15 \\
0.008-0.25\end{array}$ & $\begin{array}{l}\text { pl } \\
\mathrm{cpx} \\
\text { ol } \\
\mathrm{mt} \\
\text { il }\end{array}$ & $\begin{array}{r}17 \\
29 \\
11 \\
3 \\
3\end{array}$ & & $\begin{array}{l}67 \% \text { altered, ol totally replaced } \\
\text { by fibrous olive-green smectite } \\
\text { and iddingsite. Pl about } 70 \% \\
\text { replaced by green smectite in } \\
\text { cores. Smectite has basal } d= \\
14.02 \AA \text { which expands to } \\
17.31 \AA \text { after glycol. Smectite } \\
\text { A and B and chlorite(?) present. } \\
\text { Vesicles filled with fibrous } \\
\text { olive-green smectite. }\end{array}$ & \\
\hline ophitic & $\begin{array}{ll}0.01 & -0.91 \\
0.01 & -0.50 \\
0.01 & -0.50 \\
0.01 & -0.35 \\
0.005-0.15\end{array}$ & $\begin{array}{l}\text { pl } \\
\mathrm{cpx} \\
\text { ol } \\
\text { il } \\
\mathrm{mt}\end{array}$ & $\begin{array}{r}30 \\
27 \\
5 \\
3 \\
2\end{array}$ & & $\begin{array}{l}38 \% \text { altered, ol about half re- } \\
\text { placed by pale yellow smectite } \\
\text { and iddingsite. Smectite has } \\
\text { basal } d=14.72 \AA \text { and } 16.15 \AA \\
\text { which shift to } 14.72 \AA \text { and } \\
16.98 \AA \text { after gly col. Chlorite(?) } \\
\text { and smectite B present. }\end{array}$ & \\
\hline ophitic & $\begin{array}{l}0.02-1.00 \\
0.02-0.50 \\
0.01-0.50 \\
0.01-0.35 \\
0.003-0.15\end{array}$ & $\begin{array}{l}\text { pl } \\
\text { cpx } \\
\text { ol } \\
\text { il } \\
\text { mt }\end{array}$ & $\begin{array}{r}47 \\
26 \\
5 \\
4 \\
1\end{array}$ & $\begin{array}{l}\text { Equant exsolved timag. and } \\
\text { elongate ilmenite. Olivine } \\
\text { phenocrysts contain } \\
\text { chromite. Pyrite is } \\
\text { present. }\end{array}$ & $\begin{array}{l}36 \% \text { altered, ol totally altered } \\
\text { to smectite and iddingsite. } \\
\text { Smectite has basal } d=14.24 \AA \\
\text { and } 15.22 \AA \text { which shift to } \\
17.31 \AA \text { after glycol. Smectite } \\
\text { A, B, chlorite, hematite, and } \\
\text { goethite present. Some cpx } \\
\text { replaced by yellow-brown } \\
\text { amphibole(?). }\end{array}$ & $\mathrm{X}, \mathrm{T}, \mathrm{M}$ \\
\hline intergranular & $\begin{array}{c}<0.001-0.005 \\
0.005-0.84 \\
0.008-0.25 \\
0.01-0.50 \\
<0.001-0.10\end{array}$ & $\begin{array}{l}\mathrm{cpx} \\
\mathrm{pl} \\
\text { il } \\
\mathrm{ol} \\
\mathrm{mt}\end{array}$ & $\begin{array}{c}40-50 \\
35-40 \\
7-8 \\
5-7 \\
2-3\end{array}$ & & $\begin{array}{l}\sim 22 \% \text { altered, ol totally re- } \\
\text { placed by pale-green to buff } \\
\text { smectite and iddingsite. Pl } \\
\text { cores replaced by pale smectite. } \\
\text { Smectite has basal } d=12.80 \AA \\
\text { which expands to } 17.31 \AA \\
\text { after glycol. Calcite, phillipsite, } \\
\text { amphibole, and smectite A are } \\
\text { present. }\end{array}$ & \\
\hline intergranular & $\begin{array}{r}0.01-0.90 \\
<0.001-0.20 \\
0.001-0.15 \\
0.01-0.50 \\
0.005-0.20\end{array}$ & $\begin{array}{l}\mathrm{pl} \\
\mathrm{cpx} \\
\mathrm{mt} \\
\text { ol } \\
\text { il }\end{array}$ & $\begin{array}{r}44 \\
36 \\
4 \\
2 \\
<1\end{array}$ & $\begin{array}{l}\text { Tiny equant exsolved timag. } \\
\text { and elongate ilmenite. } \\
\text { Olivine phenocrysts con- } \\
\text { tain chromite that is zoned } \\
\text { to chrome-rich timag. } \\
\text { Pyrite is present. }\end{array}$ & $\begin{array}{l}23 \% \text { altered. Ol totally re- } \\
\text { placed by smectite and } \\
\text { iddingsite. Smectite has basal } \\
d=12.80 \AA \text { which expands to } \\
17.31 \AA \text { after glycol. Vesicles } \\
\text { filled with fibrous pale olive- } \\
\text { green smectite. Smectite A } \\
\text { and rare carbonate present. }\end{array}$ & $\mathrm{X}, \mathrm{T}, \mathrm{R} 1, \mathrm{M}$ \\
\hline sub-ophitic & $\begin{array}{ll}0.05 & -1.20 \\
0.05 & -0.50 \\
0.03 & -0.50 \\
0.03 & -0.55 \\
0.01 & -0.15\end{array}$ & $\begin{array}{l}\mathrm{pl} \\
\mathrm{cpx} \\
\text { ol } \\
\text { il } \\
\mathrm{mt}\end{array}$ & $\begin{array}{r}47 \\
36 \\
7 \\
5 \\
1\end{array}$ & & $\begin{array}{l}37 \% \text { altered. Ol completely } \\
\text { altered to fibrous olive-green } \\
\text { smectite and iddingsite. Smec- } \\
\text { tite has basal } d=12.44 \AA \text { which } \\
\text { expands to } 17.31 \AA \text { after glycol. } \\
\text { Vesicles are filled with yellow- } \\
\text { green to olive-green smectite. } \\
\text { Smectite A is present. }\end{array}$ & \\
\hline
\end{tabular}




\section{R. J. KIRKPATRICK, D. A. CLAGUE, W. FREISEN}

APPENDIX - Continued

\begin{tabular}{|c|c|c|c|c|c|c|c|c|c|c|c|}
\hline \multirow[b]{2}{*}{ Hole } & \multirow[b]{2}{*}{$\begin{array}{l}\text { Core-Section, } \\
\text { Interval }(\mathrm{cm})\end{array}$} & \multirow[b]{2}{*}{$\begin{array}{l}\text { Flow } \\
\text { Unit }\end{array}$} & \multirow[b]{2}{*}{ Rock Type } & \multicolumn{3}{|c|}{ Phenocrysts \& Microphenocrysts } & \multicolumn{4}{|c|}{ Vesicles } & \multirow{2}{*}{$\begin{array}{l}\text { Groundmass } \\
\text { Per cent }\end{array}$} \\
\hline & & & & Mineral & Per cent & $\begin{array}{l}\text { Average } \\
\text { Size } \\
(\mathrm{mm})\end{array}$ & Per cent & $\begin{array}{c}\text { Size } \\
\text { Range } \\
(\mathrm{mm})\end{array}$ & $\begin{array}{c}\text { Average } \\
\text { Size } \\
(\mathrm{mm})\end{array}$ & Shape & \\
\hline $433 \mathrm{C}$ & $36-4,138-148$ & 40 & $\begin{array}{l}\text { Olivine } \\
\text { Tholeiite }\end{array}$ & ol & 7 & 1.24 & 9 & $0.65-5.23$ & 2.03 & $\begin{array}{l}\text { round- } \\
\text { irregular }\end{array}$ & 93 \\
\hline
\end{tabular}

$\begin{array}{llllll}37-3,79-87 & 44 & \text { Tholeiite } & \text { ol } & 2 & 0.75\end{array}$

$38-1,67-76$

\begin{tabular}{|c|c|c|c|c|c|}
\hline $41-1,40-49$ & $51 \mathrm{~b}$ & Tholeiite & $\begin{array}{l}\text { pl } \\
\text { cpx }\end{array}$ & $\begin{array}{l}2 \\
1\end{array}$ & $\begin{array}{l}0.84 \\
0.60\end{array}$ \\
\hline $41-4,51-58$ & $51 \mathrm{~b}$ & Tholeiite & pl & 1 & 1.04 \\
\hline $42-1,56-63$ & 52 & Tholeiite & $\begin{array}{l}\text { ol } \\
\text { pl } \\
\mathrm{cpx}\end{array}$ & $\begin{array}{r}1 \\
<1 \\
<1\end{array}$ & $\begin{array}{l}0.78 \\
1.16 \\
0.67\end{array}$ \\
\hline
\end{tabular}


APPENDIX - Continued

\begin{tabular}{|c|c|c|c|c|c|c|}
\hline \multicolumn{5}{|c|}{ Groundmass } & \multirow[b]{2}{*}{ Alteration and Remarks b } & \multirow[b]{2}{*}{ Other Work } \\
\hline $\begin{array}{l}\text { Dominant } \\
\text { Texture }\end{array}$ & $\begin{array}{l}\text { Size Range } \\
(\mathrm{mm})\end{array}$ & Minerals ${ }^{a}$ & Per cent & Opaque Minerals & & \\
\hline sub-ophitic & $\begin{array}{ll}0.01 & -0.85 \\
0.01 & -0.41 \\
0.01 & -0.50 \\
& - \\
& -\end{array}$ & $\begin{array}{l}\text { pl } \\
\text { cpx } \\
\text { ol } \\
\text { mt } \\
\text { il }\end{array}$ & $\begin{array}{r}45 \\
38 \\
4 \\
3 \\
3\end{array}$ & & $\begin{array}{l}45 \% \text { altered. Ol to tally re- } \\
\text { placed by fibrous yellow-green } \\
\text { smectite with iddingsite rims. } \\
\text { Smectite has basal } d=12.80 \AA \\
\text { which expands to } 17.31 \AA \\
\text { after gly col. Vesicles are lined } \\
\text { or filled with fibrous celadonite } \\
(d=9.93 \AA) \text { and smectite. Rare } \\
\text { amphibole(?) replacing cpx. } \\
\text { Smectite A only. }\end{array}$ & \\
\hline sub-ophitic & $\begin{array}{ll}0.03 & -1.35 \\
0.02 & -0.50 \\
0.05 & -0.50 \\
0.05 & -0.50 \\
0.01 & -0.34\end{array}$ & $\begin{array}{l}\mathrm{pl} \\
\mathrm{cpx} \\
\text { ol } \\
\text { il } \\
\mathrm{mt}\end{array}$ & $\begin{array}{r}57 \\
32 \\
4 \\
4 \\
1\end{array}$ & $\begin{array}{l}\text { Equant to skeletal timag. } \\
\text { and elongate ilmenite. } \\
\text { Olivine phenocrysts } \\
\text { contain chromite. }\end{array}$ & $\begin{array}{l}18 \% \text { altered. Ol totally re- } \\
\text { placed by fibrous olive green } \\
\text { smectite and iddingsite. Smec- } \\
\text { tite has basal } d=14.24 \AA \text { which } \\
\text { expands to } 17.31 \AA \text { after glycol. } \\
\text { Smectite } A, B \text {, and chlorite(?) } \\
\text { present. }\end{array}$ & $\mathrm{X}, \mathrm{T}, \mathrm{M}$ \\
\hline ophitic & $\begin{array}{ll}0.01 & -0.65 \\
0.01 & -0.50 \\
0.01 & -0.50 \\
0.01 & -0.42 \\
0.001-0.12\end{array}$ & $\begin{array}{l}\mathrm{pl} \\
\mathrm{cpx} \\
\text { ol } \\
\text { il } \\
\mathrm{mt}\end{array}$ & $\begin{array}{r}50 \\
33 \\
5 \\
3 \\
1\end{array}$ & $\begin{array}{l}\text { Elongate ilmenite. Olivine } \\
\text { phenocrysts contain } \\
\text { chromite that is zoned } \\
\text { to chrome-rich timag. } \\
\text { Pyrite is present. }\end{array}$ & $\begin{array}{l}31 \% \text { altered. Ol about } 20 \% \\
\text { altered to pale yellow fibrous } \\
\text { smectite with fibrous yellow- } \\
\text { deep green and bright blue- } \\
\text { green (pleochroic) smectite } \\
\text { along fractures and rims. Smec- } \\
\text { tite has basal } d=14.72 \AA \text { which } \\
\text { splits to form a } 14.72 \AA \text { and a } \\
17.66 \AA \text { peak after gly col. } \\
\text { Chlorite(?), smectite } B \text {, and } \\
\text { phillipsite are present. }\end{array}$ & $\mathrm{X}, \mathrm{T}, \mathrm{M}$ \\
\hline ophitic & $\begin{array}{ll}0.01 & -1.35 \\
0.01 & -0.50 \\
0.01 & -0.50 \\
0.01 & -0.45\end{array}$ & $\begin{array}{l}\text { pl } \\
\text { cpx } \\
\text { ol } \\
\text { il }\end{array}$ & $\begin{array}{r}54 \\
31 \\
10 \\
5\end{array}$ & & $\begin{array}{l}37 \% \text { altered. Ol totally replaced } \\
\text { by fibrous buff-green smectite } \\
\text { and iddingsite. Smectite has } \\
\text { basal } d=14.48 \AA \text { which expands } \\
\text { to } 16.66 \AA \text { after glycol. Smec- } \\
\text { tite } \mathrm{A}, \mathrm{B} \text {, and chlorite(?) } \\
\text { present. }\end{array}$ & \\
\hline intergranular & $\begin{array}{l}0.02-0.50 \\
0.005-0.50 \\
0.005-0.50 \\
0.01-0.35 \\
0.003-0.19\end{array}$ & $\begin{array}{l}\text { pl } \\
\text { cpx } \\
\text { ol } \\
\text { il } \\
\text { mt }\end{array}$ & $\begin{array}{r}47 \\
37 \\
8 \\
2 \\
1\end{array}$ & $\begin{array}{l}\text { Elongate ilmenite. Olivine } \\
\text { phenocrysts contain } \\
\text { chromite that is zoned } \\
\text { to chrome-rich timag. } \\
\text { Some ilmenites are } \\
\text { exsolved. }\end{array}$ & $\begin{array}{l}18 \% \text { altered. Ol about } 80 \% \\
\text { altered to smectite, chlorite, } \\
\text { and iddingsite. Smectite has } \\
\text { basal } d=14.78 \AA \text { and } 14.98 \AA \\
\text { which shift to } 14.72 \AA \text { and } \\
17.31 \AA \text { after glycol. Smectite } \\
\text { B and chlorite present. }\end{array}$ & $\mathrm{X}, \mathrm{T}, \mathrm{R} 1, \mathrm{M}$ \\
\hline intergranular & $\begin{array}{l}0.01-0.45 \\
0.001-0.25 \\
0.05-0.50 \\
0.005-0.25 \\
0.001-0.20\end{array}$ & $\begin{array}{l}\text { pl } \\
\mathrm{cpx} \\
\text { ol } \\
\text { il } \\
\mathrm{mt}\end{array}$ & $\begin{array}{r}41 \\
38 \\
8 \\
3 \\
2\end{array}$ & $\begin{array}{l}\text { Elongate ilmenite; many } \\
\text { are mottled because of a } \\
\text { combination of high- and } \\
\text { low-temp. oxidation. } \\
\text { Olivine phenocrysts con- } \\
\text { tain chromite. Nearly pure } \\
\text { magnetite pyrite, and chal- } \\
\text { copyrite are present. }\end{array}$ & $\begin{array}{l}19 \% \text { altered, ol about } 30 \% \\
\text { altered to smectite, chlorite, } \\
\text { and iddingsite. Smectite has } \\
\text { basal } d=14.78 \AA \text { and } 14.98 \AA \\
\text { which shifts to } 14.72 \AA \text { and } \\
16.66 \AA \text { after glycol. Smectite } \\
\text { B and chlorite present. }\end{array}$ & $\mathrm{X}, \mathrm{P}, \mathrm{T}, \mathrm{R} 1, \mathrm{M}$ \\
\hline intergranular & $\begin{array}{l}0.01-1.65 \\
0.01-0.50 \\
0.008-0.15 \\
0.01-0.70 \\
0.05-0.50\end{array}$ & $\begin{array}{l}\text { pl } \\
\mathrm{cpx} \\
\mathrm{mt} \\
\text { il } \\
\text { ol }\end{array}$ & $\begin{array}{r}50 \\
40 \\
3 \\
3 \\
1\end{array}$ & & $\begin{array}{l}23 \% \text { altered. Smectite has } \\
\text { basal } d=12.27 \AA \text { which ex- } \\
\text { pands to } 17.31 \AA \text { after glycol. } \\
\text { Smectite A only. Hematite } \\
\text { after some mt. }\end{array}$ & \\
\hline intergranular & $\begin{array}{l}0.01-1.25 \\
0.01-0.50 \\
0.01-0.40 \\
0.005-0.15 \\
0.05-0.50\end{array}$ & $\begin{array}{l}\mathrm{pl} \\
\mathrm{cpx} \\
\text { il } \\
\mathrm{mt} \\
\mathrm{ol}\end{array}$ & $\begin{array}{r}60 \\
29 \\
6 \\
3 \\
1\end{array}$ & & $\begin{array}{l}31 \% \text { altered. Smectite has } \\
\text { basal } d=12.62 \AA \text { which ex- } \\
\text { pands to } 17.31 \AA \text { after glycol. } \\
\text { Smectite A only. Hematite } \\
\text { after some mt. }\end{array}$ & \\
\hline intergranular & $\begin{array}{ll}0.01 & -1.85 \\
0.01 & -0.50 \\
0.01 & -0.67 \\
0.05 & -0.50 \\
0.005 & -0.30\end{array}$ & $\begin{array}{l}\text { pl } \\
\text { cpx } \\
\text { il } \\
\text { ol } \\
\text { mt }\end{array}$ & $\begin{array}{r}53 \\
37 \\
4 \\
3 \\
2\end{array}$ & $\begin{array}{l}\text { Equant exsolved timag. and } \\
\text { elongate ilmenite. Pyrite } \\
\text { is present. }\end{array}$ & $\begin{array}{l}\sim 23 \% \text { altered. O1 totally } \\
\text { altered to bright blue-green } \\
\text { fibrous smectite and idding- } \\
\text { site. Smectite has basal } d= \\
12.62 \AA \text { which expands to } \\
17.31 \AA \text { after glycol. Smec- } \\
\text { tite A only. Rare amphibole(?) } \\
\text { after clinopyroxene. }\end{array}$ & $\mathrm{S}, \mathrm{T}, \mathrm{R} 1, \mathrm{M}$ \\
\hline
\end{tabular}




\section{R. J. KIRKPATRICK, D. A. CLAGUE, W. FREISEN}

APPENDIX - Continued

\begin{tabular}{|c|c|c|c|c|c|c|c|c|c|c|c|}
\hline \multirow[b]{2}{*}{ Hole } & \multirow[b]{2}{*}{$\begin{array}{l}\text { Core-Section, } \\
\text { Interval }(\mathrm{cm})\end{array}$} & \multirow[b]{2}{*}{$\begin{array}{l}\text { Flow } \\
\text { Unit }\end{array}$} & \multirow[b]{2}{*}{ Rock Type } & \multicolumn{3}{|c|}{ Phenocrysts \& Microphenocrysts } & \multicolumn{4}{|c|}{ Vesicles } & \multirow{2}{*}{$\begin{array}{l}\text { Groundmass } \\
\text { Per cent }\end{array}$} \\
\hline & & & & Mineral & Per cent & $\begin{array}{l}\text { Average } \\
\text { Size } \\
(\mathrm{mm})\end{array}$ & Per cent & $\begin{array}{c}\text { Size } \\
\text { Range } \\
(\mathrm{mm})\end{array}$ & $\begin{array}{c}\text { Average } \\
\text { Size } \\
(\mathrm{mm})\end{array}$ & Shape & \\
\hline & $42-3,11-20$ & 53 & $\begin{array}{l}\text { Plagioclase } \\
\text { Tholeiite }\end{array}$ & $\begin{array}{l}\mathrm{pl} \\
\mathrm{cpx} \\
\mathrm{ol}\end{array}$ & $\begin{array}{r}17 \\
4 \\
1\end{array}$ & $\begin{array}{l}1.61 \\
1.25 \\
0.85\end{array}$ & & & & & $77^{+}$ \\
\hline & $42-5,85-90$ & 54 & $\begin{array}{l}\text { Plagioclase } \\
\text { Tholeiite }\end{array}$ & $\begin{array}{l}\text { pl } \\
\text { ol } \\
\text { cpx }\end{array}$ & $\begin{array}{r}14 \\
1 \\
1\end{array}$ & $\begin{array}{l}1.89 \\
1.04 \\
1.34\end{array}$ & & & & & 84 \\
\hline $433 \mathrm{C}$ & $44-1,31-35$ & 56 & $\begin{array}{l}\text { Olivine } \\
\text { Tholeiite }\end{array}$ & $\begin{array}{l}\text { ol } \\
\text { pl } \\
\text { cpx }\end{array}$ & $\begin{array}{r}7 \\
<1 \\
<1\end{array}$ & $\begin{array}{l}0.85 \\
0.74 \\
0.48\end{array}$ & & & & & 92 \\
\hline & $44-4,74-81$ & 58 & Tholeiite & $\begin{array}{l}\mathrm{pl} \\
\mathrm{cpx}\end{array}$ & $\begin{array}{l}1 \\
1\end{array}$ & $\begin{array}{l}0.85 \\
0.78\end{array}$ & 1 & $0.35-1.41$ & 1.11 & round & $97^{+}$ \\
\hline & $45-2,26-33$ & $59 \mathrm{c}$ & Tholeiite & $\begin{array}{l}\mathrm{pl} \\
\mathrm{cpx}\end{array}$ & $\begin{array}{l}2 \\
1\end{array}$ & $\begin{array}{l}0.84 \\
0.73\end{array}$ & & & & & 97 \\
\hline & $45-5,96-104$ & 60 & $\begin{array}{l}\text { Plagioclase } \\
\text { Tholeiite }\end{array}$ & $\begin{array}{l}\mathrm{pl} \\
\mathrm{cpx} \\
\mathrm{ol}\end{array}$ & $\begin{array}{l}8 \\
1 \\
1\end{array}$ & $\begin{array}{l}1.59 \\
1.03 \\
0.73\end{array}$ & & & & & $89^{+}$ \\
\hline & $45-8,3-9$ & $61 \mathrm{a}$ & Tholeiite & $\begin{array}{l}\mathrm{pl} \\
\mathrm{cpx} \\
\mathrm{ol}\end{array}$ & $\begin{array}{r}3 \\
1 \\
<1\end{array}$ & $\begin{array}{l}1.29 \\
1.43 \\
0.78\end{array}$ & & & & & 96 \\
\hline & $46-3,43-51$ & $62 \mathrm{a}$ & Tholeiite & $\begin{array}{l}\mathrm{pl} \\
\mathrm{cpx} \\
\mathrm{ol}\end{array}$ & $\begin{array}{l}4 \\
1 \\
1\end{array}$ & $\begin{array}{l}1.17 \\
0.81 \\
0.74\end{array}$ & & & & & $93^{+}$ \\
\hline & $47-5,92-100$ & 64 & Tholeiite & $\begin{array}{l}\text { ol } \\
\mathrm{pl}\end{array}$ & $\begin{array}{l}2 \\
1\end{array}$ & $\begin{array}{l}1.39 \\
1.05\end{array}$ & 11 & $0.02-3.38$ & 0.71 & irregular & 97 \\
\hline
\end{tabular}


APPENDIX - Continued

\begin{tabular}{|c|c|c|c|c|c|c|}
\hline \multicolumn{5}{|c|}{ Groundmass } & \multirow[b]{2}{*}{ Alteration and Remarksb } & \multirow[b]{2}{*}{ Other Work } \\
\hline $\begin{array}{l}\text { Dominant } \\
\text { Texture }\end{array}$ & $\begin{array}{l}\text { Size Range } \\
\quad(\mathrm{mm})\end{array}$ & Minerals $\mathrm{s}^{\mathrm{a}}$ & Per cent & Opaque Minerals & & \\
\hline intergranular & $\begin{array}{ll}0.01 & -1.80 \\
0.005 & -0.50 \\
0.05 & -0.50 \\
0.01 & -0.51 \\
0.005-0.39\end{array}$ & $\begin{array}{l}\mathrm{pl} \\
\mathrm{cpx} \\
\text { ol } \\
\text { il } \\
\mathrm{mt}\end{array}$ & $\begin{array}{r}46 \\
26 \\
2 \\
2 \\
1\end{array}$ & $\begin{array}{l}\text { Skele tal timag. and elongate } \\
\text { ilmenite. Pyrite is present. }\end{array}$ & $\begin{array}{l}24 \% \text { altered. Rounded em- } \\
\text { bayed ol totally altered to } \\
\text { fibrous olive-green smectite } \\
\text { and iddingsite. Smectite has } \\
\text { basal } d=12.80 \AA \text { which ex- } \\
\text { pands to } 17.31 \AA \text { after glycol. } \\
\text { Smectite A only. }\end{array}$ & $\mathrm{X}, \mathrm{T}, \mathrm{R} 1, \mathrm{M}$ \\
\hline intergranular & $\begin{array}{ll}0.005 & -1.11 \\
0.01 & -0.50 \\
0.01 & -0.55 \\
0.01 & -0.50 \\
0.005-0.30\end{array}$ & $\begin{array}{l}\mathrm{pl} \\
\mathrm{cpx} \\
\text { il } \\
\text { ol } \\
\mathrm{mt}\end{array}$ & $\begin{array}{r}42 \\
35 \\
4 \\
2 \\
1\end{array}$ & $\begin{array}{l}\text { Equant exsolved timag. and } \\
\text { elongate ilmenite. Olivine } \\
\text { contains rare chromite. }\end{array}$ & $\begin{array}{l}12 \% \text { altered. Rounded em- } \\
\text { bayed ol totally altered to } \\
\text { bright blue-green fibrous } \\
\text { smectite and iddingsite. } \\
\text { Smectite has basal } d=12.44 \AA \\
\text { which expands to } 17.31 \AA \\
\text { after glycol. Smectite A only. }\end{array}$ & $\mathrm{X}, \mathrm{T}, \mathrm{R} 1, \mathrm{M}$ \\
\hline sub-ophitic & $\begin{array}{ll}0.01 & -1.34 \\
0.05 & -0.50 \\
0.01 & -0.90 \\
0.005 & -0.25 \\
0.05 & -0.50\end{array}$ & $\begin{array}{l}\text { pl } \\
\text { cpx } \\
\text { il } \\
\text { mt } \\
\text { ol }\end{array}$ & $\begin{array}{r}47 \\
37 \\
4 \\
3 \\
<1\end{array}$ & & $\begin{array}{l}24 \% \text { altered. Ol totally altered } \\
\text { to fibrous olive-green smectite } \\
\text { and iddingsite. Smectite has } \\
\text { basal } d=12.80 \AA \text { which expands } \\
\text { to } 17.31 \AA \text { after glycol. Smec- } \\
\text { tite } \mathrm{A} \text { only. }\end{array}$ & \\
\hline intergranular & $\begin{array}{l}0.01-1.19 \\
0.005-0.50 \\
0.01-0.35 \\
0.005-0.15 \\
0.01-0.50\end{array}$ & $\begin{array}{l}\text { pl } \\
\text { cpx } \\
\text { il } \\
\mathrm{mt} \\
\text { ol }\end{array}$ & $\begin{array}{r}53 \\
35 \\
6 \\
2 \\
1\end{array}$ & & $\begin{array}{l}23 \% \text { altered. Vesicles filled or } \\
\text { lined with fibrous yellow-brown } \\
\text { to olive-green smectite. Smec- } \\
\text { tite has basal } d=13.59 \AA \text { which } \\
\text { expands to } 17.31 \AA \text { after glycol. } \\
\text { Smectite A only. }\end{array}$ & \\
\hline intergranular & $\begin{array}{l}0.01-1.37 \\
0.005-0.50 \\
0.01-0.43 \\
0.003-0.20 \\
0.01-0.50\end{array}$ & $\begin{array}{l}\mathrm{pl} \\
\mathrm{cpx} \\
\text { il } \\
\mathrm{mt} \\
\mathrm{ol}\end{array}$ & $\begin{array}{r}50 \\
40 \\
4 \\
2 \\
1\end{array}$ & & $\begin{array}{l}22 \% \text { altered. Groundmass ol } \\
\text { totally altered to smectite, } \\
\text { celadonite, and iddingsite. } \\
\text { Smectite has basal } d=13.66 \AA \\
\text { which expands to } 17.66 \AA \\
\text { after glycol. Smectite A and } \\
\text { celadonite }(d=10.04 \AA) \text { pres- } \\
\text { ent. Hematite replaces some } \\
\text { mt. }\end{array}$ & \\
\hline intergranular & $\begin{array}{ll}0.01 & -1.30 \\
0.01 & -0.50 \\
0.02 & -0.60 \\
0.05 & -0.50 \\
0.01 & -0.25\end{array}$ & $\begin{array}{l}\mathrm{pl} \\
\mathrm{cpx} \\
\text { il } \\
\text { ol } \\
\mathrm{mt}\end{array}$ & $\begin{array}{r}48 \\
22 \\
4 \\
3 \\
2\end{array}$ & & $\begin{array}{l}\sim 15 \% \text { altered, ol totally } \\
\text { altered to olive-green smectite } \\
\text { and iddingsite. Smectite has } \\
\text { basal } d=14.72 \AA \text { which ex- } \\
\text { pands to } 16.98 \AA \text { after glycol. } \\
\text { Smectite A only. }\end{array}$ & \\
\hline intergranular & $\begin{array}{ll}0.01 & -1.25 \\
0.005-0.50 \\
0.03 & -0.50 \\
0.03 & -0.40 \\
0.005-0.12\end{array}$ & $\begin{array}{l}\mathrm{pl} \\
\mathrm{cpx} \\
\text { ol } \\
\text { il } \\
\mathrm{mt}\end{array}$ & $\begin{array}{r}58 \\
32 \\
4 \\
1 \\
1\end{array}$ & & $\begin{array}{l}23 \% \text { altered, ol totally altered } \\
\text { to smectite, celadonite, and } \\
\text { iddingsite. Smectite has basal } \\
d=14.24 \AA \text { which expands to } \\
17.31 \AA \text { after glycol. Smectite } \\
\text { A and celadonite }(d=10.04 \AA) \\
\text { present. Rare alkali feldspar in } \\
\text { groundmass. }\end{array}$ & \\
\hline intergranular & $\begin{array}{ll}0.01 & -1.03 \\
0.01 & -0.50 \\
0.06 & -0.50 \\
0.02 & -0.37 \\
0.005 & -0.20\end{array}$ & $\begin{array}{l}\mathrm{pl} \\
\mathrm{cpx} \\
\text { ol } \\
\text { il } \\
\mathrm{mt}\end{array}$ & $\begin{array}{r}56 \\
29 \\
3 \\
3 \\
2\end{array}$ & & $\begin{array}{l}30 \% \text { altered. Ol totally altered } \\
\text { to iddingsite and minor smec- } \\
\text { tite and celadonite }(d=10.04 \AA) \text {. } \\
\text { Smectite has basal } d=12.99 \AA \\
\text { which expands to } 17.31 \AA \text { after } \\
\text { glycol. Smectite A only. Alkali } \\
\text { feldspar replaces some pl cores. }\end{array}$ & \\
\hline $\begin{array}{l}\text { microlitic } \\
\text { intergranular }\end{array}$ & $\begin{array}{r}<0.001-0.13 \\
0.005-0.87 \\
<0.001-0.15 \\
<0.001-0.50 \\
0.005-0.19\end{array}$ & $\begin{array}{l}\mathrm{cpx} \\
\mathrm{pl} \\
\mathrm{mt} \\
\text { ol } \\
\text { il }\end{array}$ & $\begin{array}{c}40-45 \\
30-35 \\
7-10 \\
5-7 \\
1-2\end{array}$ & $\begin{array}{l}\text { Tiny equant exsolved timag. } \\
\text { Olivine contains rare } \\
\text { chromite. Pyrite is present. }\end{array}$ & $\begin{array}{l}20-23 \% \text { altered. Ol totally } \\
\text { altered to iddingsite. No clays } \\
\text { detected. Vesicles filled with } \\
\text { phillipsite and rare smectite. } \\
\text { Phillipsite also replaces some pl. }\end{array}$ & $\mathrm{X}, \mathrm{T}, \mathrm{R} 1, \mathrm{M}$ \\
\hline
\end{tabular}


APPENDIX - Continued

\begin{tabular}{|c|c|c|c|c|c|c|c|c|c|c|c|}
\hline \multirow[b]{2}{*}{ Hole } & \multirow[b]{2}{*}{$\begin{array}{l}\text { Core-Section, } \\
\text { Interval }(\mathrm{cm})\end{array}$} & \multirow[b]{2}{*}{$\begin{array}{l}\text { Flow } \\
\text { Unit }\end{array}$} & \multirow[b]{2}{*}{ Rock Type } & \multicolumn{3}{|c|}{ Phenocrysts \& Microphenocrysts } & \multicolumn{4}{|c|}{ Vesicles } & \multirow{2}{*}{$\begin{array}{l}\text { Groundmass } \\
\text { Per cent }\end{array}$} \\
\hline & & & & Mineral & Per cent & $\begin{array}{l}\text { Average } \\
\text { Size } \\
(\mathrm{mm})\end{array}$ & Per cent & $\begin{array}{c}\text { Size } \\
\text { Range } \\
(\mathrm{mm})\end{array}$ & $\begin{array}{c}\text { Average } \\
\text { Size } \\
(\mathrm{mm})\end{array}$ & Shape & \\
\hline \multirow[t]{2}{*}{$433 \mathrm{C}$} & $48-3,144-150$ & $65 a$ & Tholeiite & $\begin{array}{l}\text { ol } \\
\mathrm{pl}\end{array}$ & $\begin{array}{l}1 \\
1\end{array}$ & $\begin{array}{l}0.83 \\
0.69\end{array}$ & 17 & $0.41-4.05$ & 1.63 & $\begin{array}{l}\text { ovoid- } \\
\text { irregular }\end{array}$ & $97^{+}$ \\
\hline & $49-2,17-24$ & 66 & Tholeiite & $\begin{array}{l}\mathrm{pl} \\
\mathrm{ol} \\
\mathrm{cpx}\end{array}$ & $\begin{array}{l}2 \\
1 \\
1\end{array}$ & $\begin{array}{l}0.87 \\
0.76 \\
0.78\end{array}$ & & & & & 96 \\
\hline
\end{tabular}

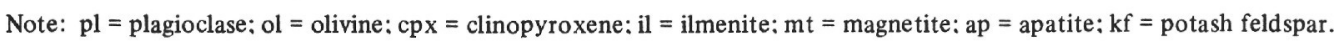

${ }^{a}$ By modal analysis of stained thin sections. Magnetite distinguished from ilmenite by shape. All percentages corrected for low-temperature alteration.

${ }^{\mathrm{b}}$ Smectite A is expandable on glycolation. Smectite B is only partially expandable on gly colation. Chlorite is not expandable.

Other Work: $\mathrm{W}=$ wet chemical analysis

$\mathrm{X}=\mathrm{X}$-ray fluorescence for majors

$\mathrm{P}=$ microprobe for majors (Bence, et al.)

$\mathrm{T}=\mathrm{X}$-ray fluorescence for trace elements

R1 = INAA for rare earths and trace elements (Clague \& Frey)

R2 = ES for rare earths and trace elements (Bence, et al.)

$\mathrm{S}=\mathrm{Sr}$ isotopic analysis (Lamphere, et al.)

$\mathrm{K}=\mathrm{K}$-Ar ages (Dalrymple et al.)

$\mathrm{M}=$ microprobe mineral analyses (Clague, et al.) 
APPENDIX - Continued

Groundmass

\begin{tabular}{|c|c|c|c|c|c|c|}
\hline \multicolumn{5}{|c|}{ Groundmass } & \multirow[b]{2}{*}{ Alteration and Remarks $b$} & \multirow[b]{2}{*}{ Other Work } \\
\hline $\begin{array}{l}\text { Dominant } \\
\text { Texture }\end{array}$ & $\begin{array}{l}\text { Size Range } \\
(\mathrm{mm})\end{array}$ & Mineralsa & Per cent & Opaque Minerals & & \\
\hline intersertal & $\begin{array}{ll}0.02 & -1.32 \\
0.02 & -1.35 \\
0.01 & -0.50 \\
0.005 & -0.05 \\
0.01 & -0.50\end{array}$ & $\begin{array}{l}\mathrm{pl} \\
\mathrm{cpx} \\
\mathrm{ol} \\
\mathrm{mt} \\
\mathrm{il}\end{array}$ & $\begin{array}{r}51 \\
32 \\
11 \\
2 \\
1\end{array}$ & & $\begin{array}{l}24 \% \text { altered. O1 totally altered } \\
\text { to iddingsite and smectite. } \\
\text { Smectite has basal } d=13.38 \AA \\
\text { that expands to } 17.31 \AA \text { after } \\
\text { glycol. Smectite A only. Vesi- } \\
\text { cles lined with pale yellow- } \\
\text { green fibrous smectite. Much } \\
\text { of the groundmass stains } \\
\text { yellow with sodium cobalt- } \\
\text { nitrite. }\end{array}$ & \\
\hline intersertal & $\begin{array}{c}0.02-1.20 \\
0.02-0.50 \\
0.01-0.50 \\
0.01-0.85 \\
0.005-0.55 \\
-\end{array}$ & $\begin{array}{l}\text { pl } \\
\mathrm{cpx} \\
\text { ol } \\
\text { il } \\
\mathrm{mt} \\
\mathrm{kf}\end{array}$ & $\begin{array}{r}60 \\
17 \\
12 \\
6 \\
1 \\
1\end{array}$ & $\begin{array}{l}\text { Equant rarely exsolved } \\
\text { timag. and elongate } \\
\text { ilmenite. Olivine contains } \\
\text { rare chromite. Pyrite is } \\
\text { present. }\end{array}$ & $\begin{array}{l}\sim 27 \% \text { altered. Ol totally } \\
\text { altered to iddingsite and smec- } \\
\text { tite. Smectite has basal } d= \\
12.62 \AA \text { which expands to } \\
17.31 \AA \text { after gly col. Many pl } \\
\text { cores replaced by kf. Phillip- } \\
\text { site and amphibole(?) after } \\
\text { clinopyroxene are also present. }\end{array}$ & $\mathrm{X}, \mathrm{T}, \mathrm{R} 1, \mathrm{M}$ \\
\hline
\end{tabular}

